Universidade de Brasília

Instituto de Letras

Departamento de Teoria Literária e Literaturas

Programa de Pós-Graduação em Literatura

Por afetos e leituras
transbordantes:

Os limites da coleção Amores Extremos

ALINE PAIVA DE LUCENA

Orientadora: Prof. ${ }^{a}$ Dr. ${ }^{a}$ Virgínia Maria Vasconcelos Leal 


\section{Por afetos e leikuras transbordantes:}

Os limites da coleção Amores Extremos

Dissertação apresentada ao Departamento de Teoria Literária e Literaturas da Universidade de Brasília como requisito parcial para obtenção do título de mestre em Literatura.

Orientadora: Virgínia Maria Vasconcelos Leal

Linha de pesquisa: Representação na Literatura Brasileira Contemporânea 


\title{
Por afetos e leituras transbordantes: Os limites da coleção Amores Extremos
}

\author{
Banca Examinadora
}

Prof. ${ }^{a}$ Dr. ${ }^{a}$ Virgínia Maria Vasconcelos Leal (presidenta)

Prof. ${ }^{a}$ Dr. ${ }^{a}$ Edma Cristina Alencar de Góis (URCA) (membro)

Prof. ${ }^{a}$ Dr. ${ }^{a}$ Regina Dalcastagnè (TEL/ UnB)
(membro)

Prof. Dr. Anderson Luís Nunes da Mata (TEL/ UnB)

(suplente) 


\section{Agradecimentos}

Aos professores e professoras que fizeram da minha trajetória possível, em especial e com muito carinho, à minha orientadora, Virgínia Leal, que me acolheu e se fez presente em cada etapa desse percurso, sempre com muito zelo e dedicação e a todo momento me incentivou e encorajou.

Às amigas/professoras, Ria e Fanka, responsáveis, em grande parte, pelo nascimento desta dissertação, muito obrigada pelas conversas e experiências engrandecedoras a que me proporcionaram.

Ao Grupo de Estudos em Literatura Brasileira Contemporânea (GELBC), pelas trocas inestimáveis.

Aos meus queridos amigos, Álvaro, pelo amor e ligações intermináveis, e Ralph, companheiro de aventuras e desventuras na difícil tarefa de ser jovem e adulto.

À minha amiga, Estela, com quem partilho agonias e ansiedades há quase dez anos.

E, claro, à minha pequena família de mulheres, especialmente à minha mãe, Madalena, pelo amor desmedido e dedicação incansável durante todos esses anos, e de forma igualmente especial, à orientadora da minha vida, minha irmã, Bruna, que sempre apoiou minhas escolhas e segue cotidianamente me encorajando. 


\section{Resumo}

Esta dissertação analisa a representação do gênero, do corpo e das relações amorosas na coleção Amores Extremos, da editora Record, publicada entre os anos de 2001 e 2003, e composta por sete romances de escritoras brasileiras. A partir da análise do formato de coleção no campo literário, são feitas problematizações a respeito do projeto editorial, pautado nos recortes de autoria feminina e temática amorosa. Como projeto editorial, são analisadas, além das narrativas, as capas de cada romance. O presente estudo busca, a partir de estudos de gênero e teorias feministas, desmembrar o jogo que torna viável a coleção e a ideia de feminino nela inserida.

Palavras-chave: representação, gênero, coleção Amores Extremos, capas, corpo, amor. 


\begin{abstract}
This paper analyses the representation of gender, body and love relationships in Amores Extremos collection, from Record publisher, published between the years of 2001 and 2003, composed by seven novels of Brazilian writers. Starting from the collection's literary gender some questions were raised concerning the book project, which is based on female authorship focus and in the love thematic. As a publishing project, besides the narratives, also the book covers of each novel are being analyzed. The present work, grounded on gender studies and feminist theories, intends to investigate the scheme that makes this collection possible and the idea of feminism inserted in it.
\end{abstract}

Keywords: representation, gender, Amores Extremos, collection, covers, body, love. 


\section{Sumário}

Introdução 1

\section{Capítulo I}

1.1 Do volumen à brochura .................................................................. 4

1.2 Livro, textos e paratextos ........................................................ 7

1.3 Capa: muito além da proteção .................................................... 10

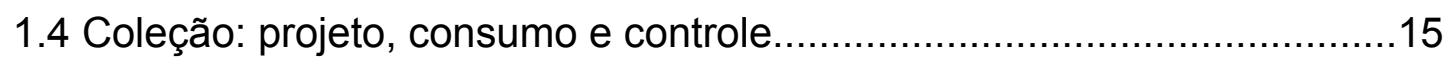

1.5 Autoria feminina: a dúvida que nos quer calar...................................18

1.5.1 Corpo, identidade e ordem discursiva............................... 22

1.5.2 Mulher e literatura: aproximações e implicações..................... 28

\section{Capítulo II}

2.1 As extremidades do amor ........................................................ 34

2.2 O amor como dispositivo ........................................................ 39

2.3 Amor e romantismo .................................................................. 43

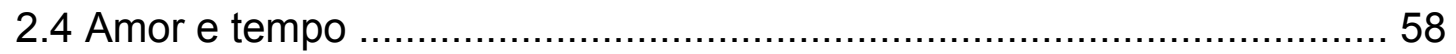

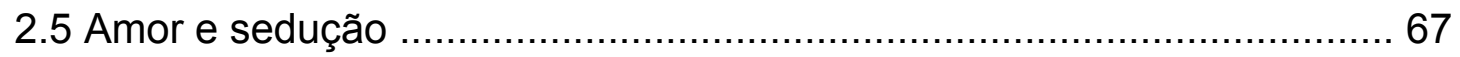

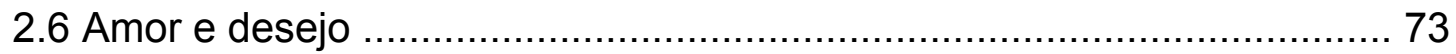

Capítulo III

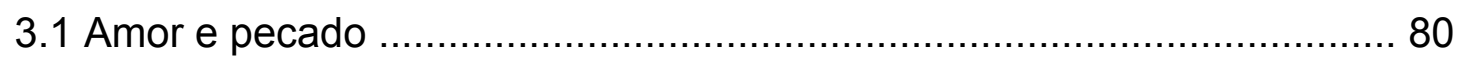

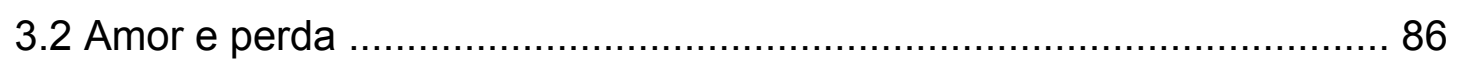

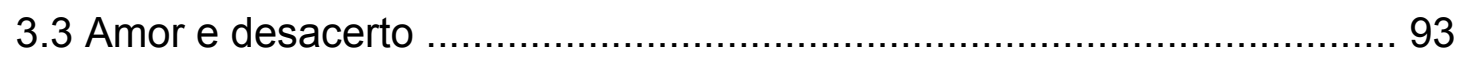

Certezas provisórias _ـ 101 


\section{Introdução}

Tema cada vez mais presente e debatido nos estudos feministas e de gênero, o corpo, como um local no qual imposições são refletidas e muitas vezes justificadas, sempre me pareceu terreno bastante frutífero no estudo das representações na literatura. Por acreditar que o corpo me daria evidências das possibilidades de gênero veiculadas por cada escritora, estudá-lo foi meu primeiro lampejo na análise da coleção Amores Extremos, objeto de estudo desta dissertação. Pautada nos recortes de autoria feminina e temática amorosa, a coleção movimenta, já em sua proposta, questões importantes para se pensar a representação dos corpos femininos. Mas, se inicialmente, instigada pela promessa-chave da coleção, ambicionei encontrar, conjuntamente aos amores descomedidos e variados, diferentes configurações corporais, quando parti para uma leitura empenhada e atenta das obras da coleção, o corpo me escapou.

Ao esperar que as relações amorosas delineassem os corpos femininos ali representados, fui surpreendida por narrativas em que esses apareciam soterrados por essas relações. Secundário, ou mesmo excluído, o corpo já não se constituía aspecto tão profícuo na representação das mulheres. Ao passo que, individualmente, as obras mostraram-se, muitas vezes, indiferentes a esse corpo, outros aspectos ganharam força e presença na minha investigação. Escrita a partir de recortes, que quando somados, enchem-se de implicações, o estudo da coleção parecia precisar não de mais um recorte, como eu inicialmente propunha, ao fazer do corpo meu guia de análise, mas antes uma visão que ultrapassasse suas barreiras e limites que permitisse ver mais que representações isoladas, detectar um projeto pensado e articulado a partir de bases e demandas específicas.

$\mathrm{Na}$ expansão desse olhar, ultrapassei o corpo do texto e fiz das capas, assim como as narrativas, objeto de análise. Como elemento de conexão e identificação das obras da coleção, elas aparecem em meu estudo como um importante suporte de análise. Por essa razão, no Capítulo 1 , busco demonstrar o peso que os suportes sempre tiveram na criação de um livro, como afetaram e afetam sua produção e consumo. Como uma dimensão bastante significativa trago estudos de teóricos como Pierre Lévy, 
Roger Chartier e Dominique Maingueneau, que propõem o resgate desse suporte na construção de qualquer conhecimento por ele viabilizado. Levanto ainda, algumas hipóteses da desconsideração frequente do suporte nos estudos literários.

O suporte envolvendo ainda muitas partes, faço uso da teoria dos paratextos de Gérard Genette, e é como tal que penso e estudo as capas das narrativas da coleção. Como ferramentas organizadoras, os paratextos funcionariam para além de uma ordenação simplória, ao sistematizar uma ordem, carregariam um potencial controle de sua recepção e interpretação. Manipulados por agentes do campo literário, os paratextos seriam assim uma forma de fixar sentidos; numa coleção, que por definição tem em seu suporte função de identificação e conexão entre suas obras, seu estudo e análise tornam-se emergentes para quem, como eu, pretende enxergar além das narrativas que a compõem, o projeto por trás da coleção que as envolve.

As capas que, na coleção, são todas ilustradas por obras de pintores homens, já consagrados, aparecem em minha análise, como mais um indício das intenções manejadas na construção da coleção Amores Extremos, que ao juntar recortes como o amor e a autoria feminina, movimenta inevitavelmente uma série de pressupostos e discursos. Como um formato nada inédito, a coleção também é explorada no Capítulo I, relembro sobretudo a importância das coleções recortadas pelo critério do gênero, que desde os primórdios segmentou públicos e direcionou temas e leituras.

Aspecto de variadas significações, que vão desde a existência de uma possível escrita e estética femininas até à existência de um projeto maior, como uma literatura de mulheres, a autoria feminina, tema muitas vezes tomado de maneira genérica e auto-explicativo, é igualmente discutida no primeiro capítulo. Problematizando essas duas principais teorias e retomando noções importantes, como corpo e experiência, procurei antes investigar todo jogo e implicações que automaticamente se armam ao redor de um livro que tem um nome de mulher na capa. Nesse capítulo, teóricas do gênero e do feminismo foram importantes para essa análise, como Teresa de Lauretis, Susana Funck, Iris Young e Judith Butler.

Segundo recorte de peso e de múltiplas indagações é o amor o tema central do segundo capítulo. Tópico frequente e de aparência pouco político- 
ideológica, o amor, ao aparecer circunscrito pela autoria feminina, ganha, numa leitura empenhada, contornos importantes e controversos. Busquei levantar no presente capítulo os melindres cunhados pelo e em nome do amor, que por muito tempo se manteve longe de lentes críticas e, por essa mesma razão, tornou-se instrumento forte e eficaz, sendo elemento decisivo na instituição do casamento e do modelo nuclear-burguês de família. Tomado nos termos de Michel Foucault, o amor é aqui visto como um dispositivo de extrema relevância e eficácia na implementação e manutenção dos papéis de gênero. Assim, retomo as ideias do filósofo acrescidas, principalmente, de estudos posteriores de Tânia Navarro-Swain (2013) e Claudia Maia (2011), já em um contexto brasileiro. Ainda no segundo capítulo inicio a análise das narrativas, numa ordem que pretende ir das obras que apresentam narrativas mais tradicionais, em relação aos papeis de gênero, para aquelas que de alguma forma escapam ou desafiam determinadas prescrições normatizadoras. Ainda neste capítulo, trago aquelas que se mantém presas a um ideal de feminino e a concepções de amor que têm na estrutura binária entre os sexos sua organização e funcionamento.

No terceiro e último capítulo, são as narrativas que incitam de alguma forma desconformidades ao modelo tradicional de representação de mulheres e amores, que são analisadas. Ao final de cada uma das sete narrativas analiso, a partir delas, suas capas, buscando elementos de conexão ou mesmo disparidades.

Enfim, ao analisar a coleção Amores Extremos, composta por obras de sete escritoras relativamente experientes, no sentido de não serem estreantes no campo literário, deparei-me com mais repetições e limites do que com representações que transbordassem, em alguma medida, moldes tradicionais. 


\section{Capítulo I}

\subsection{Do volumen à brochura}

Do volumen à brochura, o percurso do livro foi atravessado por inovações que o alteraram de forma decisiva. Dessas, a imprensa de Gutenberg, datada do ano de 1430, talvez tenha sido a mais revolucionária, pois transformou, de maneira vertiginosa, diferentes âmbitos que envolviam o livro, que passou a ser um objeto, mais que produzido, fabricado em larga escala. Tal mudança alterou de forma significativa a forma de se ler e deu à relação entre forma e conteúdo novos contornos, mas não menos desconforto, uma vez que, como um produto, que seria comercializado, o livro circularia, agora, pela mais dura das realidades, a do dinheiro.

Mesmo o suporte possuindo um papel fundamental no desenvolvimento do livro, por muito tempo, buscou-se, quando não ignorar as conexões desse com o que havia de concreto em sua história, separar os estudos das técnicas e materiais dos estudos do conteúdo propriamente dito. Toda essa resistência está muito arraigada ao pensamento poético e filosófico de que a matéria corromperia a pureza da ideia, como bem explica o teórico Roger Chartier (1994), o que alimentou e salvaguardou uma relação de natureza quase mística não só com o livro mas, de um modo geral, com a arte, que sempre manteve uma relação complexa com tudo que advém da realidade, sendo constantemente isolada não só das práticas materiais como também das relações sociais com as quais inevitavelmente convive.

Pensadores, como Pierre Lévy (1993), Roger Chartier (1994) e Dominique Maingueneau (2001), são alguns dos nomes que posicionaramse contra a tentativa de invisibilizar o suporte e propuseram, a partir de perspectivas diversas, mais do que sua visibilidade, o resgate de seu papel, incontestável, na história. Nesse ponto, Pierre Lévy não se restringe ao livro ou à literatura, mas expande esse pensamento à própria história do saber, dado que as maneiras de pensar, para ele, estão sempre condicionadas aos processos materiais, que se desenvolvem e se metamorfoseiam de forma 
recíproca e decisiva, o que atribui à técnica o poder de incidir de forma significativa sobre os mais variados aspectos da vida social, o que nas palavras de Lévy, faz da técnica "um dos mais importantes temas filosóficos e políticos de nosso tempo" (LÉVY, 1993, p. 7). Se antes ela aparecia como pano de fundo de grandes transformações político-científicas, hoje já se pode falar em cena das mídias (LÉVY, 1993, p. 8), no qual o fazer ocupa uma dimensão que requer cada vez mais atenção.

Reiterando o posicionamento de Pierre Lévy, mas sob uma perspectiva histórica, temos Roger Chartier, que fez da história da leitura e da escrita sua perspectiva de análise. O historiador chama atenção à dupla historicidade do escrito, uma vez que, diante da tentativa de abstração do texto, seria necessário rever toda a trajetória da escrita, rearticulando-a ao seu suporte:

[...] é preciso trazer toda produção escrita, seja qual for seu gênero ou estatuto, às categorias de citação, de designação e de classificação de acordo com o tempo e o lugar que lhes são próprios e, ao mesmo tempo, às formas materiais de sua inscrição e sua transmissão (CHARTIER, 2002, p. 64)

Linguista, Dominique Maingueneau (2001) segue esse mesmo caminho em $O$ contexto da obra literária, apresenta-nos o suporte material como um dos contextos em que a obra literária está inserida e sem o qual não pode ser compreendida em sua integridade, e propõe o resgate da dimensão midiológica das obras, que seria o restauro de todas as mediações materiais que as circunscrevem, compreendendo estas como partes constituintes e significativas de sua composição, rematerializando, assim, mais do que propriamente textos, seus discursos.

Resgatar o suporte dentro da história do livro e da literatura é encarálo também como mercadoria, expondo, assim, o capítulo mais controverso de suas formações. Mesmo sendo figura não grata em boa parte dos estudos literários e do livro, o suporte não é só parte integrante como significativa dos textos que porta, ou mesmo uma prerrogativa, uma vez que obras só existem quando se tornam realidades físicas. Porém, a grande questão posta no retorno ao suporte são os efeitos e possibilidades que carrega. 
O livro não nos chega como um texto abstrato, dotado de imaterialidade, declarado apenas por si mesmo. No formato, instaurado na modernidade e em vigor até os dias de hoje, ele apresenta e é apresentado por capas, epígrafes, nomes de autores e autoras, títulos, ilustrações, dimensões; aspectos esses que não só organizam e definem o objeto livro, controlam sua recepção e interpretação, como também afetam diretamente na forma como são consumidos. Se inicialmente os livros tinham de ser lidos em voz alta graças às suas dimensões gigantescas, e ao número irrisório de pessoas alfabetizadas, depois dos tipos móveis de Gutenberg, no mundo eurocêntrico, a leitura passou a ser um gesto ágil, individual e silencioso, o que para teóricos como Roger Chartier (1994), nos distanciou do texto ao modificar o uso do corpo na leitura, agora não mais em voz alta; o que não deixa de ser mais um vínculo com a realidade a ser evitado, fato que parece ter se intensificado quando pensamos que novas tecnologias, como ereaders, nos privam do contato direto com o papel no passar das páginas.

Antes de as formas pretenderem controlar nosso manuseio e interpretação, essas, como mecanismos de relação direta com o texto, são manuseadas por seus autores e autoras e/ou editores e editoras visando determinados efeitos, que podem ser diversos, mas que possuem um objetivo em comum: o controle. Fixar um sentido é ato inerente do processo de criação, e mesmo a literatura que se desenvolve em grande parte sob a égide da flexibilidade de suas interpretações, no próprio fazer literário, nas escolhas que o envolvem há uma imposição de limites à leitura, ao olhar, que cerceiam possibilidades e constrangem interpretações.

O suporte, ao remeter necessariamente ao controle instaurado e exercido sob o livro foi tornado secundário, e ao perder presença nos estudos literários, amplificou seu uso. Porém a desconsideração do suporte tinha destinatários específicos, para aqueles que já se dividiam entre o mundo literário e econômico, para quem o livro era, até antes mesmo de escrito, uma mercadoria, o suporte era não apenas um dispositivo, era um aliado. A figura do editor é uma peça-chave para o desenvolvimento e refinamento do suporte e, principalmente, de seus efeitos. Ela aparece como a engrenagem responsável por, mais que selecionar, como bem afirma Chartier (2002, p. 76), "domesticar a abundância" propiciada pelas novas 
tecnologias da época. Domesticar torna-se palavra bastante adequada quando recordamos que a atividade editorial aos poucos mais do que selecionar o que seria ou não publicado, o que já é uma tarefa de grande dimensão e impacto, influenciou diretamente na forma e na ordem dos livros.

Roger Chartier (1994) afirma que o livro sempre buscou instaurar uma ordem, "fosse a ordem de sua decifração, a ordem no interior da qual ele deve ser compreendido ou ainda, a ordem desejada pela autoridade que o encomendou ou permitiu a sua publicação" (CHARTIER, 1994, p. 8). Assim, capas, contracapas, prefácios, são todos elementos organizados, trabalhados e aperfeiçoados como recursos de prescrição do caminho a ser seguido, logo da compreensão a ser alcançada. Porém, o leitor/leitora, parte fundamental da existência de um livro, carrega em si um potencial de autonomia, podendo não só acatar a proposição que lhe é oferecida mas igualmente deslocá-la, reformulando suas configurações e sentidos.

\subsection{Livro, textos e paratextos}

Quando Roger Chartier (1994) afirma que autores e autoras não escrevem livros, mas textos, deixa clara a condição de artefato do livro, dado que livros não são literalmente escritos, são, desde antes da invenção das prensas, por copistas ou outros artífices, fabricados. Seguindo esse mesmo pensamento, o que chega até nós, leitores e leitoras, não são textos, são objetos, envolvidos numa capa, individualizados por um título, identificados por um nome de autor ou autora, informações que podem, algumas vezes, nem ser consideradas na leitura, e outras, funcionar como elemento preponderante na escolha, classificação e valoração de uma obra. Mas, uma vez que são pensadas a partir e como prolongamentos do texto, enxergar uma obra literária também sob aspectos técnicos e visuais é desvendar o quão das intenções encontradas no corpo do livro são realmente cerceadas ou ampliadas por eles.

No estudo desses elementos, o teórico Gérard Genette (2009), assim como Chartier, difere livro de texto, enxergando este como um estado mínimo da obra, e aquele como o texto já cercado de reforços que lhe garantem materialidade, presença e inteligibilidade; Genette chama todas 
essas extensões de paratextos. Conceito este por ele arquitetado e que, conjuntamente a outros quatro - intertextualidade, metatextualidade, hipertextualidade e arquitextualidade - estruturam o que ele denomina de transcendência textual ${ }^{1}$. O texto é sempre um intertexto (FAIRCLOUGH, 2008), dado que, continuadamente, responde e/ou se baseia em outros textos, o que caberia a nós, leitores e leitoras, seria decifrar a rede de relações que o tecem. Dessa forma, a paratextualidade, para Genette, é uma dessas relações, e diz respeito especificamente à forma pela qual um texto torna-se um livro.

A escolha do termo "paratextualidade" deve-se ao significado contido no prefixo para, que traz, de forma concomitante, as ideias de proximidade e distância, de semelhança e diferença, sendo o paratexto, antes de uma fronteira, uma zona de possibilidade, com a qual leitores/leitoras, autores/autoras e inevitavelmente editores/editoras têm de lidar.

Mais que um limite ou uma fronteira estanque, trata-se aqui de um limiar, [...] um 'vestíbulo', que oferece a cada um a possibilidade de entrar, ou de retroceder. 'Zona indecisa' entre o dentro e o fora, sem limite rigoroso, nem para o interior (o texto) nem para o exterior (o discurso do mundo sobre o texto. [...] constitui entre o texto e o extratexto uma zona não apenas de transição, mas também de transação: lugar privilegiado de uma pragmática e de uma estratégia, de uma ação sobre o público, a serviço, bem ou mal compreendido e acabado, de uma melhor acolhida do texto e de uma leitura mais pertinente - mais pertinente, entenda-se aos olhos do autor e seus aliados. (GENETTE, 2009, p. 9-10)

Ainda dentro do paratexto, o teórico francês o subdivide em duas partes, peritexto e epitexto, com o intuito de separar os aspectos relacionados à categorial espacial, que seriam capas, títulos, ilustrações, nome do autor (peritexto) e os responsáveis pela parte mais externa ao livro, como entrevistas, debates, resenhas (epitexto). O peritexto, ao responder diretamente ao objeto livro, está, em grande parte, mas não unicamente, sob tutela das casas editoriais, comandadas por editores e editoras, que são, de

\footnotetext{
${ }^{1}$ Para Gérard Genette a transcedência textual é alcançada por meio de cinco possíveis relações textuais, fora a já mencionada paratextualidade, o crítico literário traz outras quatro: a intertextualidade, que indicaria a co-presença de dois ou mais textos; a metatextualidade que seria a relação que une um texto a outro, do qual ele exprime um comentário; a hipertextualidade que definiria a relação que une um determinado texto a outro que proveria desse mesmo texto e por fim, a arquitextualidade que determinaria o gênero em que o texto é classificado por seus leitores.
} 
acordo com o Pierre Bourdieu (1996), um dos principais agentes do campo literário, razão pela qual investigar tal paratexto revela escolhas que ultrapassam questões gráficas e estéticas.

As alterações formais por quais o livro passou não se limitaram às capas, contracapas e orelhas, acarretaram mudanças de ordem social e econômica e editores e editoras foram peças fundamentais na instauração e implementação dessas. Responsáveis por selecionar o que seria ou não publicado, - por possuírem dinheiro ou influência, ou ainda os dois - a partir de dois principais critérios de hierarquização, o da arte comercial, que obedece a demandas mercantis e $\mathrm{o}$ da arte pela arte, que nega essas mesmas demandas, e aparece em defesa da arte pura, livre de pressões e interesses terceiros; editores/ editoras e suas casas editoriais, ao manipularem não apenas o texto, mas também, ou principalmente o objeto livro, circulam e lidam igualmente por e com esses dois pólos.

Todavia, editores e editoras são apenas um dos inúmeros e complexos agentes que compõem um campo que ainda responde e influencia vários outros. Num jogo de regras muito específicas, em que cada agente busca defender seus interesses, o campo, definido de uma forma geral como uma "rede de relações objetivas (de dominação ou de subordinação, de complementaridade ou de antagonismo etc) entre posições" (BOURDIEU, 1996, p. 262), forma-se não só da relação desses agentes, mas antes de suas oposições. Em suas diferenças eles demarcam posições, que não são fixas, como um sistema aberto que é, o campo literário está em permanente revolvimento, não obstante suas possíveis mudanças sejam por ele mesmo antevistas e quando oportuno, acatadas.

O campo literário, formado por inúmeros agentes em diferentes disposições e em defesa de perspectivas ideológicas que funcionam como demarcadores de espaço e identificação da posição que determinado agente ocupa, permite analisar obras que são engendradas a partir das relações ali estruturadas e desmembrar conexões e enxergar interesses que resguardam sua publicação, que estipulam sua importância e que garantem, ou não, sua longevidade dentro do campo, e que são frequentemente reiterados pelos elementos que vestem a narrativa com informações que 
além de informar, norteiam interpretações e valorações acerca do livro e de quem o produziu.

\subsection{Capa: muito além da proteção}

Dos paratextos que envolvem um livro, a capa talvez seja o mais emblemático e de mais fácil percepção do livro na qualidade de produto, que como tal, possui uma embalagem, explicação que justificaria a razão da pouca atenção na análise da capa dentro dos estudos literários, estando, ainda hoje, em sua maioria, restrita à área da comunicação.

Pensada inicialmente como um elemento de proteção, a capa vem acumulando finalidades. Proteger, informar, legitimar o valor de um livro, são algumas das funções da capa, que vem se reinventando como suporte e ganhando cada vez mais atenção. Imaginada a partir do texto ou como um elemento de caráter publicitário, a capa reflete um conjunto de escolhas e de decisões e por essa razão torna-se aspecto frutífero quando busca-se pensar a literatura para além dos limites das páginas.

A capa passou por um longo percurso até alcançar o status e a configuração que possui hoje. Até fins do século XVIII, os livros saíam de gráficas sem nenhum tipo de revestimento, sendo encadernados por casas e profissionais especializados, muitas vezes contratados pelos próprios compradores, que, a depender da quantia que estivessem dispostos a pagar, disporiam de uma encadernação já pronta ou ainda de um trabalho feito sob medida, o que fazia da capa um elemento que, ao encobrir o livro, expunha o status de seu comprador. Mas contrário ao ocorrido com a disposição o corpo do livro, que pouco alterou-se desde a invenção do códex (formato do livro como conhecemos hoje, com folhas e páginas), sendo continuadamente visto como a essência de uma obra, a capa teve seu papel revisto e resignificado em diferentes momentos da história do livro.

Com o aumento do público leitor, incitado por inúmeros fatores, como a grande circulação de jornais e a ampliação do número de pessoas 
alfabetizadas, em especial das mulheres ${ }^{2}$, o livro, antes um artefato manufaturado, às vezes personalizado, passa a ser um objeto impessoal, de rápida e fácil reprodução; a eficiência da produção e a qualidade gráfica, agora pontos cruciais na produção de um livro, acarretaram mudanças que atingem forma e conteúdo, porém das partes que compõem um livro, capa e miolo, desde as suas criações, sempre possuíram tratamentos diferenciados ou mesmo apartados um do outro.

A fragmentação da produção, comum em todo tipo de fabricação seriada, só reforçou uma divisão muito antiga existente entre capa e miolo. A capa, mesmo superado seu caráter exclusivo de elemento protetor, continuou a ser pensada e projetada como elemento exterior, autônomo, a parte do conteúdo, ao ponto de possuir um profissional dedicado tão somente a ela. A função de produtor gráfico emerge da relevância publicitária que a capa adquire, informativa e anunciante, ao ponto de hoje ser uma categoria do Jabuti, prêmio literário de maior relevância no Brasil, dado pela Câmara Brasileira do Livro. Mais que proteger ela passa a ser um veículo de calibre estético e comercial que, por meio de imagens e tipos, traduziriam não necessariamente um assunto, mas antes uma intenção projetada para determinados efeitos.

Entretanto, os investimentos dedicados à capa deram-se de forma conturbada. Trabalhoso e dispendioso o investimento na capa era visto como algo desimportante, superficial diante do imperioso conteúdo, ao ponto de um livro que dispusesse de muitos artifícios estéticos, como bordas e ilustrações, ser considerado de menor valor literário, uma vez que esses artifícios atrairiam leitores incultos, como se capas muito trabalhadas degradassem conteúdos ou tentassem compensar, como um recurso de dispersão, livros de pouca importância. Essa visão também foi bastante alimentada pelo fato de a ilustração surgir inicialmente associada às crianças, como bem aponta Allan Powers (2008), em sua obra Era uma vez uma capa, em que discorre sobre a trajetória das capas com foco nos livros infantis, nos quais as ilustrações, diferentemente do que ocorre na dita

\footnotetext{
${ }^{2} \mathrm{O}$ acesso à educação e à alfabetização foi uma das primeiras reivindicações feitas pelo movimento de mulheres na luta pela igualdade de direitos.
} 
"Grande Literatura", conquistaram espaço e importância não só na arte da capa como na construção do próprio texto. Em contrapartida a tal aspecto editoras como Cosac Naif, fazem do investimento na capa uma de suas marcas e distinções no mercado editorial. E outras como Companhia das Letras vêm despendiando cada vez mais investimentos em tipos e gramaturas de papeis e design de logotipos. E contracorrente ao processo de produção e reprodução em larga escala, há uma nova tendência editorial que faz da produção artesanal de um livro sua marca, as chamadas cartoneras.

Porém, o ponto mais nevrálgico quando o assunto em questão é a capa seja talvez sua função publicitária. Como um peritexto, que evidencia, no próprio corpo do livro, o processo externo de produção da indústria editorial, a capa é o inegável prenúncio do livro como objeto de caráter e valor econômicos, entretanto, sabemos que o livro responde a vicissitudes que ultrapassam sua linha de produção; sua fabricação e publicação sendo regidas e estruturadas a partir de leis muito específicas, nem sempre só de ordem monetária, como já apontado anteriormente pela teoria do campo literário de Bourdieu.

Ao olhar retrospectivamente para a história do livro, pode-se enxergar as grandes mudanças pelas quais ele perpassou, e a dimensão gigantesca que o espantoso progresso das técnicas de produção e distribuição atingiram, ao ponto de tais avanços serem medidos e analisados na proporção de uma revolução, como defende Robert Escarpit (1976), uma vez que as consequências dessas transformações não se mantiveram restritas ao âmbito editorial, mas ultrapassaram páginas e prateleiras e fizeram do livro, assim como a imprensa, o rádio e o cinema um grande veículo de informação.

A despeito de sua condição de artefato, o livro não é um objeto como outros, partilha, em sua própria condição física, aspectos, que são interligados, dependentes, porém constantemente afastados um do outro. Conjugando aspectos textuais, estéticos e econômicos, a produção de um livro se dá tendo como pano de fundo um sistema que influencia e é influenciado por esses, entre outros, aspectos. A capa, como emblema do objeto livro, de claras intenções publicitárias mostrou-se como grande aliada 
no consumo desse, não apenas no sentido mercantil, mas no próprio consumo do texto. Como um elemento que circunda o texto física e metaforicamente, a capa, na qualidade de paratexto, ou mais especificamente peritexto, oferece possibilidades, sugere interpretações, influencia escolhas e, acima de tudo, revela um projeto.

Os paratextos, em seu formato atual, como mediadores diretos entre autor/autora, editor/ editora e leitor/ leitora, são espaços de intervenção profícuos na elaboração e concretização de uma obra, uma vez que a forma como um texto é vestido visualmente torna-se fundamental no processo de construção de seu significado. Dessa forma, estabelecer uma relação entre imagens e tipos que ilustram capas de livros com os conteúdos que esses carregam tornou-se atividade de grande importância, ou quando não for possível, nos indagarmos das possíveis razões para tal falta de conexão entre as partes. Diante do exposto, vale a pena discorrer sobre o caso brasileiro, tendo em vista o corpus desta dissertação.

No Brasil, Monteiro Lobato foi um dos grandes responsáveis por modernizar e investir na indústria gráfica brasileira, que se encontrava obsoleta e presa aos padrões franceses. Conjuntamente a Octalles Marcondes Ferreira, Lobato, na época, à frente da Companhia Editorial Nacional, planejou sua própria oficina gráfica, importou novos tipos dos Estados Unidos, e compreendendo que era preciso melhorar a qualidade e aparência do livro como um todo, investiu na qualidade do papel, introduziu um padrão próprio (16,5 x 12,0cm), contratou novos artistas, abusou de cores fortes e berrantes nas capas, que agora também possuíam figuras, instaurando, assim, uma verdadeira revolução gráfica do livro brasileiro e rompendo de vez com o padrão francês ainda incrustado na produção editorial feita no Brasil até a década de 1920.

As modificações trazidas e instauradas por Monteiro Lobato só se tornaram possíveis graças a sua visão empreendedora, ao enxergar o livro como um produto que deveria ser vendido como sabão, como nos conta Laurence Hallewell (1985), logo devendo ser igualmente anunciado. Consciente do valor publicitário contido num livro, Lobato percebeu que o antigo boca-a-boca, do qual o livreiro era uma figura de grande importância, além de já não ser suficiente, perto das potencialidades que a edição de um 
livro possuía, a recomendação do vendedor de livros parecia muito aquém das possibilidades e alcance portados agora pelo próprio objeto livro.

De iniciativas como substituição do papel e alteração de cores e formato, Monteiro Lobato revolucionou não apenas aspectos físicos, mas a forma de administrar o negócio como um todo; e ao enxergar o ato de editar com uma forma de "fazer psicologia comercial" (HALLEWELL, 1985, p. 251) deu início a um progresso ininterrupto da indústria editorial no Brasil. Ênio Silveira, genro do editor aqui já mencionado, Octalles Marcondes Ferreira, também é um dos grandes nomes da história do livro brasileiro, considerado um editor de vanguarda, foi o responsável por repaginar a imagem da editora Civilização Brasileira, na década de 1960 e investir fortemente no setor publicitário numa época em que cerca de $40 \%$ das editoras brasileiras não possuíam verba destinada para publicidade, foi ele o responsável pela contratação de Eugênio Hirsch, como bem conta Hallewell (1985, p. 187).

Artista plástico, Hirsch foi contratado por Ênio Silveira com intuito de renovar a imagem dos livros e da própria editora (Civilização Brasileira), que buscou estabelecer uma nova identidade visual por meio da reformulação estética de sua produção editorial, que passa a apresentar ilustrações e gravuras em quatro cores, que ocupam toda a altura e largura da capa, com inclusão da lombada, e sempre acompanhadas do registro de crédito do artista responsável. De proporções assimétricas e cores fortes, as capas de Eugênio Hirsch eram, como ele mesmo afirmava, feitas para agredir e não para agradar.

Artista multifacetado e com carta branca de Ênio Silveira para efetuar mudanças, Hirsch manipulava diferentes tipos de técnicas e materiais; de estilo agressivo, distorceu por completo o espaço da capa, criou leiautes que fugiam da lógica central e vertical e ao integrar aspectos verbais e visuais em diferentes disposições e hierarquias deu um aspecto moderno ao livro brasileiro, colaborações que fizeram dele um nome de peso na implementação e no desenvolvimento do design gráfico brasileiro, até então quase inexistente, uma vez que as capas, mesmo já munidas de sua função publicitária, permaneciam pensadas e produzidas como um elemento externo, vazios de conceito e pouco ou nada articulado ao texto. Victor Burton é outro grande nome no cenário editorial brasileiro, designer a frente 
da Nova Fronteira, repaginou padrões de projetos gráficos que desde Hirsch não sofriam grandes transformações, redefinindo de forma contundente o mercado editorial brasileiro nos anos 1980.

Com o aumento do número de universitários, entre os anos de 1955 e 1962, logo da procura de exemplares, editoras viram-se obrigadas a não apenas aumentar a quantidade de sua produção, como investir na variabilidade dos gêneros e em aspectos que diferenciassem seu produto. Dessa necessidade mercadológica, surge o interesse e o investimento na qualidade gráfica e plástica dos livros. Monteiro Lobato já tinha iniciado essa revolução no mercado editorial na década de 1920, mas agora, quarenta anos após o início das transformações incitadas por ele, tratava-se de fazer da produção de um livro uma forma coesa a depender do projeto editorial. Porém, tal ambição mostra-se ainda hoje problemática, herdeira de uma produção fragmentada, a confecção de um livro ainda hoje segmenta a fabricação de suas partes, esse projeto frequentemente limitando-se à parte gráfica.

\subsection{Coleção: projeto, consumo e controle}

Com a disseminação dos avanços tecnológicos e o aumento dos investimentos na indústria gráfica brasileira, mais casas editoriais surgiram e com elas novas oportunidades e consequentemente novos escritores e escritoras, aquecendo um mercado que viria a se informatizar por completo na década de 1990. Além da encadernação em brochura (paperback), que barateou o custo de produção do livro como um todo, o formato coleção funcionou igualmente como um importante alicerce para toda produção editorial. De relação muito próxima, brochura e coleção impulsionaram a produção e a distribuição de livros, agora objeto de preço acessível e identificação imediata.

Diante do esforço de casas editoriais na disseminação do livro, o formato coleção aparece como uma ferramenta que auxiliaria o consumo e dinamizaria sua produção e distribuição. Identificado o perfil dos leitores e leitoras brasileiros, que, como afirma Hallewell (1985), tinha prazer em completar uma coleção e expô-la em sua estante; coleções em fascículos 
como as da Editora Abril tiveram grande sucesso de vendas, mesmo exigindo um valor alto de investimento inicial, as possibilidades de reuso dos fascículos que comporiam cada volume mostrou-se economicamente atraente e de pouco risco.

Coleções de obras completas e de clássicos da literatura estrangeira e nacional, como a coleção Nobel e Biblioteca dos séculos, da Editora Globo, e a coleção Buriti, da Itatiaia, como informa Hallewell (1985) foram de grande importância; se a função de um editor ou editora é selecionar o que vai ou não ser publicado, lançar coleções com o pretexto de trazer o melhor da literatura mundial ou brasileira é mais uma forma de reiterar a relevância de determinadas obras e autores e autoras, conceder uma espécie de controle de qualidade, um atestado às obras, a guiar, desta forma, o que não pode deixar de ser consumido.

As implicações contidas na publicação de uma coleção são de várias ordens; seja por autoria, por temática ou qualquer outro recorte que caracterize determinada coleção, as escolhas sempre revelam posicionamentos e ideologias. Logo, ao propor a análise de uma coleção como a Amores Extremos, pautada em recortes de muitas implicações, tenho, como um dos focos nesta dissertação, a compreensão do que está por trás do projeto da coleção, o que suas escolhas estéticas e textuais revelam sobre a produção literária de mulheres bem como sobre a crença ou não em uma literatura e/ou escrita femininas, ou literatura para mulheres.

O formato coleção não é único, dá-se de diversas maneiras e por variadas razões e recortes. $O$ caráter facilitador e prospectivo contido em sua configuração rapidamente foi visto como um forte veículo de disseminação e consumo dos livros. Projetadas como uma tentativa de cooptar a atenção de diferentes tipos de público, as coleções, mesmo quando produzidas para um grupo específico, não deixavam de ser uma estratégia das casas editoriais de ampliação de seu mercado consumidor, como bem explica Adriana El Far (2006), referindo-se às coleções marcadas pelo recorte de gênero.

Tal recorte mostrou-se bastante proveitoso no formato coleção, pois indicava para quem destinava-se determinado livro e, por consequência, quem não deveria lê-lo. Apesar de as coleções para mulheres serem mais 
recorrentes, até metade do século XX era bastante comum publicações direcionadas ao público masculino, com nomes de mulheres, como Clarita, Carmen e Judith, essas coleções traziam narrativas geralmente pornográficas, razão que os fizeram conhecidos como livros da prateleira de trás (EL FAR, 2006).

Muitas coleções, como Correio das Modas (1839), Biblioteca das famílias (1874) e as coleções Rosa, Azul e Verde produzidas na década de 1950 tinham como público-alvo as mulheres, ou mais especificamente, moças, que tinham a leitura como seu passatempo. José Paulo Paes (1990) chega a falar de uma literatura de entretenimento e de como, no Brasil, nos anos 1930 e 1940, com as obras modernistas distantes do gosto do grande público, não coincidentemente, houve o aparecimento de grandes coleções com o entretenimento como fim. Paes cita o nome de algumas coleções como Terramarear e Máscara Negra que trariam romances de aventura e policiais e a Coleção de Moças, de romances sentimentais, claramente destinadas às mulheres, o que o crítico não salienta é se, assim como as coleções dos conhecidos "livros da prateleira de trás", as outras duas seriam destinadas somente a rapazes. A resposta à questão, pela oposição, pode ser inferida que sim.

$O$ fato é que coleções significavam uma parcela bastante expressiva na venda de livros no país. Coleções de bolso como Sabrina, Júlia e Bianca da editora Nova Cultural, publicadas trinta anos depois e com venda de dois milhões de exemplares (EL FAR, 2006, p. 48) não deixam de ser exemplos desse tipo de coleção pautada, projetada e destinada ao público feminino, modelo ainda hoje adotado no consumo específico de determinadas literaturas, como o caso da Editora Malagueta, que mais que uma coleção, ergue-se como um selo de literatura lésbica para lésbicas, com um projeto de autorrepresentação explícito ${ }^{3}$. Com isso em mente, pergunto-me até que ponto a coleção Amores Extremos, aqui investigada, cujo recorte é a temática amorosa associada à autoria feminina, também não seria um resquício ou mesmo uma tentativa de revitalização desse formato, sendo

\footnotetext{
${ }^{3}$ Ver LEAL, Virgínia Maria Vasconcelos. "Editora Malagueta: Campo literário e identidade lésbica".
} 
pensada não só como uma coleção de mulheres mas também, para mulheres.

\subsection{Autoria feminina: a dúvida que nos quer calar}

Organizada por Luciana Villas-Boas, considerada uma das personalidades mais influentes do mercado editorial brasileiro ${ }^{4}$, e publicada pela editora Record entre os anos de 2001 e 2003, a coleção Amores Extremos, composta por sete obras que partilham do propósito de falar do amor em suas diferentes vertentes, sustenta-se sobre recortes bastantes controversos. A autoria feminina é tema hoje discutido para além das agendas feministas, faz-se presente em diversos âmbitos do discurso, e recorrer a ela como recorte é movimentar questões a respeito não só da presença das mulheres no campo literário (que infelizmente, no Brasil, ainda representam menos de $30 \%$ nas editoras centrais ${ }^{5}$ ), como sobre a existência de uma escrita feminina ou, ainda, de um projeto maior, de uma literatura de mulheres.

A questão mais emergente na produção literária de mulheres, antecipa-se à identificação de uma escrita feminina ou da construção de uma literatura de mulheres, é o inescapável nome de mulher impresso numa capa e todas as implicações nele contidas, independentemente do posicionamento ou engajamento da escritora em questão, que parece suscitar questionamentos e alegações sobre a presença das mulheres na literatura. A dubiedade da existência das mulheres no mundo literário é uma das pautas mais recorrentes no debate acerca da escrita e da literatura feminina, para Marina Colasanti, que em seu texto "Por que perguntam se existimos" (COLASANTI, 1997) debate a persistência de tal indagação. Para ela, a insistência na pergunta justifica-se não pela falta de argumentos, mas

\footnotetext{
${ }^{4}$ Diretora da Editora Record por dezessete anos, Luciana Villas Boas, hoje, agente literária, foi considerada, por um júri composto por 35 profissionais do mundo das letras, elencado pelo jornal Folha de S. Paulo, como a segunda pessoa mais influente no mercado editorial brasileiro. Ver "Os donos do livro". Folha de S. Paulo, 12 de março. 2006. Mais!. p. 4 - 6.

5 Ver pesquisa DALCASTAGNE, Regina. "A personagem do romance brasileiro contemporâneo: 1990 -2004".
} 
antes como fortalecimento de uma estratégia que têm como objetivo colocar em dúvida a já evidente existência feminina na literatura.

De valor sexuado, a obra de uma escritora não escapa às marcas de gênero, carrega em si não só uma narrativa como igualmente aviva uma história pregressa de luta da inserção das mulheres no campo literário. E a partir do momento que compreendemos o gênero nos termos de Teresa de Lauretis (1994), ou seja, como um construto social efetuado por inúmeras tecnologias de gênero, como instituições, como família, religiões, Estado e mesmo a própria literatura, publicar um livro de autoria feminina é inevitavelmente movimentar o conceito de gênero, e propor uma coleção a partir de tal recorte, como o faz a Amores Extremos é mais que atestar a presença das mulheres no campo, é acreditar que essas possuem algo em comum que as singularizam e conectam, logo que as fazem habilitadas para tal tarefa.

Afirmar denominadores comuns entre as mulheres é fatalmente delimitar o que é uma mulher, e se há trinta anos tal definição mostrava-se óbvia, hoje gera um dos maiores desconfortos e desafios ao pensamento feminista, e conceitos como experiência e identidade, que, a princípio, mostraram-se matérias-primas de maior força no combate à lógica patriarcal, foram denunciados como frágeis e problemáticos. Ao buscarem enxergar-se fora dos padrões androcêntricos, a partir de olhares e termos próprios, as mulheres fizeram da experiência uma importante fonte de conhecimento e reconhecimento, todavia buscar legitimidade na autoridade que a experiência Ihes oferecia era enxergá-la de forma isolada, blindada, como disserta Susana Funck (2011), que ao propor-se a difícil tarefa de articular o que é uma mulher, evidencia, a partir de leituras dos estudos de Joan Scott, os mal-entendidos gerados pelo uso da experiência como sustentáculo do pensamento feminista:

A busca de legitimidade na autoridade da experiência como ponto de
partida para a crítica ou para a explicação, segundo Scott, reduz e
enfraquece qualquer argumentação, por se colocar de fora da
construção discursiva que a possibilitou. Ou seja, toma a visão como
límpida e a linguagem como transparente, ignorando o modo pelo qual o
sujeito que experiencia foi socialmente (e ideologicamente)
constituído.[...] experiência é um processo que transforma em subjetivas
relações que são, em verdade, sociais e históricas - e, portanto,
contingentes. Assim ao ser afirmada, minha experiência como mulher 
necessariamente exclui outras experiências de "mulheridade", universalizando o particular e generalizando o local. (FUNCK, 2011, p. 66)

Mesmo frágil, o conceito de experiência não pode ser ignorado; descartada pela lógica do pensamento teórico androcêntrico que procurou livrar-se de qualquer aspecto subjetivo, defendendo-se como absoluto e científico - como se os saberes científicos não fossem, em larga medida, mediados pela cultura - a experiência aparece como um vínculo direto com a realidade, aspecto esse tão caro à crítica feminista, que ao misturar discurso e experiência consegue transitar entre teoria e práticas políticas. Sendo social, histórica e, por essa razão, contingente, como reforça Funck (2011), a experiência contradiz o saber puro, possibilita o processo de subjetivação e o sentido de pertencimento que estrutura a ação política do movimento feminista, não cabendo, assim, sua exclusão, mas antes, sua historicização, como sugere Scott, uma vez que social e pessoal constroemse mutuamente.

Quando enxergamos a experiência como resultado e reflexo de uma série de fatores sociais e materiais que todas nós temos de lidar e compreendemos o gênero como uma variável que altera, de forma decisiva, como lidamos e nos relacionamos com esses fatores, entendemos o porquê de a experiência ser conceito-chave, apesar de ambíguo, nas teorias feministas. Porém, apesar de decisivo, o gênero não é o único atributo que temos de lidar; raça, classe social, sexualidade, entre outros, são categorias que igualmente nos delimita e das quais o gênero não pode isolar-se, uma vez que é significadamente modificado quando posto ao lado dessas, motivo que faz o assumir mulheres como um único grupo um equívoco, uma vez que tomá-las no singular é eleger um ponto de vista privilegiado, é tomar erroneamente uma única experiência (branca, heterossexual, de classe média) como representativa das mulheres, tal como apontou Sojourner Truth $^{6}$ em seu famoso discurso Ain't I a Woman? proferido na Convenção

\footnotetext{
${ }^{6}$ Em seu famoso discurso "Ain't I a Womam?", proferido na Convenção Nacional de Mulheres ocorrida na cidade de Akron, em Ohio no ano de 1851, Sojourner Truth, exescrava norte-americana, denuncia as diferenças entre as mulheres ao gritar suas diferenças. "Ninguém jamais me ajudou a subir em carruagens, ou a saltar sobre poças de lama, e nunca me ofereceram melhor lugar algum! E não sou uma mulher? Olhem para
} 
Nacional de Mulheres em Ohio, em 1851. Todavia, sem algo que nos una como categoria, reivindicações e denúncias tornam-se esvaziadas e individuais, como bem afirma Iris Young (2003, p. 118), o que consequentemente dissolve a necessidade e a existência do movimento feminista.

Se não se conceitualizar de algum modo as mulheres como grupo, não será possível conceitualizar a opressão como um processo sistemático, estrutural e institucional. Se obedecermos ao preceito de estender as pessoas apenas como indivíduos, então as desvantagens e as exclusões a que chamamos opressões serão reduzidas ao indivíduo[...]

Diante desse impasse, a filósofa política sugere como alternativa à armadilha de pensar mulheres como grupo, enxergá-las como uma série. A partir dos estudos de Jean-Paul Sartre, a autora propõe uma reconceitualização de coletividade social, a começar da diferenciação entre grupo e série. Enquanto os grupos formariam-se a partir de um projeto explícito e conscientemente compartilhado por todos os seus membros, a série seria um coletivo reunido de forma passiva e inconsciente, "unidos pelos objectos (sic) para os quais as suas acções (sic) estão orientadas, e/ou pelos resultados objectivados (sic) dos efeitos materiais das acções (sic) dos outros" (YOUNG, 2003, p. 125). Pensar as mulheres como série foi o escape que Young encontrou na tentativa de fazer das mulheres um coletivo sem partir do pressuposto que todas nós mulheres possuamos as mesmas experiências, estejamos na mesma situação; como unidade fluída, a série equaciona as mulheres não por essas possuírem atributos específicos, mas por inevitavelmente enfrentarem, conscientemente ou não, as marcas do gênero.

Dos fatos sociais e materiais que constroem o gênero, o corpo, como objeto social, inscrito e produzido pela cultura, cinge possibilidades e reduz reconhecimentos, estabelecendo, assim, as marcas de gênero.

mim? Olhem para meus braços! Eu arei e plantei, e juntei a colheita nos celeiros, e homem algum poderia estar à minha frente. E não sou uma mulher? Eu poderia trabalhar tanto $e$ comer tanto quanto qualquer homem - desde que eu tivesse oportunidade para isso - e suportar o açoite também! E não sou uma mulher? Eu pari treze filhos e vi a maioria deles ser vendida para a escravidão, e quando eu clamei com a minha dor de mãe, ninguém a não ser Jesus me ouviu! $E$ não sou uma mulher?". Disponível em: http://arquivo.geledes.org.br/atlantico-negro/afroamericanos/sojourner-truth/22661-e-naosou-uma-mulher-sojourner-truth?fb_locale=pt_BR. Acesso em: 14 de dezembro 2015. 
Conjuntamente a outros objetos sociais (nem sempre físicos), o corpo funciona para além de uma identificação, serve como um dos principais aportes para a serialização de mulheres, processo este reiterado por inúmeras práticas sociais, entre elas, representações verbais e visuais, que podem até condicionar ações, comportamentos e, claro, suas interpretações, mas não alcançam o poder de nos definir e limitar, dado que vivemos e experienciamos o gênero e todos os fatos e objetos sociais que o acompanham e circunscrevem de forma subjetiva. E insistir numa identidade comum e compartilhada entre as mulheres, como fazem alguns feminismos na busca por uma estratégia de representatividade, é inevitavelmente delimitar por quem se fala, logo excluir aqueles a quem a representação não alcança.

\subsubsection{Corpo, identidade e ordem discursiva}

Assim como o temo mulher, de início óbvio, hoje cheio de ressalvas e suspeições, corpo tornou-se, na crítica feminista, palavra cujo uso não se deve dar de maneira fortuita. Utilizado como justificativa genuína de uma dissimulada hierarquização social, o corpo foi pensado e materializado para produzir, evidenciar e justificar diferenças entre homens e mulheres, ou mais especificamente, a diferença da mulher em relação ao homem. E a diferença sexual, frequentemente encarada como uma diferença mais biológica, material, colaborou para fazer do sexo uma espécie de categoria anterior ao discurso, quando efetivamente, nem mesmo o corpo escapa à ordem discursiva.

Duvidar da indubitabilidade do corpo e de todas as alegações que provinham dele ou nele se justificavam acarretou transformações que ultrapassaram críticas e teorias feministas. Usado como um dos grandes suportes para se pensar o mundo social, o corpo, desprovido de seu caráter de substância matriz, desarranjou um dos principais jogos de referência da organização social, a diferença entre os sexos, e desarticulou um dos eixos de sistematização do estar no mundo, a identidade. Mas, uma vez que corpo e identidade ancoram e viabilizam o nosso ser e estar no mundo, desmistificá-los ainda hoje é um desafio e um desconforto. 
Os feminismos, como um agente de mudanças, conjuntamente a outros avanços na teoria social e nas ciências humanas, ao pulverizar centros de referência, como o corpo e o sexo, fragmentou sujeitos, descentrando suas identidades, que passaram a não mais possuir um único centro sólido para se reerguerem. Entretanto, refutar tais cernes é uma via de mão dupla, já que desconstruí-los é, simultaneamente, por em xeque seu maior sustentáculo: a figura da mulher, mas não fazê-lo é permanecer restrito a bases e suposições patriarcais, que reteve as mulheres no interior de seus corpos.

A lógica patriarcal, herdeira de um pensamento cartesiano, que partiu o ser em mente e corpo, encontrou na anatomia feminina justificativas convenientes para validar a condição de subordinação das mulheres na sociedade. Considerando que fazer uso de qualquer distinção estabelecida pelo pensamento dicotômico é inevitavelmente reavivar todos os outros pares, pautar-se na divisão mente/corpo é consequentemente concatenar tal divisão para o binômio homem/mulher. Mais do que associar a mulher ao corpo, o pensamento dicotômico, que tem a hierarquia como pressuposto básico, categorizou ambos como o par inferior.

Restritas ao corpo, mulheres tiveram identidades, capacidades cognitivas, sexualidade e papeis sociais erguidos, limitados e justificados a partir de sua anatomia, o que fez do corpo tópico por vezes hostil para algumas teóricas feministas. Todavia, devido à sua constante e inevitável presença, o debate sobre o corpo ganhou novos contornos, ao ponto de hoje ser foco de ações políticas e produções teóricas feministas. No entanto, a despeito de sua concretude, ou ironicamente por causa dela, o corpo permaneceu fora do campo de visão de muitas teóricas feministas, que o adotaram de forma acrítica, reforçando seu status de dado bruto e biológico, reiterando, assim, a lógica dicotômica que subalterniza mulheres.

$\mathrm{Na}$ busca de uma origem da dominação masculina, o corpo, ou mais especificamente o sistema reprodutivo, como um denominador comum entre as mulheres, apareceu como uma possível resposta à condição de inferioridade que parecia assolar às mulheres de forma generalizada e universal. Suspeitar desse status de inferioridade foi um primeiro passo das feministas na desarticulação desse tipo de pensamento, e o conceito de 
patriarcado foi peça importante nesse processo, pois possibilitou enxergar dentre uma multiplicidade de relações de poder a articulação na construção da subordinação das mulheres.

Como uma ideia global e absoluta de poder, o patriarcado, ainda que explicasse a manutenção do sexismo, como aponta Adriana Piscitelli (2004), permanecia como um conceito genérico e essencializante, praticamente sinônimo de dominação masculina. Tendo na biologia seu principal amparo, não só presumia uma forma singular de opressão, como supunha uma identidade comum entre as mulheres, dado que essa era entendida como um reflexo direto do corpo, que como um dado biológico permaneceria indiferente a contextos e aspectos culturais. Se duvidar da condição de opressão foi um grande passo na desmistificação da inferioridade feminina na sociedade, deixar o corpo incólume só reforçou seu caráter determinista.

Diante desse aparente imperativo do corpo, muitas feministas pioneiras, como Mary Wollstonecraft e Simone de Beauvoir, creditaram à anatomia feminina e todos os seus processos biológicos a causa-mor da limitação do acesso a diretos, restando a nós, mulheres, na luta pela igualdade de direitos, ignorar o corpo e ansiar pela mente. Pautar-se em tal pensamento é acreditar, como bem aponta a interpretação de Elizabeth Grozs (2000), que somente o corpo, restrito às mulheres, seria sexuado, enquanto a mente, por consequência, associada ao masculino, seria sexualmente neutra, logo o nosso único meio de ascensão social.

Antes de arriscarem duvidar do corpo, algumas feministas reexaminaram o papel da mente na lógica dicotômica que a separava do corpo, não os enxergando como pólos excludentes, mas antes como um jogo de atribuição de significados. Feministas marxistas e psicanalistas ${ }^{7}$, ainda munindo o corpo de autenticidade, passaram a vislumbrar na mente um espaço de intervenção no discurso sobre as mulheres. Vista como um objeto histórico-social, a mente atuaria sobre o corpo, interpretando suas diferenças, mas ainda que este modelo admita a significação do corpo por uma ideologia e coloque em dúvida a objetividade e isenção suplantada no conceito de mente, o corpo permanece na sua condição de núcleo a partir

\footnotetext{
${ }^{7}$ Ver SHOWALTER, Elaine. "A crítica feminista no território selvagem".
} 
de onde os significados seriam construídos, o que somente causou uma nova bifurcação do corpo, agora pensado em termos de natureza e cultura.

Da divisão entre corpo biológico e corpo ideológico ergueu-se uma das estratégias de maior impacto dentro do movimento e da teoria feminista, o sistema sexo/gênero. Se inicialmente o conceito de gênero eclode como uma alternativa ao impalpável e generalista patriarcado e do desejo de fazer frente ao pensamento marxista, que focado em aspectos como classe social, o tratou de forma essencialista, e, é no sistema sexo/gênero proposto por Gayle Rubin, em seu ensaio "O tráfico das mulheres: notas sobre a economia política do sexo", de 1975, que ele ganha força e espaço dentro dos estudos feministas.

Rubin, ao nomear e distinguir fator biológico e seu significado socialmente construído, conseguiu enxergar, de forma ampla e sistemática, os arranjos culturais que se formavam em torno do sexo com o objetivo erguer e modelar construções sociais possíveis de mulheres. Todavia, ancorada numa matéria-prima biológica, a antropóloga, que buscou desnaturalizar a condição de subordinação e opressão que assolava as mulheres, limitou o alcance de seu olhar crítico à superfície do corpo ao encarar o sexo como substância fundadora do gênero, mantendo-se, assim, refém de seus próprios termos e conceitos, visto que repisava os mesmos pressupostos (patriarcais) que visava combater. Uma vez que ainda estava partindo, segundo críticas posteriores, de um mesmo modelo baseado na dualidade.

A noção de gênero, ao nos abrir os olhos para os contornos discursivos em redor do corpo, deu início a um processo de desconstrução de grande dimensão e alcance, que viria a por em xeque uma série de pressupostos e certezas que sustentavam inclusive o próprio pensamento feminista. A partir dos estudos de Michel Foucault, mais especificamente os feitos sobre sexualidade, feministas como Donna Haraway, Judith Butler e Monique Wittig buscaram repensar o conceito de gênero e por conseguinte rever e reelaborar pressupostos teóricos e políticos feministas. Com a proposta de enxergar o sexo como uma prática regulatória que não só produziria os corpos, como os governaria, o filósofo despe o corpo de sua 
aparente condição de autenticidade o evidenciando como mais um mecanismo de coercitividade na materialização das diferenças.

Das reformulações propostas para o gênero, a defendida por Judith Butler talvez seja uma das mais controversas nos estudos feministas. Conhecida por dispensar rótulos e desconstruir conceitos, a filósofa fragilizou categorias importantes para o feminismo ao desestabilizar o sistema sexo/gênero e trazer o corpo como objeto discursivo. Ao propor o sexo como algo construído por uma operação discursiva, e não o contrário como a divisão sexo/gênero insinua; considerar o gênero como o aparato por meio do qual se dá essa construção e compreender a materialidade do corpo como o efeito dessas práticas, Butler delineia a arquitetura por trás do jogo responsável por promover a eficácia e a estabilidade da estrutura binária do sexo.

No jogo desmontado por Butler, sexo, gênero e corpo se retroalimentam na construção e manutenção da diferença sexual e não mais se hierarquizam. O sexo, como um poder produtivo, funciona como uma norma, que ao ser imposta reiteradamente, regula os corpos que ele mesmo produz. Como consequência direta, ou nos termos da filósofa, como efeito, dessa repetida e onipresente imposição, o sexo é, assim, materializado. A exigência dessa constante manutenção aparece como evidência de que esse processo nunca é completo, cabendo, assim, rematerializações.

Motivadas pelo ideal regulatório imposto pelo sexo, as práticas reiterativas são, no pensamento de Butler, performáticas. Ao condicionar atos e gestos e estilizar corpos, tais práticas produzem uma ilusão de naturalidade, quando, efetivamente, são práticas dotadas de intencionalidade e têm sua materialidade consumada no corpo, esta sendo sequela das ininterruptas interpelações que somos mais que obrigados e obrigadas a responder, somos condicionados e condicionadas a optar por determinadas respostas. Para quem não acata as disposições e ações determinadas e desestabiliza a lógica imposta e patrulhada, resta a exclusão, ou ainda, para usar o termo cunhado pela autora, a abjeção.

Práticas e discursos, como a literatura, ao promoverem certas identificações sexuadas, simultaneamente, tolhem ou mesmo enjeitam outras identificações. Para Butler, mais que excluído o sujeito que 
desestabiliza a coerência construída entre corpo, sexo e gênero é privado do usufruto de uma identidade. Nossos corpos só se tornam possíveis quando contornados como femininos ou masculinos, possuir uma identidade é antes de tudo entrar em concordância com esse corpo macho ou fêmea. Assumir um sexo é rito inescapável do processo de construção de uma identidade, que só se torna possível, cognoscível dentro da ordem compulsória existente entre sexo, gênero, desejo e prática sexuais. Matriz de inteligibilidade é o nome dado por Butler na tentativa de explicitar esse processo de produção dos ditos "gêneros inteligíveis" (BUTLER, 2003, p. 38). A filósofa ainda adicionou ao sistema sexo/gênero a sexualidade, dado que a heteronormatividade seria mais de um elemento de peso na construção e factibilidade dos sujeitos. O seu conceito de matriz de inteligibilidade será retomado adiante para pensar criticamente a "inteligibiildade" da coleção, objeto deste trabalho.

Abjetos são, na teoria de Butler, os corpos que não se encaixam na lógica imposta pela matriz de inteligibilidade. São corpos não legitimados, logo que não usufruem do status de sujeito. Localizados no que autora define como "zona de inabitabilidade", os seres abjetos seriam parte importante no processo de construção das identidades. Ao demarcarem e sublinharem a fronteira, esse seres atuariam como "limite definidor do domínio do sujeito" (BUTLER, 2013, p. 155), que se constrói também pelo intermédio do repúdio. Dessa forma, a categoria identidade, asseverada por conceitos estabilizadores, logo excludentes, funciona como mais um instrumento normativo, na perspectiva desconstrutivista de Butler, que aponta o quão perigoso é estabelecer uma política feminista com base numa identidade comum e definida. Para a autora, delimitar por quem se fala é, inevitavelmente, criar um "domínio de exclusão" (BUTLER, 2003, p. 22) é deixar de fora aqueles a quem a representação não alcança. $E$ um modelo de representação que busca na categoria das mulheres seu foco repete as operações que ele, em teoria, buscaria combater.

Tendo consciência de que não há posicionamento fora das relações de poder, Butler propõe que o foco do pensamento feminista seja a crítica constante das categorias de identidade, que mais imobilizam que emancipam, de modo a construir uma política representacional que repense 
o feminismo com base em outros termos, que devem manter-se abertos e permanentemente sob vigília. Duvidar das categorias base do pensamento feminista foi um dos grandes desafios incitados por Butler, que ao repensálas fragilizou certezas articuladas dentro dos próprios estudos feministas, que nesse dilema de ter sido construídos sob dois pólos, o da prática e o da teoria, nem sempre convergentes, vêm enfrentando desafios que exigem de nós cada vez mais suspeição.

Manter-se vigilante a qualquer tipo de amarras que possam limitar 0 pensamento fez de Judith Butler um dos grandes nomes do feminismo contemporâneo, ainda assim, a pensadora é constantemente criticada por construir teorias que não alcançariam condições reais de opressão, entretanto pensar e fazer são ações que fizeram e fazem o feminismo se desenvolver, ao ponto de hoje se tornarem feminismos. O movimento feminista pode ter origem nas ruas, mas precisa se fazer presente em todos os espaços e instâncias.

\subsubsection{Mulher e literatura: aproximações e implicações}

Onde quer que se leve ou aplique o termo "mulher", normas e comportamentos socialmente definidos irão se fazer presentes, distinguindo e sublinhando a "valência sexuada" (RICHARD, 2002, p. 129) que esse termo permanentemente produz. Restando-nos não o ingênuo e nocivo desejo de neutralização, ou ainda a investigação de uma origem, que muitas vezes só serve para naturalizar hierarquias e mascarar privilégios, mas antes politizar e rearticular velhas questões que ainda hoje insistem em nos encaixar num "feminino" fixo e limitador.

Aproximar o termo mulher e literatura, independentemente da preposição que os una, é tarefa com muitas implicações, a mais notória delas talvez seja a marca de diferença que o termo mulher imprime sobre literatura. Adjetivar uma literatura (ou mesmo uma escrita) é partir do pressuposto de que existe uma, que dispensa apresentações, enquanto outras (feminina, negra, latina) só existem se postas e marcadas no lugar que lhes cabe. $\mathrm{E}$ na tentativa de delimitar o território ocupado pelas 
mulheres, noções como escrita feminina e literatura de mulheres mostram-se ferramentas muito eficazes.

Ao descrever e disseminar papeis sociais em suas variadas dimensões, a escrita, como um veículo de dominação, sempre esteve ligada ao poder, o que justifica, em grande parte, o porquê de ter sido negada às mulheres por tanto tempo. Todavia, enxergada a importância do ler e escrever, as primeiras feministas fizeram do acesso à alfabetização sua primeira bandeira e da escrita uma de suas principais armas no combate às desigualdades. Conquistado o acesso à alfabetização, as mulheres, sumariamente burguesas, passaram não somente a ler como também escrever e publicar, porém a trajetória de ascensão à palavra escrita foi marcada por muitos percalços, de barreiras materiais a amarras nem tão visíveis, mas igualmente prejudiciais.

É no que há de mais concreto e primordial ao ato de escrever que, Virgínia Woolf, em seu famoso ensaio Um teto todo seu (2014), constata uma das principais circunstâncias que distanciaram as mulheres da produção de ficção, a pobreza material. A concretude das diferenças é um dos maiores argumentos que Woolf utiliza para postular a necessidade de um teto todo seu por parte das mulheres, e que precisa ser encarada, uma vez que muitos postulam que homens e mulheres são iguais; e pensar nos efeitos da "pobreza material de nosso sexo" e de como essa falta se situa no contexto de produção de mulheres, que tiveram de aprender a lidar inclusive como a falta de uma tradição, é imprescindível para compreender a ausência e invisibilidade da produção de mulheres. A própria Woolf elenca uma série de autoras que, de diferentes formas, compõem essa tradição de vozes de mulheres na composição de uma tradição literária, tradição essa que não é só responsável por mostrar a história, a existência das mulheres, mas, principalmente, mostrar sua resistência, visto que as mulheres lutaram por seu lugar nesse contexto.

Numa trajetória, que mistura teoria e experiência, duas matérias ainda hoje utilizadas pela crítica feminista e que a permitem transitar entre teoria e práticas sociais, Woolf busca uma voz própria, uma forma de construção de conhecimento distinta da estabelecida pela tradição hegemônica (masculina) da escrita e argumenta que uma forma de voltar-se contra essa realidade é 
por meio da independência financeira, que vale mais, muitas vezes, que prerrogativas políticas, "dos dois -0 voto e o dinheiro -0 dinheiro, reconheço, pareceria infinitamente mais importante" (WOOLF, 2014, p.57). Ao colocar as condições materiais como influenciadoras das condições de produção literária, a autora questiona a ideia de que mulheres não produziam porque não sabiam e coloca que, se as mulheres não produziam, até o momento em que ela escreve, tanto quanto os homens, é porque não possuíam condições materiais para isso.

Dos obstáculos a serem ultrapassados pelas mulheres, o material não seria o único, mesmo transpostas barreiras, como a pobreza, ainda resta obstáculos de valoração da crítica, que reiteram mecanismos de poder estabelecidos hegemonicamente e que estabelecem que livros escritos por mulheres, que tratam de questões da "sala de pintura" (WOOLF, 2014, p.107), são insignificantes. Ao rotular ou mesmo ignorar a produção de mulheres na produção ficcional há não só um empobrecimento das representações nas obras literárias como da própria literatura, uma vez que como afirma Woolf, "a literatura seria incrivelmente depauperada, como de fato é depauperada além da conta pelas portas que foram fechadas na cara das mulheres (WOOLF, 2014, p.121) e, estendendo a afirmação de Woolf, quanto mais diversos são os escritores e escritoras, mais diversas serão as representações que criam e consequentemente a literatura de um modo geral.

A produção literária feita por mulheres sempre foi marginalizada, ou mesmo omitida, pela tradição literária e seu cânone, porém em duas situações a produção feminina é vista com outros olhos, como salienta Nelly Richard (2002, p. 128):

quando recuperam sob 0 subterfúgio paternalista do falso reconhecimento e, também, quando o mercado promove essa literatura como simulacro de uma "diferença" exaltada pela feira de consumo para multiplicar — de modo banal — a "diferenciação" de seus produtos.

Sendo esperada dentro da lógica da mudança, já prevista na própria organização do campo literário, como argumenta Pierre Bourdieu (1996), ou vendida e lida sob o selo de uma produção feminina, a literatura feita por mulheres não incomodaria o sistema literário dominante, todavia faz-se 
necessário lembrar que antes de (algumas) serem aceitas ou encaixadas no campo literário, a inserção das mulheres se deu por meio de lutas e conquistas travadas por gerações de mulheres, que fizeram do feminismo um agente de transformação, uma força capaz de alterar o campo, que se viu obrigado a se reestruturar.

Se um nome de mulher na capa já incita uma série de implicações a respeito do texto que carrega, identificações como "escrita feminina" e "literatura de mulheres" delimitam, de forma ainda mais efetiva e definitiva, posições e valores de obras escritas e/ou pensadas à sombra de tais insígnias. Independente de creditarmos às diferenças das produções literárias feitas por mulheres a um modo de escrever específico, tipificando-o como feminino; ou ainda a temáticas prescritas como pertencentes às mulheres, as marcas de sexo e de gênero serão sempre apreçadas e avaliadas, restando às autoras, aos leitores e leitoras, e o próprio campo literário lidar com essas marcas e todos os conceitos e categorias movimentados com o seu uso. É nesse "lidar" que se centra minha pesquisa, a coleção Amores Extremos pensada e vendida como uma demonstração da literatura feita por mulheres no Brasil, ao sublinhar a condição de mulher das escritoras, as persuade a não só escrever como mulheres como as compele a manejar sua marca de gênero dentro de sua produção literária, que será, de muitas formas, medida e consumida a partir de tal relação.

Falar de literatura feita por mulheres é frequentemente discutir a existência ou não de uma escrita feminina, mas, ao pautarmos sua existência, somos obrigadas/obrigados a nos perguntar que características da escrita seriam tipificadas como pertencentes a uma escrita sublinhada como feminina. Ancoradas nos corpos, as diferenças entre homens e mulheres são, até certo ponto, perceptíveis, apesar de já serem confrontadas por figuras como drag queens e cross-dressers, estudadas por Butler, mas quando transpomos essa diferença para o texto, o que exatamente classificaria uma escrita como feminina, que características seriam tipificadas como pertencentes a essa escrita? Apesar de já existirem 
linhas de pesquisas preocupadas com essa indagação ${ }^{8}$, debruço-me aqui sobre as prerrogativas e as implicações que constroem e sustentam esse feminino, que reiterado por inúmeras práticas e representações, hoje, funciona quase que autonomamente.

A teórica feminista Nelly Richard (2002) aponta que tanto a escrita feminina pautada num nível expressivo, que busca identificar um estilo feminino, quanto num nível temático, a procura de correspondências e verossimilhanças entre o que acreditava-se ser uma mulher e sua representação, apresentam problemas, pois têm como prerrogativa não só uma identidade-essência como partem do pressuposto que mulheres só escreveriam a partir de suas vivências, sendo o real sua única fonte de criação. E estudar uma coleção pensada a partir de recortes como autoria feminina e temática amorosa, me faz pensar até que ponto propor tal temática a escritoras mulheres não é alimentar essa concepção, o amor sendo, assim, uma experiência não restrita, mas comum e inevitável na vida de todas nós mulheres.

Identificar discursos e práticas que alimentam esse feminino, cotidianamente reiterado por inúmeras práticas e representações é meu maior objetivo na análise não só de cada narrativa que compõe a coleção, mas sobretudo no estudo da coleção como um projeto. Pensada e projetada a partir de algum tipo de demanda, que pode vir de diferentes ordens, como mercadológicas, pelo crescente interesse em produções de mulheres e econômicas pela grande maioria do público leitor brasileiro ser composto por mulheres, a coleção Amores Extremos deve ser lida para além de suas sete narrativas.

Olhar para o corpo e o amor representados na coleção é um dos percursos por mim escolhido na tentativa de compreender como autoras lidam com as marcas do gênero. O corpo como peça-chave na organização e execução da nossa viabilidade como sujeitos sociais, sendo sua materialidade um efeito do jogo construído entre sexo, gênero, prática e desejo sexuais, nos termos da matriz de inteligibilidade de Butler, torna-se

\footnotetext{
${ }^{8}$ Linhas de pesquisa como crítica linguistica defendida por autoras como Robin Lakoff e a psicanalítica de pensadoras como Julia Kristeva e Hélène Cixous centram-se na discussão da existência de uma língua e escrita femininas sob um viés em que não irei debruçar-me.
} 
assim grande indício do que cada autora pensa e representa sobre as mulheres. Da mesma forma como o corpo é cobrado a transparecer nossa identidade, a capa de um livro é solicitada a expor alguma informação que diga algo a seu respeito. Numa coleção, a capa torna-se ainda mais significativa, visto que, muitas vezes, é projetada como um elemento de conexão entre as obras, o que fornece uma identidade visual à coleção e evidencia, por meio das escolhas gráficas, intenções e pressuposições acerca da coleção e de seus recortes.

Com o olhar duplamente voltado para as capas e para as possibilidades de gênero representadas nas personagens das sete escritoras em suas obras, investigo se essas caminham ou não para a formação de uma consciência feminista, no sentido de desafiar o jogo pelo qual se é pensado o feminino. Ou se apenas reproduzem uma matriz dominante de inteligibilidade do gênero, nos termos de Butler. 


\section{Capítulo II}

\subsection{As extremidades do amor}

Se o ato de escrever, quando associado às mulheres, ainda causa estranheza, como bem evidencia a insistência em seu questionamento, escrever sobre amor parece causar menos estremecimento no mundo das letras. Frequentemente associado às mulheres, o amor, assim como o corpo, tornou-se um limite construtor dos papeis de gênero, sobretudo para as mulheres, a quem o amor passou a ser responsabilidade. Escrever sobre amor seria, assim, escrever nos limites consentidos pelos gêneros, o que não significa necessariamente reproduzir a ideologia de desigualdade entre os gêneros, pois é justamente na desarticulação das demarcações que nos limitam que se dão grandes transformações. Todavia escrever sobre o amor a partir de um lugar de fala sublinhado pelo sexo, como ocorre na coleção Amores Extremos, é inevitavelmente movimentar categorias e concepções muito caras aos estudos feministas e de gênero.

De contornos imprecisos, salvo pela literatura, que com todas as suas figuras de linguagem e jogo retórico parecia ser a única a possuir termos e palavras adequados, o amor escapou de lentes críticas por muito tempo. Coberto por uma espécie de aura mística, ele foi construído como algo desconexo da realidade, isento de interesses e julgamentos; e como sentimento natural e universal que escapava às mãos da razão, começa a ser estudado como artefato discursivo a partir dos anos 1970, quando variáveis como gênero, classe social e etnia passaram a ser avaliadas e acentuadas no processo de construção do conhecimento sobre o amor (NEVES, 2007).

Mas apontar o amor, assim como um substantivo solto em uma frase, é ainda adotá-lo de maneira acrítica. Nas suas mais diversas concepções, o amor aparece acompanhado de uma série de preceitos e peculiaridades que não apenas o delineiam como conduzem comportamentos aceitáveis. São nesses discursos e prescrições construídos a partir e em nome do amor que concentro minha investigação, mais especificamente acerca do amor romântico que, ao redefinir papéis de gênero, impactou de maneira decisiva 
a vida das mulheres. E considerando que a coleção, ainda que proponha trazer diferentes facetas do amor, permanece restrita a tal concepção.

Com a consolidação do capitalismo, a ascensão da burguesia e a instauração de um novo modelo de vida, agora urbano, novas mentalidades e alternativas de convívio social surgem; e a vida, assim como o espaço da cidade, é reorganizada nas suas mais variadas dimensões. $\mathrm{Na}$ implementação dessa nova organização, o amor, agora romântico, associado ao casamento, à maternidade e coagido por figuras como a da "solteirona", foi transformado numa engrenagem indispensável na instauração e, principalmente na manutenção, do modelo de vida burguês. $E$ se já há algum tempo as mulheres eram educadas para o amor, agora eram ensinadas a enxergar no casamento a única possibilidade de realização pessoal e concretização do estado pleno de felicidade prometido pelo amor.

A literatura teve papel preponderante nessa educação das mulheres, em sua constituição e revigoramento. Romances recheados de narrativas românticas, como os de M. Delly, largamente lidos no Brasil na década de 1950, promoveram parâmetros de conduta e afeições. Todavia ser amplamente lido não significa ser aceito em mesma proporção, mulheres como a escritora Ercília Nogueira Cobra, já na década de 1920, criticava romances e folhetins, os acusando de inimigos da emancipação feminina ${ }^{9}$.

Enquanto na família patriarcal o casamento era regido por interesses sócio-econômicos e de responsabilidade dos pais, já no fim do século XVIII, com o avanço do individualismo, característico do pensamento burguês, os parâmetros da conjugalidade centravam-se cada vez mais no indivíduo e em suas escolhas, que diziam responder somente às ditas exigências do coração. Atrair e manter as mulheres, que já demonstravam suas insatisfações e igualmente reivindicavam seu direto de escolha, para o casamento, também deve ser considerado aspecto preponderante para tal mudança, como aponta Cláudia Maia (2011, p. 126).

Ainda que construído como um sentimento transgressor, livre de amarras e obrigações sociais, fiel apenas a si mesmo, o amor romântico foi domado e ressignificado a serviço da máquina burguesa, que organizada em

\footnotetext{
${ }^{9}$ Ver MAIA, Claúdia. A invenção da solteirona.
} 
torno da figura da família, o manteve sob controle por meio de sua associação ao casamento e à maternidade, como bem aponta Anthony Giddens (1993), e fez de tal vinculação caminho único de realização pessoal e concretização do ideal de felicidade, fundamentados e justificados pelo poder de escolha.

O casamento não mais baseado em valores que, por sua vez, impunham "coerções", como afirma Denis Rougemont (1988), que as dividiu em três tipos (sagradas, sociais e religiosas) ${ }^{10}$, passou a se uma decisão individual. Porém se aparentemente nada além do sentimento de amor levasse alguém a se casar, os esforços, agora concentrados no poder de escolha, ganharam novas roupagens e coerções. Embora os casamentos já não se dessem por arranjos de interesse sócio-econômicos, a promoção de determinados padrões, erguidos a partir de critérios como etnia e classe social, assegurou os limites possíveis e cabíveis dentro de um perigoso universo de escolhas. Os rompantes das paixões foram, assim, filtrados e postos a serviço de "uma afetividade conjugal cheia de normas, cheia de regras" (DEL PRIORE, 2006. p. 253).

O poder escolher, ainda que um poder, encontrava-se subordinado a uma série de padrões que visavam a estabilidade da figura da família burguesa, dentre eles, a preferência masculina. Coube às mulheres, então, não escolher, mas ser escolhida. Tornar-se uma candidata atraente, despertar o interesse de um homem por meio de seus atributos era, assim, tarefa das mulheres. Dessa forma, conquistar um marido passou a ser compreendido como um indicativo de sucesso, ou fracasso, das mulheres, que cientes das regras do jogo das escolhas conjugais, viram-se compelidas a se enquadrar num modelo de esposa cobiçado pelos homens, que igualmente foram instruídos a escolher determinado padrão de mulher para uma vida conjugal.

\footnotetext{
${ }^{10}$ Denis Rougemont divide em três tipos as coerções que seriam impostas a favor da instituição matrimonial: 1. Coerções sagradas, que diriam respeito aos ritos que foram conservados por muito tempo, como o dote ou mesmo o rapto de uma noiva, por exemplo. 2. Coerções sociais, que envolveriam as questões de posição social, como negócios entre famílias e 3. Coerções religiosas responsáveis pela instauração do "felizes para sempre" e das abnegações intrínsecas a ele. ROUGEMONT, Denis. O amor e o Ocidente.
} 
É sabido que o amor romântico afetou a vida de homens e mulheres de diferentes formas, apesar de preponderante na situação das mulheres, os homens não permaneceram incólumes ao ethos do amor romântico. Giddens (1993) afirma que, em seus estudos acerca da intimidade e suas transformações, para a maioria dos homens, o amor romântico entrava em desacordo com as regras de sedução. O sociólogo ainda afirma que, responsáveis por assuntos externos à casa, na divisão de tarefas, os homens permaneceram afastados do domínio da intimidade, e aqueles que se atreveram ao romantismo, pondo-se a mercê das vontades do amor, ignorando a divisão fundadora da sexualidade masculina, que categorizava mulheres como puras ou maculadas, foram isolados, taxados de românticos sonhadores.

O amor romântico instituído aos moldes burgueses e fundamentado na intimidade matrimonial funcionou como uma importante tecnologia de poder, ou ainda tecnologia de gênero, nos termos de Lauretis (1994), na hierarquização entre os sexos, e como tal não apenas promoveu determinados comportamentos, como a heterossexualidade compulsória, como consequentemente repugnou todos os considerados desviantes da norma. Se a "livre escolha" fez as relações matrimoniais aparentemente mais igualitárias e ajudou a atrair as mulheres para a vida conjugal; não ser escolhida contribui de forma igualmente relevante. A repulsa criada em torno da figura da mulher celibatária foi gesto de grande peso na construção e principalmente no fortalecimento do modelo conjugal de família.

O casamento como concretização do amor romântico carrega em si uma série de prescrições e funções, o domínio sobre as mulheres, ou mais especificamente sobre os seus corpos, talvez seja uma de suas aplicabilidades mais latentes e produtivas. Dessa forma, ser um corpo (feminino) que não está sob domínio de alguém (família, marido) e nem a serviço da maternidade, insinuando, assim, outras formas e possibilidades de existência para as mulheres fora do casamento, era desafiar uma lógica muito maior que o matrimônio:

[...] as mulheres que permaneciam celibatárias constituíram, de certa maneira, um elemento desestabilizador - pois, não apenas recusavam os novos papeis destinados a elas (como mães e esposas), mas, também, criavam condições de se constituírem em "indivíduo" para 
pleitear, de forma mais livre, os espaços de trabalho e para governar a si mesmas e a seus próprios bens; além disso, elas se tornavam exemplos visíveis da possibilidade de existência e de felicidade fora das relações conjugais (MAIA, 2011, p. 64).

Ao desafiar a lógica da família conjugal, a figura da celibatária foi atacada pelos mais diversos discursos e práticas, vista como "um problema social, por provocar uma torção num modelo naturalizado e idealizado de feminino" (MAIA, 2011, p. 24). Essas mulheres foram marginalizadas e até mesmo patologizadas. Inúmeras foram as táticas de estigmatização do celibato feminino, mas apesar de várias, todas pareciam referir-se a um aspecto em especial: o corpo. Feias, secas, frígidas, prostitutas, todas as associações e insinuações feitas às mulheres celibatárias, rebatiam no esquadrinhado corpo feminino.

Diferentemente do que ocorre como um corpo estranho que incomoda e prejudica o funcionamento de todo um organismo, a figura da mulher celibatária foi absorvida e utilizada como limite demarcador dos desvios. Michel Foucault (1999) afirma que, a partir do momento em que se descobriu que o corpo poderia ser treinado e moldado, ele passou a ser objeto de muitos investimentos e utilidades. Esquadrinhado minuciosamente o corpo poderia ser assim desarticulado e recomposto; e constantemente coagido, mais do que controlado, esse corpo seria disciplinado. Mas uma vez que a disciplinarização do corpo depende de respostas individuais às interpelações e constrangimentos a que ele é exposto, sempre há espaço para resistência, e para cada gesto resistente a punição estará presente.

É no modo de punir que comportamentos são avaliados. Numa dupla função, a punição, ao hierarquizar qualidades, recompensa e castiga, promove determinados gestos e pune inferiorizando outros. E ao traçar "o limite que definirá a diferença em relação a todas as diferenças" (FOUCAULT, 1999, p. 152-153), faz do desvio útil e produtivo. É seguindo essa mesma lógica, que a figura da solteirona é construída e posta a serviço do modelo de conjugalidade instituído pela burguesia. Como um constrangimento a posição de mulher solteira foi arquitetada; por escapar dos limites possíveis do casamento e da maternidade, celibatárias tiveram seus corpos assediados por discursos médicos, que os acusavam de 
doentes pela suposta abstinência sexual, considerada nociva ao corpo; por discursos morais que as classificavam como mulheres públicas, insinuando a prostituição e pelas inúmeras tecnologias culturais, como o cinema e a literatura, que as representavam constantemente como criaturas feias e rancorosas, ajudando a criar e disseminar a repulsa em torno das mulheres solteiras.

A figura da solteirona, conjuntamente a outros tantos discursos e práticas, que se reiteram e se apóiam uns sobre os outros, foi mais um dos mecanismos de coerção no adestramento de corpos femininos. Acoplados ao amor romântico, tais processos fizeram desse um poderoso dispositivo na constituição e funcionamento do corpo social, sobretudo em relação às mulheres que tiveram suas vidas abalizadas e mesuradas a partir das possibilidades tramadas em nome da concretização do amor romântico.

\subsection{O amor como dispositivo}

Colocar a sexualidade no domínio da produção discursiva foi uma das grandes contribuições de Michel Foucault que, ao postulá-la como algo continuadamente construído, desarticulou toda a trama que lhe garantia sustentação e sua aparente invisibilidade. Dispositivo da sexualidade foi o nome cunhado pelo filósofo na denominação dessa rede, que cobre todo o corpo social e atua por meio de inúmeras tecnologias que se reafirmam e se justificam, e nos atingem e penetram de forma minuciosa e íntima, ao ponto de o controle tornar-se um autocontrole. Ainda que o dispositivo da sexualidade atinja a todos e todas, ele não funciona da mesma forma para homens e mulheres, categorias alimentadas por ele mesmo.

A não-consideração da variável de gênero em seus estudos sobre a sexualidade é uma das críticas mais frequentes a Foucault, pelo menos por parte da crítica feminista, que diante de suas grandes colaborações não o enjeita, mas oferece uma releitura a partir das lacunas deixadas pelo 
descarte da especificidade feminina. Assim o faz Tania Navarro-Swain (2006) ao propor mais um dispositivo ${ }^{11}$ atuante na construção do feminino:

Nas fendas do dispositivo da sexualidade, as mulheres são "diferentes", isto é, sua construção em práticas e representações sociais sofre a interferência de um outro dispositivo: o dispositivo do amor. Poder-se-ia seguir sua genealogia nos discursos - filosóficos, religiosos, científicos, das tradições, do senso comum - que instituem a imagem da "verdadeira mulher", e repetem incansavelmente suas qualidades e deveres: doce, amável, devotada (incapaz, fútil, irracional, todas iguais!) e, sobretudo, amorosa. Amorosa de seu marido, de seus filhos, de sua família, além de todo limite, de toda expressão de si (NAVARROSWAIN, 2006, s/p.).

O amor, assim como o sexo e a sexualidade, foi concebido como um mecanismo de grande alcance e eficácia no processo de subjetivação e controle de mulheres. Conjuntamente ao dispositivo da sexualidade, o dispositivo amoroso, mais que ajudar a produzir corpos sexuados, iterou e fortaleceu a criação de um ideal feminino, duplamente tramando e sujeitando aspirações e comportamentos das mulheres:

O dispositivo amoroso, assim, cria mulheres e, além disto, dobra seus corpos às injunções da beleza e da sedução, guia seus pensamentos, seus comportamentos na busca de um amor ideal, feito de trocas e emoções, de partilha e cumplicidade. (NAVARRO-SWAIN, 2006, s/p.)

Como reféns do amor, as mulheres são educadas para fazer desse o protagonista de suas vidas. São compelidas a se adequar as suas demandas, a se encaixar em modelos e padrões, que as caracterizam como "doces, devotadas, amáveis e, sobretudo, amantes" (NAVARRO-SWAIN, 2013, s/p) e fazer do amor, então, sua principal "razão de ser e viver" (NAVARRO-SWAIN, 2013, s/p). O dispositivo amoroso torna-se, assim, tão central quanto o dispositivo da sexualidade, e tal como o corpo firma-se como fronteira inteligível e possível das nossas identidades, o amor torna-se, para as mulheres, o caminho factível de sua existência. Pois, ainda que pulverizados, por fatores como a emancipação feminina, os ideais do amor romântico não se dissiparam por completo, permanecem interpostos nas

\footnotetext{
${ }^{11}$ Segundo Foucault, dispositivo é "um conjunto decididamente heterogêneo que engloba discursos, instituições, organizações arquitetônicas, decisões regulamentares, leis, medidas administrativas, enunciados científicos, proposições filosóficas, morais, filantrópicas. Em suma, o dito e o não dito são elementos do dispositivo. O dispositivo é a rede que se pode estabelecer entre estes elementos". FOUCAULT (1996, p. 244).
} 
vidas das mulheres, que ainda hoje têm suas identidades atualizadas em torno do amor (NAVARRO-SWAIN, 2006, s/p.).

Adaptar-se ao tempo e suas vontades é condição elementar de existência e manutenção do dispositivo amoroso que, sob novos imperativos, subsiste aos anos e elabora novas, ou apenas repaginadas, sujeições. Livros de etiqueta e colunas de jornais que ensinavam mulheres a se comportar, ser uma esposa dedicada, tirar manchas e fazer um bom cozido, foram apenas substituídos por demandas nem tão díspares assim. Mesmo o casamento e a maternidade, já não tão limitados e limitantes como no passado, perduram como parâmetros de julgamento das mulheres, que agora ocupam mundos, antes segmentados, o doméstico e do trabalho. Lembrando que as mulheres a que me refiro aqui são as mulheres brancas, urbanas, de classe média, que são as sumariamente representadas na coleção; pois mulheres pobres e negras quase sempre tiveram que trabalhar e pouco ou nada foram poupadas em razão de seu gênero.

De forma bastante insidiosa, as conquistas alcançadas pelas mulheres são absorvidas e adaptadas, e num movimento contrário, postas a serviço da mesma estrutura patriarcal que tinham como alvo a ser desarticulado. E por mais que hoje, as mulheres transitem e ocupem diferentes espaços e posições, sua imagem, o dito feminino, sofreu poucas ou não muito efetivas transformações. Os dispositivos amoroso e da sexualidade subsistem vigorosos na construção e disseminação desse feminino, que agora adaptado as novas demandas, ergue-se sob dois eixos aparentemente incompatíveis. Sexo-trabalho-autonomia e Amormaternidade-dom-de-si são os nomes dados por Tania Navarro Swain (2013, s/p) na busca pela compreensão e desarticulação de tais eixos, que por correlacionarem atributos não tão afins, perfazem um feminino contraditório, mas nem por isso falho.

Num movimento de oposição em que a inserção no mundo do trabalho e do desejo de autonomia entram em choque com os apelos da maternidade; e a liberdade sexual faz frente ao desejo de uma união estável, a figura da "mulher moderna" é paradoxalmente construída. Delineada por exigências divergentes, as escolhas das mulheres são incitadas não só por uma série de deveres como são acompanhadas de diversas culpabilidades. 
Escolher não ter filhos ainda é considerado um transtorno, mas dedicar-se apenas à casa e aos filhos é tido como uma mediocridade; fazer sexo antes do casamento já não se configura um defeito de caráter, todavia possuir muitos parceiros é algo estritamente condenável. Manobrado e estremado, o poder de autogestão das mulheres é confinado dentro de possibilidades, que podem não mais se limitar à conjugalidade e ao modelo de maternidade nela embutido, mais ainda coagem mulheres e meninas a adotar determinados modelos, urgências e posicionamentos.

Diante de tudo o que foi exposto, escrever sobre o amor não pode ser considerado tarefa despretensiosa e acredito tornar-se ainda mais árdua quando feita sob encomenda e sob a latente problemática de gênero embutida nos recortes da coleção. Difícil pensar que mesmo as escritoras não engajadas com a crítica e/ou movimento feministas não tenham minimamente refletido sobre as representações que construiriam a partir de tais recortes, que quando juntos, ganham contornos ainda mais fortes e discutíveis.

A literatura, como uma forma de expressão privilegiada, tem o poder de, no trabalho com a linguagem, criar ou reforçar sentidos. Dessa forma, ainda que o amor, em seu sentido clássico-burguês, apareça com uma das armadilhas que ajudaram a trancafiar mulheres em seus corpos e casas; na literatura, amores, corpos e casas abrem-se para um universo de possibilidades e configurações. Aparentemente multifacetados, como sugerem a orelha de apresentação das obras e seus subtítulos, os amores representados na coleção trazem narrativas de amor que sobrevivem ao tempo, que sucumbem diante da rotina, amores hipotéticos, incorpóreos, proibidos, fracassados; mas, ainda que as narrativas sejam escritas a partir de diferentes extremos, a multiplicidade investigada concentra-se nas possibilidades de gênero construídas por essas sete escritoras, e se suas obras, se, conjunta e/ou individualmente, caminham ou não para a formação de uma consciência feminista, no sentido de apresentarem corpos e amores que escapam à lógica patriarcal.

São pelos escapes e manobras (ou pela ausência desses) que me interesso e que debruço minha investigação, por meio da análise literária de cada obra da coleção, pois acredito que a literatura, além de ser o lugar do 
estético, possui uma dimensão política que lhe confere não só o poder de legitimar e sedimentar sentidos como faz dela também território de contestação desse mesmo aspecto.

Seguindo uma ordem que vai da narrativa mais tradicional, em relação aos papeis de gênero dentro das relações amorosas, para aquelas que de alguma forma desafiam determinadas prescrições que normatizam tais comportamentos, estruturo as análises literárias das sete obras da coleção. Num primeiro momento, trago as quatro obras mais conservadoras da coleção.

\subsection{Amor e romantismo ${ }^{12}$}

Acompanhado do subtítulo "Amor e romantismo", Recados da lua (2001) traz amores que enfrentam desgastes do tempo, que sobrevivem a suspeitas de traições e superam diferenças. É a faceta vitoriosa e soberana do amor, típica do amor romântico, que a autora exibe em sua narrativa. Reiterado no trabalho com a linguagem que, por meio de metáforas e descrições romantizam cenas cotidianas e suas ações prosaicas, o romantismo pode ainda ser observado em outras dimensões da narrativa. Porém, apesar de múltipla e abrangente, a concepção de romantismo, em Recados da Lua (2001), parece permanecer limitada à sua noção mais reducionista.

Amores cotidianos entremeados por versos eróticos, assim é composta a narrativa de Helena Jobim que, no intuito de falar sobre o amor, traz a história de Dora e Ricardo, casal de meia-idade que tem a vida conjugal estremecida quando ela vence um concurso literário com poemas eróticos dedicados a um jovem de nome Core. É com o mesmo tom lírico, presente nos versos de Dora, que Jobim narra os dilemas e afagos dos cônjuges. Eles partilham as páginas com mais dois casais, Ângela e Val e Jurema e Jair, que enfrentam diferentes impasses, mas anseiam pelo mesmo propósito: realizar-se no amor.

\footnotetext{
${ }^{12}$ Cada uma das sete obras da coleção Amores Extremos possui além do título, um subtítulo. Como um elemento de conexão entre as obras, analiso as narrativas também a partir da especificidade sugerida pelo subtítulo, uma vez que são também paratextos na teoria de Genette. "Amor e romantismo" é o subtítulo de Recados da Lua.
} 
Tendo como foco a representação dos papeis de gênero, centro minha leitura e análise da narrativa na construção dos relacionamentos amorosos das personagens femininas. É a partir de como essas mulheres, totalmente imersas em suas relações, experienciam e interpretam o amor, que busco compreender e problematizar as possibilidades de gênero delineadas na construção da narrativa.

\section{Dora e Ricardo}

Como uma típica personagem feminina do romance brasileiro contemporâneo $^{13}$, Dora é uma mulher branca, heterossexual e dona de casa. Casada há vinte anos com Ricardo, alto executivo, vive uma relação já desvanecida pelo tempo e pela rotina. E se antes, a crise conjugal aproximava-se de forma silenciosa, paulatinamente a cada refeição e ritual cotidiano, depois que Dora vence o concurso "Novos Poetas" com seu livro Core, vinte poemas de amor, a crise ganha corpo, vigor e até mesmo nome: Core.

Negligenciada por Ricardo, absorvido pelos negócios e suas oscilações, Dora, numa de suas frequentes noites de insônia passadas ao lado do marido, que dormia quase sempre anestesiado por uma dose de uísque, atreve-se a escrever poemas eróticos e despretensiosamente resolve enviá-los a um concurso. Durante um corriqueiro café da manhã, ela e o marido, que nem sabia de tal atividade criativa da esposa, tomam conhecimento, por meio de uma nota no jornal, de sua vitória no concurso. Estarrecido com o que lia a respeito dos versos de Dora, Ricardo a cobre de perguntas, julgamentos e acusações:

Então agora você escreve poemas eróticos? A matéria diz que o livro é dedicado a um jovem. [...] Acho ridículo. O que pensarão nossos amigos? E nossa filha? [...] Por que sua fantasia é com um adolescente? E quem é Core? [...] Você ainda não respondeu à minha pergunta. Que palhaçada é essa de concurso? (RDL, p. 22) $)^{14}$

Admirada e surpresa por seu feito, Dora não responde às perguntas do marido, apenas the devolve acusações, "você nem toma mais

\footnotetext{
${ }^{13}$ Ver DALCASTAGNĖ, R. "Representações restritas: a mulher no romance brasileiro".

14 As referências retiradas do romance Recados da lua serão citadas pela sigla RDL, seguida do número de página.
} 
conhecimento da minha existência e fica furioso porque escrevi versos". Se, para Dora, a crise conjugal já se instaurava há um tempo, para Ricardo, ela só se torna presente e perceptível com a publicação do livro de sua esposa. Alvejado pelos versos de Dora, dedicados a um jovem de dezoito anos, Ricardo, motivo de chacota de seus colegas de trabalho, que "viviam agora brincando com ele a respeito da matéria que saíra nos jornais sobre o livro de Dora" (RDL, p. 107), passou a viver assombrado por todas as possíveis pressuposições de insatisfação e infidelidade imaginadas a partir dos poemas de sua mulher. Com sua "virilidade" ferida, Ricardo parece, então, enxergar os desgastes e atrofiamentos da relação.

Interpostos aos capítulos da narrativa, dispostos em forma de prosa e identificados pela grafação em itálico, os poemas de Dora, numa mistura de delírio, súplica e declaração de amor, trazem um eu - lírico feminino que clama pelo jovem Core, que aparece delineado numa mistura de lembranças e miragem:

... sonho e sei que sonho, te amo mais do que Deus permite, Core me disse um dia, ele vai me dizer, e deitamos na areia fria que já não sinto, e nossos beijos, nosso beijos, por um tempo sem tempo, conheço o prazer em seus braços, meus olhos se fecham, meus dedos afagam seus cabelos, tateiam seus olhos também fechados, acompanham o contorno perfeito de sua boca [...].(RDL, p. 26)

Os versos são recheados de metáforas e sinestesias que constroem um erotismo diluído, insuflado, quase incorpóreo:

... e o mar respirava, calmo, suas águas ressonavam mansas, quase escuras agora, que momento existe senão este que se repete, se repete, mas de que cor são seus olhos, você me perguntou, e você mesmo respondeu, são violetas encharcadas, aquele silêncio colhido no rosto amado, essa ardente expectativa, nada pode me afastar de você, e suas mãos conheceram outra vez meu corpo... (RDL, p. 52)

Os versos já nos são apresentados, pela nota do jornal e pelos seus primeiros leitores/leitoras, sob o rótulo de erótico. Isso nos possibilita pensar na concepção de erotismo movimentada pela narrativa. O erótico nos poemas de Dora é alusivo, evita minúcias e pormenores dos intercursos sexuais e concentra sua força expressiva nas sensações sentidas além corpo:

e a brisa que chegou de repente enfunou velas em meus ouvidos [...] meu gesto de entrega e o riso que demorou na boca, vem, querida, vem, e enquanto você falava era como se fosse eu, meu coração 
respondia apressado no peito, sim, sim, o ar renovado, a maresia, o mistério das pálpebras fechadas, essa última luz vazando o rosto... (RDL, p. 51)

Alimentado talvez pelo limite distintivo entre erotismo e pornografia, em que esta, equivocadamente igualada ao sexo e à nudez faz da materialidade do corpo aspecto minimamente arriscado, o erótico representado em Recados da lua (2001) simula a sexualidade. Travestidos por cores e movimentos do mar e do ar, corpo e sensações são resguardados. O risco de aproximar-se do pornográfico parece, assim, pesar sobre a escrita de Dora.

Difícil imaginar que por tal erotismo Ricardo se abalaria tanto. Afinal, está em Core sua maior irritação e insegurança. Na procura por respostas e razões que justificassem a suposta traição de Dora, ele a questiona a respeito do momento no qual ele teria lhe ele the faltado para que ela precisasse de outro e, mais uma vez, sente-se atingido pela resposta de Dora. Apesar de várias insensibilidades dele apontadas por ela, só aquela que diz respeito ao seu desempenho sexual parece lhe entrar nos ouvidos:

O que é que faltou em nossa vida, Dora? Quando eu te faltei? Ela responde com tristeza: - Era tudo tão diferente. A delicadeza, entende? A cumplicidade, as concessões mútuas... Você fechou a sua sensibilidade. Até o sexo, que era tão bom, tornou-se uma coisa quase mecânica. Ricardo, ofendido: - Quer que eu volte a ter dezoito anos como o seu belo rapaz? (RDL, p. 66-67)

E, do seu lugar de provedor, ainda argumenta que a vida confortável e luxuosa que hoje eles têm deve-se à dedicação incansável dele aos negócios, e que ela não teria do que se queixar. Instalada a presença de Core, Dora e Ricardo passaram a discutir cada vez mais e por coisas pequenas e frívolas. Assistindo ao desgaste de sua relação, Dora recorda-se da mãe, "Ela suportava tudo", e rejeita para si tal comportamento, "Mas eu não quero isso para mim" (RDL, p. 36). Porém, apesar de recusar-se explicitamente ao típico papel de boa esposa que tudo releva e supera, Dora aparenta permanecer presa a um modelo (atualizado) de esposa, que ainda segue um roteiro e obedece aos protocolos de beleza e educação:

Tinha de enfrentar o momento que estava vivendo. Pentear-se, maquiar-se, voltar para um almoço em que tudo deveria sair bem. Principalmente ela. Atender a todos, dizer frases polidas e inteligentes. 
Responder sobre o grande crime que tinha cometido. Versos de amor, de paixão. Devia ficar fria, rir talvez. Não deixar espaço para comentários futuros entre os amigos do marido. (RDL, p. 36)

Descrita como uma mulher de "cabelos ruivos, fartos e ondulados. [...] de pernas compridas e bem torneadas, [...] de rosto exótico que chamava a atenção das pessoas"(RDL, p. 87), que não aparentava ter a idade que tem, como bem salienta a filha, "Você não parece ter nem trinta e é linda... sempre pensa que somos irmãs..."(RDL, p. 72), Dora é construída como uma mulher muito bonita, beleza essa reconhecida, vangloriada e usufruída pelo marido. Sempre presente nas colunas sociais, sob a repetida legenda "casada com o industrial Ricardo Donne", desempenhando, com maestria, e aos olhos de Ricardo, a função de esposa de um alto executivo, todavia quando Dora passa a ser conhecida e reconhecida por seu livro, seu êxito perturba o marido: "Ricardo sabia muito bem da beleza de sua mulher, e isso sempre o deixava orgulhoso. Mas nessa noite o sucesso dela o incomodava" (RDL, p. 88).

O incômodo gerado pela obra de Dora ultrapassa as paredes de sua casa. Se de alguma forma o ato de escrever, para as mulheres, ainda é considerado um atrevimento, como já discutido, escrever poemas de amor figura uma petulância de menor grau. Porém, ao escrever poemas de amor, sob um viés erótico, parece fazer de Dora uma espécie de ameaça. Alípio, editor de seu livro, a julga corajosa e diz que, "com os poemas que escreveu, está se jogando às feras" (RDL, p. 47). Apesar da aparente audácia contida nos versos escritos por Dora, quando olhamos para os trechos transcritos na narrativa e todo o contexto em que foi produzido, ou ainda recebido, já que Dora afirma que os versos vieram até ela, "Foi numa das minhas noites de insônia. Esses versos chegaram até mim..." (RDL, p. 21), eles já não possuem tanta temeridade.

Dedicados a Core, que é efetivamente Ricardo, a maior pulsão contida nos poemas de Dora está na tentativa de resgate do marido para dentro da relação. Reavivar momentos e promessas desvanecidos pelos anos em forma de poesia foi o gesto perpetrado por Dora na salvação de seu casamento, função essa tradicionalmente incumbida às mulheres. $E$ apesar de seu premiado e elogiado feito, num momento em que ela e o 
marido trocam confissões e pedidos de desculpa, Dora diz ter agido errado, que deveria ter lutado pelo casamento de uma outra forma:

- Eu morreria sem você, Dora. Não ia saber o que fazer de minha vida se você me deixasse. Fui desatento ao nosso amor. - Fomos desatentos, Ricardo. Eu também poderia te buscar de outra forma para que você voltasse pra mim. Também fui cega. Paguei caro... sofri muito.(RDL, p. 150)

O fato de Dora isentar-se de uma autoria empenhada e consciente, e creditar seu único propósito para tal feito ao resgate do casamento, apesar de sentir "uma satisfação interior plena"(RDL, p. 48), ser por vezes elogiada e ter seus versos considerados como "pura literatura" (RDL, p. 104) repisa uma velha questão, aqui já abordada, de que as mulheres só escreveriam sobre si mesmas, e ainda tonifica a centralidade e o peso das questões amorosas na vida e nas escolhas das mulheres.

\section{Ângela e Val}

Ângela e Val são o primeiro casal a quem somos apresentados na narrativa. Ela, filha de Dora e Ricardo, estudante universitária do curso de Artes, entre seus dezoito e vinte anos, namora Antônio Valério, ou simplesmente Val, jornalista, recém-divorciado, pai de uma menina pequena. O obstáculo mais evidente da relação entre os dois é a diferença de idade e todos os descompassos provindos dela. Apesar de a diferença em si não ser contestada ou vista como um problema, a relação entre Ângela e o namorado é construída a partir dos limites e possibilidades regidos por tal parâmetro.

Assim como Dora alimenta o frequente padrão de personagens femininas na literatura brasileira, Ângela reitera a típica imagem de uma garota moderna, que sob os incompatíveis eixos do dispositivo amoroso, tem de aprender a lidar com o inevitável desejo do amor romântico e suas reais possibilidades, que misturadas a outras tantas aspirações, nem sempre mostra-se compatível a sua realização. Dividida entre as expectativas e rompantes típicos do amor romântico e suas reais e imperfeitas possibilidades de concretização, Ângela é construída como uma 
personagem ambivalente. Constantemente censura seus pensamentos e ações:

A melhor coisa deste mundo é ir ao encontro dele, pensa. E pensa ainda: 'Eu sei que é bom. Se um dia isso tudo acabar ... Pelo menos eu sei agora que é bom. Desde o momento em que ele telefona e começo a me arrumar... (RDL, p. 9)

O coração bate forte, 'se um dia ele me deixar, acabo com a minha vida'. E terminou assim o pensamento: 'Como sou ridícula'. (RDL, p. 10)

E se esforça para ter uma postura realista diante de seu relacionamento, como ocorre quando é coagida por sua amiga, Joyce, que a alerta da fama de conquistador de Val:

Joyce fez um muxoxo: - Hum... Cuidado com ele. [...] É muito mulherengo. Ângela riu: - Não estou preocupada com isso. Nos damos bem. - Dou a maior força... mas presta atenção pra não se machucar. - E onde é que você não se machuca? Joyce olhou-a um pouco surpresa. - Você sente assim, é? - e caçoando, sem maldade: - Tão jovem e já tão desiludida... — Sou realista, isso sim. - Além de mulherengo, ele está se divorciando e tem uma filha. Você está arrumando sarna pra se coçar. - E você está careta, falando igual a meu pai e minha mãe. (RDL, p. 28-29)

Embora apareça como uma garota moderna e liberal, que acusa a amiga, que a repreende, de "careta", que não vê problema em ter um relacionamento afetivo e sexual com um homem mais velho, Ângela também é vista como uma menina tímida, nas palavras de Val: "uma rolinha assustada"(RDL, p. 135), que ainda enrubesce quando Val a encara ou menciona qualquer fato mais íntimo sobre os dois, "Por que de repente você fica assim tímida? [...] Nem parece aquela moça que se deita comigo... Atrevida, fogosa, selvagem. E agora você ficou vermelhinha!" (RDL, p. 11), e que ainda se auto-avalia como imatura e se culpa por não saber lidar com a filha do namorado, "Ela é muito agarrada com o pai. Mas sou eu, mãe ... sou eu que não consigo dividir o Val com ninguém. [...] Acho que sou muito imatura, mãe. Uma estudantezinha insegura e possessiva" (RDL, p. 71).

A diferença de idade e os descompassos de experiências existentes entre Ângela e o Val, salvo esse seu breve comentário que, decepcionada com a mudança de seus planos por causa da filha do namorado desabafa com sua mãe, não são tratados como problema substancial. O pai de Ângela é o único a opor-se abertamente ao relacionamento da filha, mas não por 
razão da idade, como um homem de negócio que é, Ricardo acusa Val de ser "um homem sem ambição" (RDL, p. 23) e coloca o fato de ele ser divorciado e ter uma filha como problemas secundários, "Além do mais, é divorciado. [...] e ainda existe uma criança nessa história" (RDL, p. 23-24).

Introjetada na diferença entre os sexos, a diferença de idade entre Val e Ângela é atenuada na narrativa. Características como timidez, insegurança e romantismo, tradicionalmente associadas às mulheres, delineiam pensamentos e comportamentos de Ângela, que não é vista necessariamente de uma forma infantil, mas é construída como uma personagem que repisa estereótipos de gênero. Ainda que racionalize sobre suas emoções, suas ambições e desejos mais íntimos repousam sobre um estado de amor romântico e eterno: "Queria ficar assim a vida inteira. Não me conformo com esta outra realidade. Só isso. Queria ficar era lá. Lá é que é bom. Aqui a gente se machuca muito." (RDL, p. 56).

Mesmo que saibamos que Ângela estuda, nada nos é contado a respeito de suas escolhas futuras ou mesmo projetos presentes, é no encontro com o namorado o seu momento supremo, "Hora de ver Val, hora de sentir-se viva" (RDL, p. 30), ao passo que o namorado, que está a escrever um livro sobre Jair, namorado de Jurema, declara que é em seu escritório "onde me escondo. Onde trabalho. Onde às vezes penso que sou feliz" (RDL, p. 135). Construir tais realizações reitera a velha divisão entre público e privado trabalhada por Giddens (1993) em sua teoria acerca da intimidade, em que as questões públicas, como o mundo do trabalho, seriam de responsabilidade dos homens, que ali se realizariam e comprovariam o seu valor e felicidade; e o zelo do mundo privado, das mulheres, mensuradas e consideradas "bem sucedidas" somente a partir de sua realização no relacionamento.

Ângela, apesar de construída como uma garota diferente, que enxerga as coisas de um modo particular e especial, como declara seu namorado, tem sua narrativa pessoal restrita aos termos e possibilidades delimitados pelo dispositivo amoroso.

Você é uma mulher diferente. - Diferente em quê? - Ainda não sei. Mas que é diferente, é. Até essa flor que você tem na mão é diferente.

- Desde pequena pego essas flores. Não parece que derramaram 
vinho escuro no cálice? - Acho que ninguém pensou nisso antes. Eu mesmo nunca tinha reparado nessas flores tão singelas (RDL, p. 31).

Quase como uma personagem de chick $l i t^{15}$ que tem como elemento mais importante de suas vidas, a relação amorosa, Ângela aparece alimentando um antigo padrão que parece apenas ter se modernizado.

\section{Jurema e Jair}

Empregada na casa de Dora e Ricardo, Jurema vive com Jair, ou Bonito, como é conhecido no Morro do Cachorro por causa dos olhos verdes, desempregado, ele faz bicos sempre que possível. Assombrada por uma traição antiga de Jair, Jurema vive sob a ameaça de um novo deslize da parte do companheiro, e quando num jogo de búzios, sua amiga, Oswaldina, vê a sombra de uma mulher de riso debochado sobre a vida dela e de Jair, Jurema tem seus dias e pensamentos revirados.

Descrita como uma mulher negra,"bonita, alta, de canela fina [...] cabelo pixaim [...] de olhos rasos e africanos" (RDL, p. 126), Jurema é pintada como boa parte das personagens secundárias, não é só menos caracterizada na narrativa, como tem sua representação extremamente estereotipada e até mesmo preconceituosa, como o uso do termo "pixaim" na descrição dos cabelos crespos de Jurema. Empregada, negra, moradora da favela, bem quista pelos patrões, em nada Jurema escapa do pisado modelo de trabalhadora doméstica, e até mesmo naquilo que a une às outras mulheres da narrativa é, de várias formas, diferenciado.

$O$ tratamento diferencial da linguagem é um dos indícios de distinção das personagens, enquanto Ângela, no primeiro trecho a seguir, ao olhar para o namorado tem seus pensamentos transcritos com termos cheios de adornos e detalhes, Jurema, ao concentrar-se em Jair para o jogo dos búzios, tem sua memória traduzida de forma mais econômica, não só no que diz respeito à extensão do fragmento, como também na especificidade e quantidade de adjetivos:

\footnotetext{
${ }^{15} \mathrm{O}$ chick lit seria a literatura direcionada a mulheres, urbanas, profissionais, às voltas com seus problemas amorosos e sexuais. Ver LEAL, As escritoras contemporâneas e o campo literário brasileiro: uma relação de gênero.
} 
E olha cada detalhe do seu rosto dourado, mouro. Os olhos cor de mel são muito doces. O nariz, quase adunco, mouro. Seus dentes brancos e grandes, os lábios sensuais. Os cabelos com caminhos ondulados, mouros. As orelhas pequenas, coladas à cabeça, transmitem sensualidade. (RDL, p. 54-55)

Jurema fecha os olhos, pensa com força no seu homem. Pensa em seu peito forte, glabro, a pele escura. Vê seus cabelos crespos, cortados sempre rentes, os olhos verdes.(RDL, p. 16)

A diferenciação decai também sobre o tipo de dilema enfrentado pelas personagens. No tempo em que Dora enfrenta uma crise conjugal em razão do distanciamento do marido, Jurema teme perder o companheiro para outra mulher. Enquanto Dora tem insônias e copiosas crises de choro, e impulsionada por esse sofrimento, escreve vinte poemas que exploram e rememoram seus sentimentos e angústias, Jurema reza para São Judas, faz promessas e tem sua súplica elaborada em algumas linhas, a mostrar pouco espaço e complexidade à crise conjugal da segunda personagem:

Entretanto, se dentro da narrativa, o drama de Dora aparece com mais nuances e complexidade, aos olhos de Jurema soa quase como algo sem sentido comparada à ameaça que enfrentava:

Percebeu que sua patroa tivera insônia outra vez e que isso tinha a ver com a discussão que tivera como Dr. Ricardo. Adivinhava que tinham brigado por causa de uns versos que ganharam um concurso. Pensou em seu homem, e na diferença entre as duas. Ela, assombrada com os búzios, temendo perder Jair. E D. Dora, a quem servia há tantos anos, angustiada por causa de umas coisas escritas e elogiadas por muita gente. Sabia disso por causa dos telefonemas que a patroa havia recebido. (RDL, p. 34)

Apesar da afirmação de cumplicidade existente entre as duas, pelo narrador/narradora, é somente Jurema que aproxima e compara seu dilema amoroso ao da patroa. Dora, mesmo a perguntar Jurema sobre Bonito, não estabelece relação entre as situações:

- Não queria que a senhora estivesse triste hoje. Dora sorriu palidamente. Havia entre as duas uma cumplicidade. - É, Jurema. Mas você também parece triste. Já sei que Bonito aprontou alguma... - Os búzios não foram bons pra mim, D. Dora. - O que eles disseram? Que ia aparecer uma sirigaita na vida do Jair. E pelo que sei, já apareceu. - Eu acredito nos teus búzios... Mas pode ser que o Bonito não os siga. E não precisa jogar búzios pra saber que ele te ama, Jurema. - Pára de falar, pensativa, depois continua: Eu também queria que alguém jogasse búzios para mim (RDL, p. 34-35). 
Restrita aos serviços domésticos e a sua relação com Jair, que é tão estereotipado quanto a companheira, Jurema aparece pouco caracterizada, fora descrições físicas e sua preocupação constante com Jair, pouco ou nada sabemos sobre ela, idade, ambições, planos não são mencionados. $\mathrm{E}$ embora seja a única personagem que testemunhe todos os três dilemas trazidos pela narrativa, por estar sempre no espaço da casa, atendendo telefones e observando em ações diárias que as coisas não iam bem, o olhar de Jurema é pouco aproveitado.

Percalços enfrentados, todos no livro alcançam o prometido e persistente final feliz. Ricardo, com ajuda de um velho amigo, relembra seu apelido, Ricardo Coração de Leão, e por associações e lembranças dos versos de Dora, finalmente vê que ele é Core e tira férias românticas com sua esposa; Ângela cede ao seus rompantes mais românticos e aceita o convite de ir morar com o namorado e Jurema descobre que a sombra da mulher vista nos búzios, ainda que uma ameaça a vida de Jair, nada tinha a ver com traição. Todos os três casais terminam, assim, em paz, e como uma forma de união entre suas histórias, sob a luz da lua cheia.

De final e construção pouco ou nada surpreendente, Recados da Lua (2001) mantém-se preso a discursos que ainda constroem mulheres nos limites do amor. É o amor como elemento central e realizador na vida das mulheres, típico ideal do amor romântico, que aparece na narrativa, que mesmo quando apresenta uma aparente quebra a esses ideais da faceta romântica no amor, ao trazer poemas classificados como eróticos para o centro da narrativa, permanece restrita aos termos e fronteiras concedidos pelo amor romântico e a estrutura de gênero nele incorporada.

O erótico, afirma Lúcia Castello Branco (1984), por carregar em si uma capacidade de revolver ou ainda desmascarar certa hipocrisia que circunda os relacionamentos e a ordem social a que ele responde, constitui uma força poderosa no enfrentamento e questionamento dessa mesma ordem. Porém, como um termo abrangente e cheio de nuances, nem sempre é conduzido com esse propósito. A noção vinculada e defendida na narrativa, levantada a partir dos indícios da escrita de Dora, pouco explora 
as possibilidades do erotismo, nos traz um erótico implícito, asséptico e recatado.

Em seu texto, "Eros enunciado", Silvana Carrijo (2008) chama atenção para o fato de como nós, mulheres, temos, desde muito cedo, nosso vocabulário assaltado, de como, não só determinados assuntos, mas também o pronunciamento de determinados termos nos são vetados, isso se quisermos ter nossa probidade feminina ilibada. Dessa forma, construir um erotismo sussurrado, cheio de dedos e meias palavras, saturado por termos e construções líricas, e preso às sugestões, talvez por acreditar que assim o erótico deva ser, como ocorre na obra de Jobim, é consentir e reforçar um duplo interdito, que nos atinge não só no acesso à palavra como num exercício pleno de nossa sexualidade.

A linguagem poética, presente não só nos versos de Dora, como na própria narrativa de Helena Jobim, parece, então, estar a serviço dessa depuração, ganhando mais espaço na narração à medida que corpos se aproximam e se entrelaçam, e perdendo intensidade na descrição de cenas e encontros cotidianos, como ocorre no encontro de Ângela e o namorado, que são praticamente teletransportados do bar em que estavam para uma outra dimensão à medida que carícias são trocadas:

- Vamos sair daqui. E não ouviram mais os ruídos do bar. Penetravam outra vez naquele espaço só deles, construído pelos seus encontros, seus gestos, seus corpos juntos. E em outra dimensão caminharam, de mãos entrelaçadas, olhares intensos e meios sorrisos, penumbra e luz, arfar, suspiros, gemidos, desejo, prazer. Pensamentos, palavras, emoção, êxtase. Depois silêncio (RDL, p. 13).

É como um indicador de proporções físicas, dadas sumariamente pelo/pela narrador/narradora, e como um veículo de representação dos encontros sexuais das personagens que o corpo aparece em Recados da lua (2001). Descritos em poucos períodos, muitas vezes apenas sugeridos, esses intercursos trazem corpos e sensações abreviadas. Como num filme de Hollywood, em que o sexo não envolve barulhos nem secreções, o corpo, tal qual o erótico evocado pelas poesias da personagem do romance, aparece, ainda que descrito e despido, empregado de forma rasa e genérica.

Beija-a muito. Com extrema delicadeza. Começa num leve roçar de lábios e cresce de intensidade. Sua mão toma seu pescoço delgado, e suas bocas se juntam num momento de paixão. Seu outro braço the 
toma a cintura, primeiro levemente. Depois, cola seu corpo com força ao corpo dela. E ela se entrega, inclinada de prazer. Ele puxa-a para o sofá e se amam com sofreguidão (RDL, p. 13).

Entremeados, corpo feminino e masculino diferenciam-se por, além do uso dos pronomes, que identificam quem pega, quem toma e quem beija, pelas ações que cada um desses corpos pratica, enquanto ele, ativo e proativo, toma pescoço e cintura e cola seu corpo no dela, a ela, só cabe a entrega. A última cena do livro é bastante emblemática nesse ponto, num trecho de muitas descrições, Dora e Ricardo, num barco, fazem sexo, ela, totalmente entregue e tomada e absorvida pelo amor, chega a desaparecer. Coberta pelo corpo do marido, Dora chega a ser despersonalizada pela imensidão que o amor ocupa em sua vida: "A lua cheia sobe ao céu por trás da mata ilumina seu corpo, como se fosse prata. Seus lábios se colam e seu corpo de homem e seu corpo de homem rola sobre o dela até cobri-la por inteiro" (RDL, p. 154).

Mais que ambientar e conduzir nossas leituras, descrições físicas e práticas sexuais, ao contornar o corpo e demarcar certas características e ações como masculinas ou femininas, promovem determinadas identificações, que mostradas em reincidência, são travestidas de verdades incontestáveis. E trazer um corpo feminino editado e subserviente ao gesto masculino é, ainda que de forma sugestiva, reforçar o traçado das diferenças entre os gêneros.

O tratamento sugestivo dos corpos e da sexualidade parece ser reiterado e justificado na escolha da capa que traz o quadro Gabrielle com estojo de jóias (1910) (fig. 1), de Pierre-Auguste Renoir como ilustração. Uma mulher, de pele muito branca e cabelos muito pretos, enfeita-se à beira de uma penteadeira. Vestida com uma espécie de penhoar que nos permite entrever seus seios, Gabrielle olha-se despretensiosamente no espelho. Quadro do pintor impressionista Renoir, Gabrielle com estojo de jóias traz características muito próprias da pintura de seu tempo. O Impressionismo, como um movimento que buscava traduzir impressões tais quais foram percebidas, em nome da supremacia dos sentidos, abriu mão de técnicas e princípios tradicionais da pintura, que já não encontramos em Gabrielle. 
Contornos imprecisos, pinceladas rápidas e cores de pouco contraste são algumas das características presentes nas obras impressionistas, que no intuito de capturar os aspectos mais efêmeros e fugazes, tornaram-se indispensáveis ao gesto ligeiro e sensorial. Em Gabrielle com estojo de jóias, pintado na última fase de Renoir, já bem debilitado por conta de uma artrite, a palheta de cores já encontra-se reduzida. De predominância alaranjada, a sutileza cromática da composição só é interrompida pelo escuro dos cabelos, como podemos observar, de tons muito próximos, mão, flor e fundo quase se fundem no mesmo tom cor de laranja. Bastante iluminado, o quadro já não possui o efeito dramático do abolido chiaroscuro, tão presente nos quadros renascentistas; sombras e volumes são sugestionados por tonalidades claras, muito próximas das cores que as dimensionam.

É o gesto leve e espontâneo o ansiado e representado no quadro de Renoir, que pinta Gabrielle como se a observasse sem a sua percepção ou consentimento, à espreita do instante e movimento mais genuíno e natural. Cômoda, em seu ambiente, Gabrielle observa-se sem muita pretensão; a nudez, ainda que notória, aparece de modo fortuito, como se causada pelo deslize do tecido, o que ajuda a criar uma sensualidade latente, ainda que haja uma nudez exposta e muito presente. Esse sugerir, mas não efetivamente mostrar, que no quadro aparece não só no movimento, mas sobretudo na técnica, parece também estar presente na narrativa, principalmente na construção e descrição dos corpos e dos encontros sexuais, em que o tom lírico ganha ainda mais força e as sentenças tornamse muito mais sugestivas do que reveladoras.

Diferentemente do que ocorre no quadro, em que Gabrielle contempla a si mesma, e com o olhar voltado para o espelho quase se isola naquele instante, as personagens de Recados da lua (2001) pouco ou nada se olham, são mulheres absorvidas por suas relações amorosas, não há sequer um momento em que elas lidem apenas com elas mesmas, nenhum instante íntimo ou mesmo banal que o único reflexo de seus pensamentos tenham somente elas como imagem refletida. 


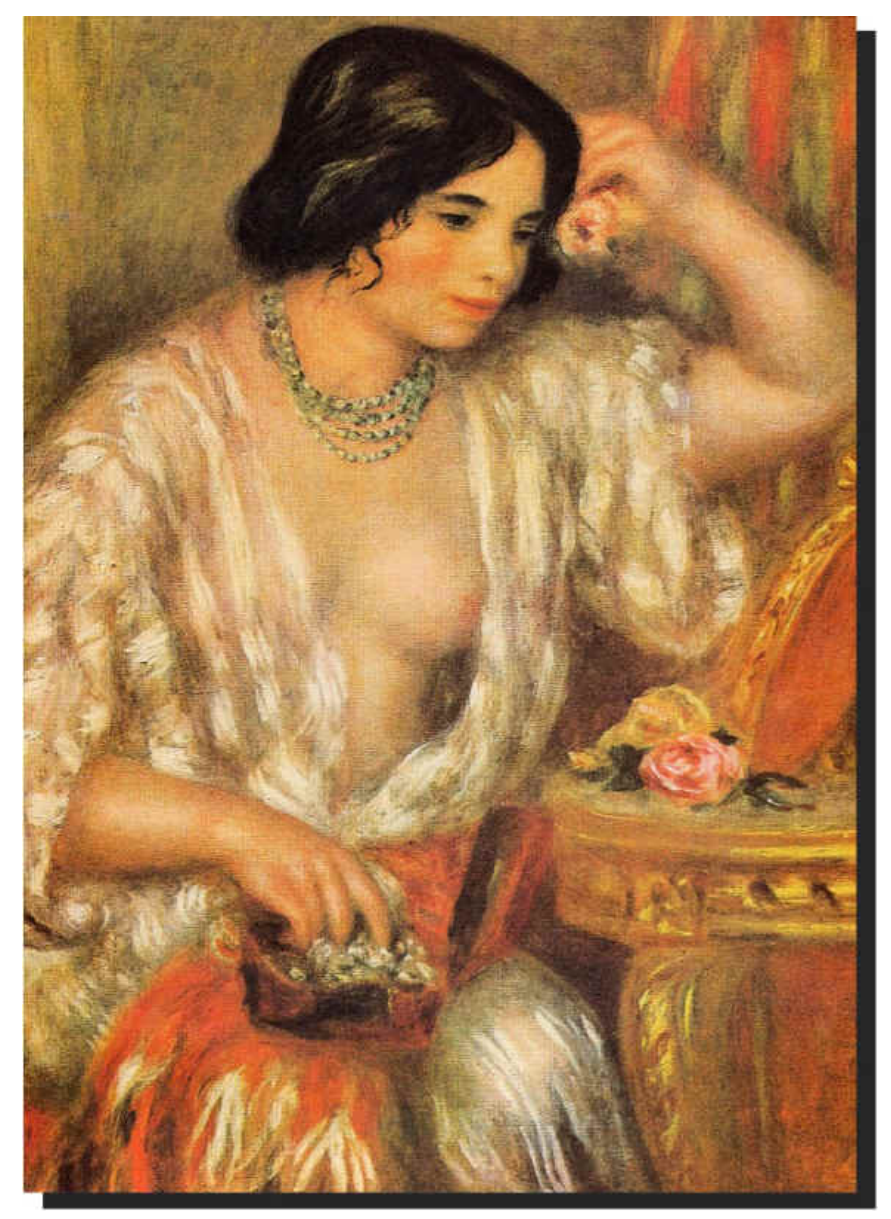

Figura 1 - Gabrielle com estojo de jóias (1910), de PierreAuguste Renoir

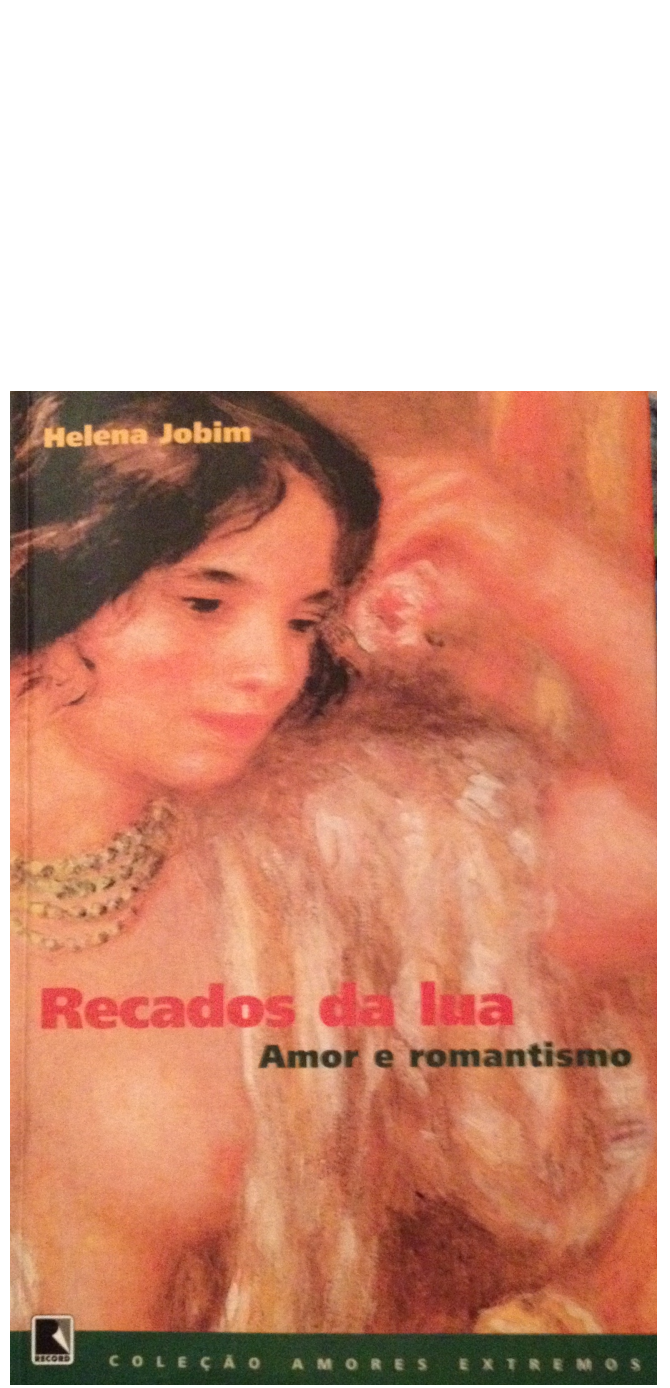

Figura 2 - Capa de Recados da lua

É ao abrigo do "anjo do lar" que Helena Jobim parece escrever Recados da lua (2001). Presa a um modelo romântico-burguês de amor, logo conivente com o jogo e a estrutura que o sustenta, a autora traz um enredo clássico de amor triunfante. É em seu sentido mais literal e desenxabido que Jobim traz o romantismo prometido na capa de seu livro. Embora seja um termo atemporal e de expressivas possibilidades, na narrativa aparece limitado às relações amorosas estabelecidas entre um homem e uma mulher, em que esta, de forma muito mais invasiva, é tomada 
por suas sensações e sacrifícios, chegando até a desaparecer como indivíduos, como ocorre ao final da narrativa.

As mulheres representadas em Recados da lua (2001) têm suas vidas e narrativas pessoais erguidas em torno do amor. É dentro dos limites concedidos pelo amor-romântico que problemas, expectativas, ambições e as próprias personagens são construídas. E diante de um universo de possibilidades de recortes e tratamentos de temas e personagens, que perante a proposta da coleção ganham ainda mais relevo e suspeição, Helena Jobim privilegia em sua narrativa velhos recortes e situações e, na possibilidade de questioná-los e mostrar seus limites e contradições e, assim, romper estereótipos, opta por locomover-se no terreno seguro, doméstico e imaculado da literatura dita feminina.

\subsection{Amor e tempo}

Num mundo de relações cada vez mais líquidas e frágeis, como discorre Zygmunt Bauman (2004), falar de amor eterno é no mínimo ingênuo e antiquado. A fixidez negada em nome de um estado permanente de livre escolha, que parece descompassado ao compromisso, ou ainda nos termos de Bauman, ao parentesco ${ }^{16}$, faz as relações frágeis e cada vez mais efêmeras.

[...] homens e mulheres [...] desconfiados da condição de "estar ligado", em particular de estar ligado "permanentemente", para não dizer eternamente, pois temem que tal condição possa trazer encargos e tensões que eles não se consideram aptos nem dispostos a suportar, e que podem limitar severamente a liberdade de que necessitam - sim, seu palpite está certo - relacionar-se... (BAUMAN, 2004, p. 8).

Talvez por isso, ao abordar a relação entre o amor e o tempo, Ana Maria Machado tenha optado por falar não de um amor eterno, mas das eternidades encerradas no amor. É como um ciclo em constante movimento e renovação que o amor aparece representado em Para sempre (2001), que traz além da história de Nelson e Susana, a trajetória de mais dois casais, Zezé e Ewerton, Antônia e Daniel.

\footnotetext{
${ }^{16}$ Contraposto à ideia de afinidade, que seria eletiva, o parentesco, para Zygmunt Bauman, constituir-se-ia como irrevogável e indissolúvel. Torna-se parentesco seria, então, maior ambição das afinidades.
} 
Após um preâmbulo cheio de trechos de contos, crônicas e poesias, que discorrem sobre quando se daria aquele primeiro lampejo, que faria tudo começar e instauraria em nós a ambição de eternidade, a história de Nelson e Susana começa a ser contada. Apesar da latente promessa, já na primeira página do romance, de transposição de barreiras representada pelo descumprimento das divisões entre os gêneros literários, a desobediência mostra-se frustrada, já na própria escolha dos trechos e textos que abrem a narrativa: todos trazem o gesto da escolha como masculino, cabendo às mulheres o aguardo em ser escolhida.

Com muito mais frequência em poemas, novelas e romances do que em ensaios. $E$ isto não é um ensaio. A rigor, também não é uma novela. Mas numa época que vem abolindo cada vez mais as distinções entre os gêneros masculino e feminino, também é natural que as fronteiras entre os gêneros literários deixem de existir. Chamemos, portanto, de amor eterno (PS, p. 7). ${ }^{17}$

É pelo fim, selado pelo clássico "e foram felizes para sempre" que a narrativa efetivamente se inicia, "aí é que o tal amor eterno vai mesmo começar a ser testado, no dia-a-dia" (PS, p. 21) e o de Nelson e Susana foi. Passaram por crises, dívidas, seis gestações e, entre imprevistos e surpresas, boas e ruins, por quase trinta anos, eles sobreviveram. É um narrador/narradora intruso/intrusa, que abusa de recursos narrativos que são explicitados no próprio texto que a história é contada:

Uma espécie de mistura do flashback, retrospecto comumente usado nas narrativas, como um flash-forward, muito mais raro mas igualmente útil, uma forma de antecipação do que vai acontecer. Uma combinação de recursos que pode levar a um tipo de narrativa em costura, que dá um ponto em cada tecido temporal e os vai aproximando à medida que a agulha anda e a linha aperta.

Mas não há por que introduzir esses elementos no diálogo de Nelson, Ele já está muito debilitado e confuso com a medicação (PS, p. 94-95).

É pela perspectiva de Nelson, já velho, que temos esses trintas anos rememorados e analisados. De um jeito grosseiro e arrogante, ele, agora numa cama de hospital, conta, para uma pessoa não identificada e que diz escrever um livro, sobre o fim e os percalços de seu casamento com Susana. O fim começa com Tânia, ou ainda no que Tânia despertou no já

\footnotetext{
${ }^{17}$ As referências retiradas do romance Para sempre serão citadas pela sigla PS, seguida do número da página.
} 
entediado e tedioso Nelson. Amiga de uma de suas filhas, que já crescidas, não davam mais a atenção que o pai julgava merecer, Tânia, que sempre se interessava pelos conselhos e histórias de Nelson e ria "nas horas certas" (PS, p. 80) de suas piadas, restitui a ele o seu lugar de deferência.

Num capítulo longo, e distinto do resto, de pouquíssimas intromissões do narrador/ narradora, Nelson, guiado pelas perguntas de seu/sua entrevistador/entrevistadora e num misto de sentimentos que vão da estima ao desdém por Susana, lamenta-se, vangloria-se e justifica seus atos e escolhas. Num depoimento de aparência sincera e espontânea, ele não economiza palavras nem acusações e sempre cercado por argumentos que salvaguardam seu lugar de homem viril e provedor, constrói uma lógica hipócrita que desculpa suas atitudes e culpabiliza as circunstâncias.

Nós estávamos atraídos como homem e mulher. Uma coisa de pele e de corpo. Estava me fazendo muito bem, mostrando que eu estava vivo, inteiro, saudável, cheio de vida. Sabe lá o que é ficar trepando com a mesma mulher por quase trinta anos? Por maior que seja o carinho, o respeito, tem uma hora que não dá mais. A gente comparece, claro. Mas perde a graça. (PS, p. 85)

É também pela perspectiva de Nelson que Susana é construída na narrativa. Com um olhar raso e limitado às funções de mãe e esposa, é descrita como uma mulher de pouca complexidade, "que segredos uma mulher como a Susana podia ter? Ela não tinha vida própria, parou no tempo... Até mesmo um trabalho próprio ela nunca teve"(PS, p. 89). Embora tenha testemunhado os sacrifícios que Susana fez pela família, como abandonar sua promissora carreira como bióloga para cuidar dos filhos e da casa, Nelson não os considera como sacrifícios tangíveis e muito menos se enxerga como beneficiado das abnegações da ex-esposa, que para ele, "foi ficando em casa sossegada, de certo modo aposentada muito antes de mim"(PS, p. 90).

Ao enxergar Susana como alguém que dedicou sua vida aos outros, Nelson justifica a incapacidade dela em compreender sua necessidade de ter uma vida própria: "Uma vida anulada, voltada para os outros. Por isso é que ela não entendia que os outros podem não ser assim e ter necessidade de uma vida própria" (PS, p. 91). Mas quando Susana, depois de muitos perdões, promessas e tentativas fracassadas de reconquista, sentindo-se 
humilhada, coage o marido com a ameaça de expulsá-lo de casa e Nelson Ihe responde, do seu pedestal de provedor da família, que a casa era dele, era ele quem a sustentava, e como resposta a todas à essas humilhações, ela, numa atitude "egoísta", sai de casa, ele encara tal gesto como uma ofensa.

Porém, o único gesto inesperado (por Nelson) de Susana parece the custar a saúde. Se por muitos anos ela engoliu a traição do marido, depois de se separar, Susana parecia não conseguir digerir as escolhas do excompanheiro. Nessa mesma época, Susana chega a desenvolver uma série de problemas digestivos, interpretados, pelo/pela narrador/narradora e por sua filha, Antônia, como consequência direta do trauma de sua separação:

Agora engolia o choro, como se pedia das crianças antigamente. Mas que isso. Ao engolir as lágrimas, incorporava também o fato real: tivera que engolir Tânia e a nova vida de Nelson. Mas não conseguir digerir. Talvez por isso estivesse ultimamente tendo tantos problemas de saúde no aparelho digestivo, que a sucessão de exames, tratamentos e cirurgias ainda não conseguira vencer.(PS, p. 115)

Mais do que uma mulher que tem sua representação erguida em torno das possibilidades do amor, Susana aparece delimitada ao papel de mãe e esposa. Abnegada, ela nem sequer tem voz ativa na narrativa, e depois de os filhos e filhas crescidos e de um casamento esfacelado, a morte de Susana se dá física e metaforicamente.

Entre o fim de Nelson e Susana e o começo de Antônia e Daniel, somos apresentados à história de Zezé e Ewerton. Ela, que veio do interior de Minas Gerais para trabalhar como empregada doméstica na casa de Nelson e Susana, por causa de um curto-circuito, conhece Ewerton, eletricista, também migrante e solitário. Ao longo de três encontros, do conserto ao pagamento pelo serviço, eles se aproximam, descobrem similaridades e partilham memórias. É de forma breve que somos apresentados ao amor de Ewerton e Zezé, do namoro recatado aos preparativos do juntar os trapos, só temos acesso a poucos instantes de encantamento e a promessas de um futuro feliz e pleno.

Das observações trocadas entre os dois, a forma dúbia com que Ewerton percebe Zezé, ao identificar nela uma certa semelhança com a mãe 
e as irmãs, aparece como um prenúncio do que viria a acontecer nos anos seguintes:

Zezé fazia Ewerton se lembrar da mãe e das irmãs lá no vale do Itajaí. Não que fossem parecidas, impossível haver dois tipos de mulher tão diferentes - no colorido, no jeito de andar, no modo de falar. Mas tinha que reconhecer que todas elas lhe passavam a mesma impressão de força capaz de aguentar tudo, ao mesmo tempo misturada com uma delicadeza frágil de quem devia ser poupada de qualquer dificuldade maior. (PS, p. 51)

É Antônia, capítulos depois, quem nos conta o desfecho da história de Ewerton e Zezé. Ele, viciado em jogar cartas, perde tudo o que o casal tinha no carteado, começa a beber, fica doente e em pouco tempo morre, deixando Zezé com três filhos pequenos para criar. É um ciclo interrompido, mas não finito, o do amor de Ewerton e Zezé. Ela, que a tudo suportou em vida, parece, mesmo depois da morte do companheiro, nutrir um tipo de lealdade e devoção ao que sentia por ele. É um amor que a tudo sobrevive, ultrapassando inclusive a morte.

Como um ciclo que se renova, o amor renasce na narrativa com Antônia e Daniel. Com um começo um tanto diferente, "à primeira ouvida" eles se apaixonam, uma vez que Antônia se interessa pela voz de Daniel no rádio e ele pela voz dela num programa de televisão, e, assim como Nelson e Susana, vivem por muitos anos juntos. Porém se podemos elencar muitas diferenças principalmente entre Antônia e a mãe, no tocante aos relacionamentos, velhos dilemas e barreiras parecem repetir-se. Ela, professora de Língua Portuguesa, interessa-se por Daniel, um jornalista rebelde e irreverente, na época, ainda casado, o que faz Antônia, assombrada por uma antiga experiência e pela lembrança de Tânia na relação dos pais, lutar contra o sentimento "mais natural de sua vida"(PS, p. 73).

Descrita como a filha "mais sonhadora" (PS, p. 24) de Nelson e Susana, Antônia aparece na narrativa cercada pelo amor em todos os aspectos da sua vida. Se desde pequena sua maior ambição era viver uma relação como a de seus pais; adulta, ela, professora, faz do amor tema central de suas aulas, o que não deixa de ser mais uma forma de conectar os trechos literários inseridos na narrativa desde o preâmbulo. Sempre 
discutindo suas concepções e representações, Antônia concentra seus esforços em mostrar aos alunos e alunas como se dá toda construção cultural do amor e de como isso tem o poder de afetar nossas ambições e formas de vivenciá-lo. Mas refletir sobre o amor não faz de Antônia imune a ele ou às suas complicações.

Se muitas diferenças são traçadas ao longo da narrativa entre Antônia e a mãe, as motivações do declínio das relações permanecem num mesmo âmbito. Embora caracterizada como uma mulher experiente, independente, sexualmente liberada, que dispensa aliança, mas não a maternidade, Antônia revive o mesmo dilema de Susana. De uma forma menos ressentida, ela também passa pelos desgastes do tempo, que na narrativa, mais uma vez, parecem atingir unicamente o homem da relação, restando às mulheres lidar com tal conjuntura. Bem como Nelson, é Daniel o queixoso e insatisfeito com o casamento.

Diferente de Nelson, que na primeira pessoa expressa suas queixas e opiniões, Daniel tem as suas construídas pelo/pela narrador/narradora. Erguido a partir do pênis, descrito como um órgão com vontades próprias, o lamento do jornalista justifica-se na velha polarização das carências, em que o amor em nada se assimila ou interfere em suas necessidades mais prosaicas. O pênis aparece, assim, quase que como um terceiro personagem que se interpõe entre Antônia e Daniel. No trecho, cheio de imagens intencionalmente grosseiras, acentua-se a distinção no casal:

Com certeza não era a hora ideal para o pênis resolver dar essas demonstrações de independência. Mas deu, que diabo! Ficou cheio de vontades próprias. E se recusava a obedecer quando Daniel queria que ele se comportasse de acordo com seus sentimentos verdadeiros, sobre os quais não tinha dúvidas, para com a companheira de tantos anos. Não porque quisesse experimentar carne fresca aqui e ali - isso ele sempre quisera e nunca tinha atrapalhado coisa alguma. Mas de repente o desgraçado dera de ficar meio preguiçoso com Antônia, em sereno aconchego de ternura, quase vegetariano, e só se animar mesmo nas visitas ao açougue [...] (PS, p. 137).

Convencida da fatidicidade da traição nos relacionamentos duradouros, Antônia, que adiciona à sua biblioteca, antes cheia de "romances escritos por homens, que desde o século XIX celebravam o verdadeiro amor", livros de antropologia, escritos por mulheres, sobre o papel do adultério na 
manutenção do casamento, busca discutir com Daniel novas possibilidades de viver seu casamento. Porém, ainda que ela e o marido discutissem sobre a relação e sobre os fracassos que pareciam inerentes ao modelo tradicional, um tópico sempre permanecia omitido: o pênis. Mas se para Antônia a omissão do pênis, diante das suas "disfunções", dá-se pela vulnerabilidade potencial em sua discussão, para Daniel discutir a relação já não estava mais em questão.

É como um ciclo já completo e encerrado que Daniel vê sua relação com Antônia, o pênis era apenas um pequeno indício desse esgotamento do casamento. A perda do desejo pela esposa aparece como um disfarce que encoberta uma ânsia maior na vida de Daniel:

Não era algoz e prisioneiro de si mesmo, claro. Pelo contrário, estava era se dispondo a ir fundo na busca de uma liberdade que nunca procurara antes com tanta intensidade. Essa história de diminuição do tesão pela mulher era só um detalhe. Queria era fazer tudo o que tinha vontade. Ser livre. Controlar a própria vida (PS, p. 143).

Tal como Nelson, Daniel é tomado por uma necessidade de viver sua própria vida, ou ainda, uma nova vida. Enquanto no caso de Nelson, Tânia oferece esse novo frescor, com Daniel, é Sheila a responsável por fazê-lo sentir-se vivo. Sob as mesmas carências e desejos de sentir-se "forte, poderoso, dando as cartas" (PS, p. 145), a história se repete, e se na comparação entre Antônia e mãe somos capazes de observar algumas mudanças de comportamento, quando aproximamos Daniel de Nelson suas atitudes e pensamentos pouco se divergem. Sufocado pelas compreensões e ponderações da esposa, Daniel anseia ser como o pai e o avô, "queria poder gritar em sua casa" (PS, p. 146), busca pelo lugar e voz de autoridade, que só se torna possível com Sheila que, ao contrário de Antônia, o obedecia.

Mais do que falar sobre crises no casamento, Para sempre (2001) traz para o centro da narrativa uma crise masculina, são os homens os insatisfeitos, os únicos que parecem não saber lidar com os desgastes do tempo e das relações; as mulheres, por sua vez, parecem não ser atingidas por preocupações e esgotamentos próprios, apenas por problemas provindos da insatisfação de seus companheiros. 
Mesmo que a narrativa tente incitar problemáticas relevantes, principalmente por meio de Antônia, que é vista por Daniel como "uma mulher que queria ser igual a ele [...] cheia de discursos de independência" (PS, p. 145), ela fracassa e acaba por repetir velhos modelos de representação. As mulheres ainda têm o amor como o elemento central e realizador de suas vidas, mesmo que em Para sempre (2001) ele apareça como algo perecível e falho, sua preponderância na vida e escolhas delas é certeira. Prova disso é que, terminados os ciclos de Nelson e Susana e de Antônia e Daniel, é em Manuela, filha do último casal, que o amor renasce e um novo ciclo inicia-se, impulsionado por fabulações e expectativas que são por ela erguidas e já postas em lugar de destaque em sua vida.

É uma litografia do pintor Marc Chagall, conhecido por seus personagens flutuantes e atmosfera onírica, que ilustra a capa de Para sempre (2001). Influenciado pela tradição da pintura russa e pela iconografia judaica, Marc Chagall sempre quis fazer uma arte para o povo e em razão disso, aproveitando as estruturas já inicialmente desmontadas pelo Impressionismo, decompôs planos, modificou escalas, brincou com a lógica. Em Mounting the ebony horse he took her up (1949), figura 3, temos um casal em fuga, montados num cavalo, eles parecem flutuar enquanto se beijam, mas voar é só uma das inverossimilhanças representadas na obra de Chagall. De cor predominantemente azul, indicando que seria noite, há simultaneamente na gravura um sol, em um amarelo bastante vivo e contrastante com o tom frio do azul e uma pequena lua verde, que parece carregada por um segundo cavalo de rosto da mesma cor que a lua.

A quebra de padrões e perspectivas que desafiam nossos princípios de organização mais básicos, como o espaço e o tempo, que na obra de Marc Chagall obedecem a um critério puramente experiencial e emocional, parece ser um dos elementos de conexão entre a capa e a narrativa. Mas se em Para sempre (2001) ultrapassar barreiras como o tempo permanece uma ambição impossível de se concretizar, na obra de Chagall ele é maleável, dia e noite coexistem, não há barreiras nem limites. 


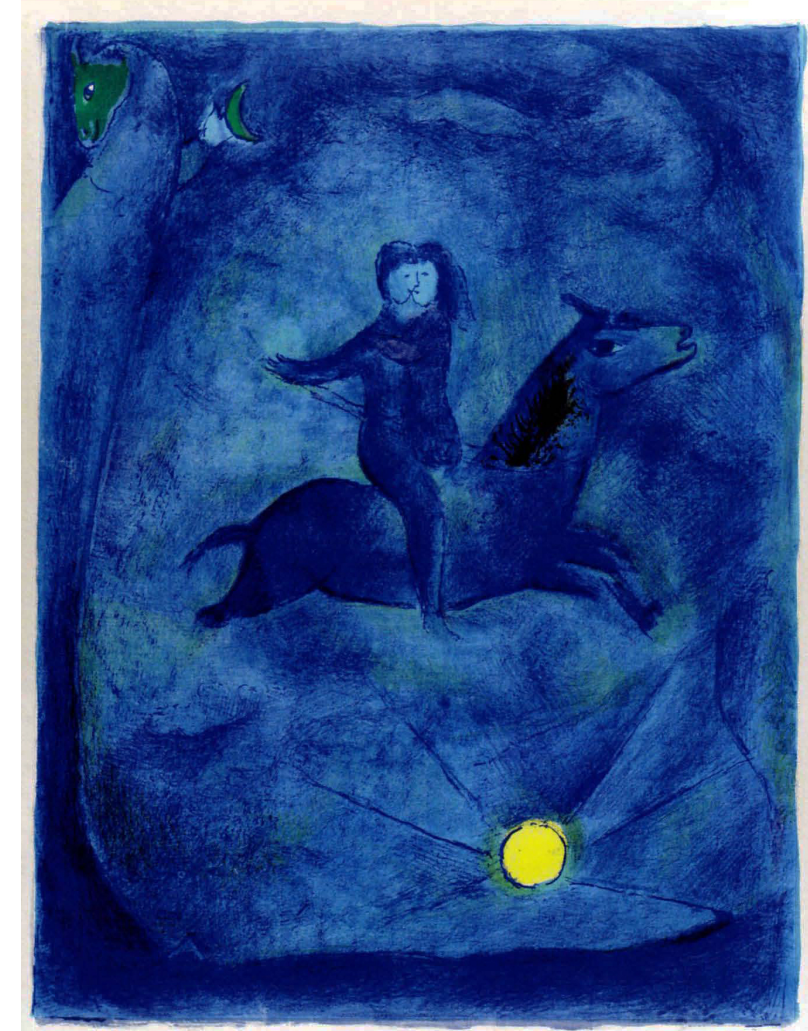

Figura 3 - Mounting the ebony horse he took her up (1949), de Marc Chagall

Figura 4 - Capa de Para sempre

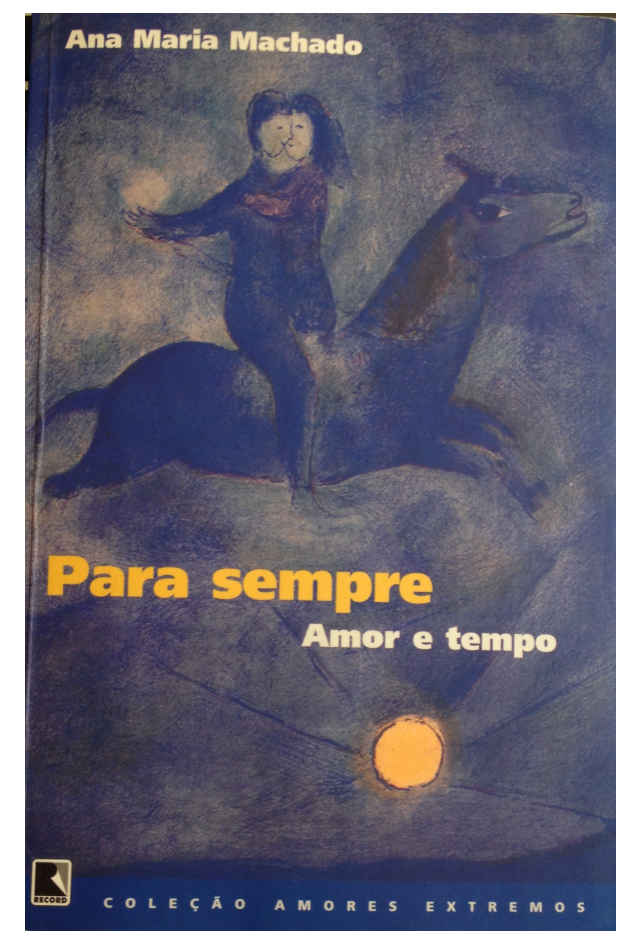

Desafiar tais barreiras e ansiar por uma dimensão fantástica, distante das leis do mundo físico, faz Marc Chagall ser considerado como um dos pintores mais românticos da Modernidade. Entretanto, se em Chagall encontramos um romantismo multiforme e transgressor em relação a suas escolhas estéticas o mesmo não ocorre em seu repertório. Mounting the ebony horse he took her up traz um casal, cujo homem toma as rédeas e escolhe o caminho a seguir enquanto a mulher, de costas, totalmente 
entregue, apenas se deixa levar, reiterando a velha proatividade restrita ao masculino.

Diante das infinitas possibilidades ofertadas pelas artes, literatura e pelo próprio universo das relações amorosas, ambas as obras mantêm-se presas a velhas e tradicionais representações e constroem personagens, ainda que flutuantes, no caso de Chagall, restritas a velhos papeis e dilemas.

\subsection{Amor e sedução}

Reiterando o argumento de que na literatura, as mulheres velhas, quando presentes, em sua maioria, têm suas histórias narradas por um outro, como comprova Susana Lima (2008) em sua tese de doutoramento sobre a representação da velhice feminina na literatura brasileira contemporânea em que delineia os espaços e construções possíveis das mulheres velhas, Estrela nua (2003), novela de Maria Adelaide Amaral, traz Hilde, uma velha cantora decadente por meio das palavras de Cadu, um jovem de dezoito anos que por ela se apaixona. É sob a perspectiva dele, um garoto inicialmente assustado e coagido pelas extravagâncias da cantora, que desde o início aparece como uma mulher desconcertante, de respostas rápidas e atitudes imprevisíveis, que a narrativa é desenvolvida. Em modo teatral, toda narrada por ele que conta com a presença explícita de um narratário: "você".

É como uma senhora muito diferente das outras senhoras que Hilde nos é apresentada. De cabelos tom de berinjela, solteira, sem filhos, com um histórico de muitos homens em sua vida e uma vida sexual ativa e sem culpa, Hilde contrapõe-se a muitas barreiras interpostas às mulheres velhas, e por essa mesma razão, num primeiro momento, não escapa do julgamento de velha louca e despudorada nem do sentimento de pena por não ter alguém que cuide dela e Ihe faça companhia.

O corpo, como indício evidente do processo de envelhecimento, ocupa espaço importante na narrativa, mas se o rosto de Hilde aparece marcado pela passagem dos anos, seu corpo permanece incólume aos desgastes do tempo: 
[...] cantava olhando para mim, os bicos dos seios empinados (eu já disse que ela tinha seios de garota?). Pois é: o corpo não tinha nada a ver com o cabelo e o rosto cheio de rugas. $\left(E N\right.$, p. 16) ${ }^{18}$

Bonito era o corpo da Júlia. O da Hilde era magnífico. Os seios, já falei dos seios dela? Durinhos, empinados. E a bunda também. E a pele, lisinha e macia, com cheiro dela. E eu ali morrendo de tesão. (EN, p. 47)

A imagem do corpo de Hilde aparece de forma recorrente na narrativa e funciona como fator preponderante no envolvimento de Cadu, que apesar de, também, se envolver por sua personalidade perturbadora, tem no corpo dela seu deslumbramento maior. Mas se, a princípio, trazer uma mulher velha para o centro de uma narrativa que se propõe falar de uma vertente sedutora do amor aparenta ser um gesto transgressor, pois a sedução, diretamente ligada a juventude e suas possibilidades reprodutivas, como bem aponta Michelle Perrot (2003), estaria restrita a corpos jovens e fecundos, nas escolhas da narrativa tal prognóstico não se mantém.

$\mathrm{Na}$ visão comum, a mulher no climatério já não é mulher, e sim uma velha, eventualmente dotada de mais poderes e liberdades, porém privada de fecundidade e, em consequência, de sedução. A própria palavra é uma injúria ou uma zombaria (PERROT, 2003, P. 16).

Inicialmente aturdido, Cadu, no processo de sedução, perpassa pelos estágios de repulsa, de vergonha, de medo e por fim de intrepidez diante de seu sentimento por Hilde. Se no começo, ele, um garoto cheio de certezas, quase arrogante, refere-se à Hilde como "velha" e faz pouco caso da forma como ela o olha, "O jeito como olhou pra mim! Uma menininha, uma adolescente. (Era constrangedor.)" (EN, p. 37), ao longo da narrativa e de seus encontros com a cantora, Cadu, já afetado por sua presença, nem mais consegue referir-se à ela como "a velha" e irrita-se profundamente quando algum dos colegas de banda assim o faz. Contudo, a influência que a presença de Hilde causa na vida de Cadu ultrapassa a forma de como ele a vê, alcança suas convicções e propósitos.

Conviver com Hilde, que por toda a narrativa provoca e desestabiliza Cadu, o desafiando a enxergá-la como mulher antes de velha, questionando

\footnotetext{
${ }^{18}$ As referências retiradas da novela Estrela nua serão citadas pela sigla EN, seguida do número da página.
} 
suas escolhas e expondo seus sentimentos mais recônditos, faz o garoto enxergar sua vida, relações e escolhas com novos olhos:

O pior de tudo (pior?) é que eu não estava mais aguentando a galera. Não tinha papo, compreende? [...]Eu não era mais brother de ninguém, muito menos daqueles caras. Mas de vez em quando sentia saudade deles e da época em que não enxergava os defeitos da galera. (EN, p. 83)

Reaproximar-se da avó, com o objetivo de tentar melhor compreender o universo de mulher velha habitado por Hilde, também é um gesto de Cadu impelido pela figura da cantora, porém mostra-se inútil. Em nada, além da idade, a estrela do bel-canto assemelhava-se à sua avó. A música, como o ponto de encontro entre os dois, aparece como um aspecto sobre o qual Cadu repensa. Se inicialmente, a banda de rock aparece como seu maior projeto de vida, ao final da narrativa, por influência e ajuda financeira de Hilde, Cadu viaja para Nova York para estudar composição.

É como uma espécie de mentora que Hilde aparece na vida de Cadu, sobretudo em relação ao sexo. Sexualmente liberada e com um largo histórico de aventuras amorosas, Hilde, que contrata serviços sexuais e insinua ter tido um caso com o próprio irmão, depois de um diálogo curto e direto, anui ao pedido de Cadu, "- Por que você não transa comigo? - Se você insiste" (EN, p.69). Enquanto o garoto, que diz "nunca ter ficado nervoso com uma mulher", aparece apavorado e, preocupado e concentrado na manutenção de sua ereção, que ameaçava desaparecer ao menor contato com o rosto de Hilde, "Está certo que o corpo era magnífico, mas o rosto tinha a idade dela. Era quase impossível transar olhando para ela" (EN, p. 72), Hilde mantém-se quieta, quase indiferente.

No malabarismo do esquivo do rosto velho de Hilde, Cadu, como quem fecha os olhos ao atirar, a agarra e a penetra; ela, passiva, quase apática, aceita e aguarda o gozo do parceiro. Se, a princípio, Cadu, por ter conseguido ejacular, considera seu desempenho satisfatório, ao receber de Hilde uma resposta negativa, inicialmente a diminui, "não devia ter insistido para trepar. Era só olhar para ela e para mim. Uma mulher que podia ser minha avó, não fazia diferença , que o corpo fosse jovem" (EN, p. 75) e, em seguida, chora feito criança. 
Considerando esse tipo de relação que Hilde mantém com Cadu, podemos enxergar Estrela nua (2003) como um exemplo de narrativa de formação. Em seu texto "Narrativas de formação contemporânea", Cíntia Schwantes (2007) ao discorrer sobre as novas formas de se construir esse tipo de gênero, recobra a fórmula descrita por Wilhelm Dilthey, que lista uma série de eventos que comporiam um romance de formação e boa parte deles encontramos em Estrela nua (2003). O conflito de gerações, uma viagem, a figura de um mentor, que na narrativa diferencia-se por ser uma mulher e não um homem mais velho, uma experiência amorosa fracassada e outra bem sucedida, antes de se apaixonar por Hilde, Cadu tem uma namorada, Júlia, a escolha profissional que irá torná-lo membro produtivo na sociedade e sobre qual Hilde tem influência direta sobre sua escolha. Ser uma narrativa rememorada também é um outro aspecto que reforça a teoria de uma narrativa de formação. De acordo com James Hardin (1993 apud SCHWANTES, 2007) é preciso, no romance de aprendizagem "uma alternância entre a ação e a reflexão" (SCHWANTES, 2007, p. 55), as experiências precisam ser mais que rememoradas, julgadas, avaliadas e sobretudo mesuradas.

Ainda que apareça como uma mulher sexualmente experiente e liberada, a educação sexual que Hilde aparenta fornecer a Cadu está fortemente baseada na velha divisão entre amor e sexo. Se antes, o repertório sexual de Cadu aparece restrito a trepadas e orifícios, após os ensinamentos de Hilde, que apresenta ao garoto um universo de possibilidades e minúcias que envolvem o ato sexual (quando há amor envolvido), construções e períodos da narrativa são abrandados:

Com o tempo, aprendi a subir minha mão pelas suas pernas e, com delicadeza, desvendar as dobras macias de seu sexo.

Também aprendi a saber quando ela queria ou não queria, quando estava pronta para me acolher. (EN, p. 78)

Ao final da narrativa, completamente envolvido por Hilde, Cadu anseia e planeja um futuro com ela, que, por sua vez, rechaça as expectativas do garoto e misteriosamente desaparece, deixando para ele o piano que the tinha prometido, um quadro, com seu retrato pintado e uma passagem para Nova York. É com uma atmosfera de mistério que se dá o desfecho da narrativa, que já desde o início nos oferece pequenos lampejos que nos 
fazem dúvidas da veracidade dos fatos que são contados: "Talvez nem fosse real. É isso aí. Eu estava começando a duvidar que alguém pudesse ser daquela maneira" (EN, p. 64)".

Essa vacilação, para Tzvetan Todorov (1992), é item definidor e sine qua non do elemento fantástico, uma vez que produz acontecimentos não passíveis de explicações por leis aplicáveis, "O fantástico é a hesitação experimentada por um ser que só conhece as leis naturais, face a um acontecimento aparentemente sobrenatural" (TODOROV, 1992, p.31). Dessa forma, trazer uma atmosfera fantástica para dentro de uma narrativa é colocar em dúvida a possibilidade de existência de seus arranjos e ações.

Como uma mulher de idade avançada, que o futuro já não aparece como a possibilidade mais atraente, insistir num tempo que não o presente parece ser escolha acertada. Mas se Hilde, pretensamente, aparece como agente de sua vida e escolhas, ao não fazer o papel de uma mulher ludibriada e enganada por um homem mais jovem, por não renunciar viver sua sexualidade, que fora das possibilidades reprodutivas, torna-se condenável entre tantos outros aspectos aqui elencados, sua história ainda é contada por outro. E se trazer uma mulher velha para dentro de uma narrativa, que tem como um possível escopo falar da sedução no amor possa ser interpretado como um tentativa positiva de inserção de novas possibilidades de representação dos gêneros, trazer aspectos como o corpo e o lugar de fala limitados a perspectivas tradicionais e recorrentes retira de tal gesto sua potência .

Parte do quadro do visceral pintor expressionista Egon Schiele, "A contemplada no sonho" (1911), figura 5, ilustra a capa de Estrela nua (2003). $\mathrm{Na}$ íntegra, a obra traz uma mulher, nua, estendida, que escancara frontalmente o interior de sua vulva. De cores predominantemente pasteis, como típico da obra de Schiele, a composição traz poucas intervenções de tons escuros, restritos ao tecido que cobre o rosto da mulher e a seus cabelos e pelos pubianos, e de tons mais quentes, que concentram-se nas zonas erógenas e sensíveis do corpo, como vagina, lábios e bicos dos seios. De olhos fechados, a mulher não nos encara, mas aparenta expor-se a um voyer, não como alguém que se toca, se masturba, ação frequente nos desenhos de Schiele, mas apenas exibe seu sexo. 


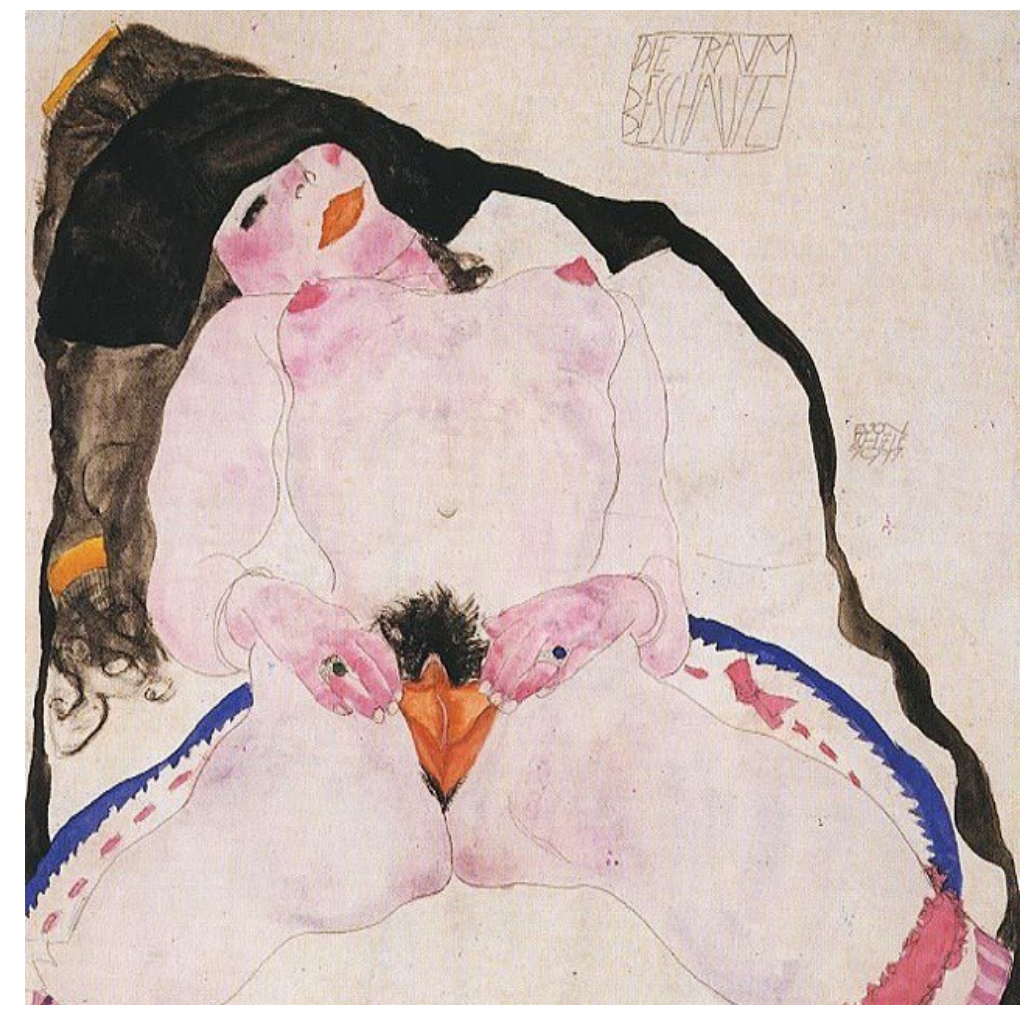

Figura 5 - A contemplada no sonho (1911), de Egon Schiele

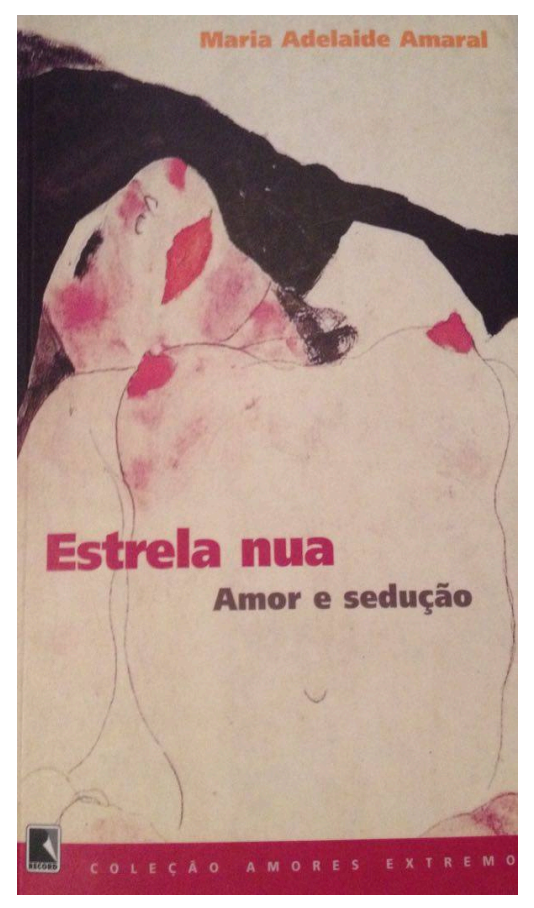

Figura 6 - Capa de Estrela nua

É uma sexualidade crua, corpórea e genitalizada a presente na obra de Egon Schiele, que com traços tortuosos constrói corpos angulosos, distorcidos, que beiram à abjeção. Mas se em grande parte o impacto dessa 
obra em específico concentra-se no tratamento explícito do corpo feminino, o recorte escolhido na diagramação da capa, como indica a Figura 6, opta por excluir sua parte mais exposta e foca nos aspectos sexuais mais sutis e já socialmente considerados menos ofensivos, como os seios e o olhar. Grotescos em sua maioria, os corpos na obra de Schiele não me parecem adequados para ilustrar uma narrativa que isola o corpo das ações do envelhecimento, e talvez, por essa razão tenha sido preciso, assim como na narrativa, fragmentar partes e composição dos corpos e quadros.

\subsection{Amor e desejo}

É sobre um terreno movediço, cheio de incertezas que Heloísa Seixas constrói sua narrativa. No embaralhamento de tempos, dimensões e sentidos, Através do vidro (2001) traz a história, ou ainda divagações, de uma mulher que, incitada, a priori, por um telefonema, reaviva uma velha paixão do passado. Do desligar do telefone em diante, tudo na narrativa enche-se de vacilação, por meio de cenas e sensações que se repetem, como em um simples tocar no tecido de um assento e num recostar-se sobre o vidro de uma janela, somos transportados/transportadas entre lugares e lembranças.

Uma mulher, casada, de meia idade, escritora, e de alguma notoriedade dado que é localizada por seu antigo namorado por uma entrevista em um jornal, são as informações que temos da protagonista de Através do vidro (2001), que não é nomeada. Escrito em terceira pessoa e narrado por um/uma narrador/narradora onisciente, que ao fim da narrativa, numa frase breve, identifica-se também como escritor/ escritora, "Nós, escritores, somos assim" (ADV, p. 109) ${ }^{19}$, apesar de única e sucinta, a declaração do narrador/escritor ou da narradora/escritora revela uma escolha bastante significativa de Heloísa Seixas, que opta por "desaparecer" no masculino plural.

O romance de Seixas abusa de descrições que, em vez de nos situar, confundem evidências e constantemente nos jogam numa espécie de limiar

\footnotetext{
${ }^{19}$ As referências retiradas do romance Através do vidro serão citadas pela sigla ADV, seguida do número da página.
} 
entre o sonho e realidade. É com uma riqueza de detalhes, que chegam a surpreender inclusive à própria personagem, que as cenas são narradas:

Não compreendia como podia fabricar, dentro de si própria, uma trama tão precisa, de contornos tão nítidos, um mundo com espessura e profundidade, sabor, cheiros e cor, um mundo cuja textura podia sentir agora mesmo, nesse exato segundo, contra a pala da mão, sob os sensores dos dedos com a mesma exatidão com que sentiria a trama aveludada de um assento. (ADV, p. 55)

Após um primeiro capítulo de exposição das sensações e dos desejos despertados pelo telefonema e pela proposta que recebe de seu antigo amor de adolescência, que a propõe um novo encontro, a protagonista cerca-se de argumentos que possam legitimar sua vontade e ansiedade em vê-lo. $O$ peso do tempo funciona como um dos elementos resolutivos desse desejo. Do seu lugar de mulher de meia idade, que não se vê com um futuro cheio de possibilidades e cujo corpo dá sinais irreversíveis de envelhecimento, a personagem depara-se com uma última chance de viver tal paixão:

Não tinha porque se enganar. Sentia a passagem do tempo na pele, nos pés, no brilho do olhar quando se encarava no espelho. Já não sangrava com a mesma regularidade, toda ela começava a murchar. Cremes, líquidos, porções. Agulhadas, massagens, choques, exercícios. A luta para tentar deter a passagem do tempo - inútil, porém. Seu corpo lhe dava adeus, todos os dias.

Como, então, recusar?

Era sua última chance. (ADV, p. 15)

A crença nesse estágio de decrepitude do corpo, na narrativa, extremamente ligado à menopausa reforça muito uma ideia, aqui já mencionada na análise de Estrela nua (2003), de Maria Adelaide Amaral, de que o exercício pleno e saudável da sexualidade estaria diretamente relacionado e limitado à fertilidade. Em seu texto "Velha? Eu?", Tania Navarro-Swain (2003) ao discorrer sobre a velhice como uma categoria social que nos polariza e hierarquiza, compara a construção da menopausa como um recriação de um corpo doente, tal como a histeria, e denuncia sua articulação como mais um mecanismo de assujeitamento dos nossos corpos, com o qual não concorda:

[...] a menopausa é, para as mulheres, um rito de passagem, mas uma passagem para o reino das sombras, pois ao perder a fecundidade, base da feminilidade, o corpo-em-mulher se torna "inútil"; a sexualidade sofre um deslocamento, entre liberação, culpabilidade, rejeição (NAVARRO-SWAIN, 2003, s/p). 
Ante a derradeira chance de viver tal encontro, assim como ocorre no último dia que eles, ainda adolescentes, passam juntos, a protagonista vê-se obrigada a tomar atitudes ousadas. Se quando jovens, a iminência do adeus rompe amarras e deixa escapar um desejo até então reprimido, e eles, às escondidas, se encontram e ele a masturba; agora, passados trinta anos, ainda sob a lembrança do toque e do desejo de viver de forma plena e conclusa tal intercurso, a personagem principal de Através do vidro (2001) vê-se diante do mesmo sentimento e sente-se obrigada a tomar atitude de mesma magnitude:

Não fizeram amor, mas naquelas loucas batalhas ele conseguira um
feito: dera-lhe prazer. Com ele, ela vivera a suprema vertigem, pela
primeira vez. E embora ao se separarem seu corpo continuasse virgem,
a verdade é que ele fizera dela uma mulher. Fora seu primeiro homem.
Guardava dentro de si a memória do toque preciso, mãos, braço, boca,
percorrendo-a sem pressa, num encaixe perfeito. [...] Precisava ir. Em
nome da menina que tinha sido um dia, em nome do corpo rijo em cujas
veias correra um sangue quente e limpo (ADV, p. 16).

Como uma mulher casada e, ao que parece, feliz e realizada em seu casamento, o desejo do reencontro vem acompanhado de um sentimento de culpa que, na perspectiva da personagem, parece independer de sua real concretização. Influenciada talvez pelo mar que observa, nas primeiras páginas, pela varanda de seu apartamento, antes mesmo de o telefone tocar, o primeiro lugar que a protagonista imagina seu encontro é num barco em alto mar, e é como um castigo que ela interpreta a tormenta por qual passam:

Por que, então, encarar como uma traição, passível de castigo? Trair. Palavra detestável. O que significava, afinal? Onde há mais traição no ato de beijar outra pessoa ou na mais louca, detalhada, desvairada fantasia? Por que, então, nem assim conseguia realizar seu sonho? Por que, então, a imaginação permeada de pesadelos? Por que o mar? 0 mar engolindo tudo, o mar que era desejo, o desconhecido. (ADV, p. 56)

Como uma fantasia erótica, a retomada da relação, para a protagonista, na narrativa, não parece ter como objetivo uma vivência romântica longeva, mas antes, mostra-se como um desejo de consumação. Mesmo que em sua primeira relação sexual, ela tenha alcançado o gozo, a narrativa, ainda pautada na ideia de perda da virgindade ou de sexo 
"consumado" como uma incumbência da penetração pelo pênis, constrói a cena como uma falta, uma dívida, reforçando o protagonismo do homem na relação: no que se refere à virgindade, como aponta Giddens (1993), dispõe mais que um papel principal, uma participação positiva e engrandecedora, contrário às mulheres que ainda hoje "perdem" a virgindade:

A "perda da virgindade"para um rapaz, hoje em dia, assim como desde os tempos imemoriais, continua sendo uma expressão imprópria: para os rapazes, a primeira experiência sexual é uma adição, um ganho. [...]. Para as garotas, a virgindade é ainda considerada como uma entrega (GIDDENS, 1993, p. 61).

A narrativa desenvolve-se, assim, na busca por um remate da relação, que só parece ser possível por meio de um sexo que se desenvolva com penetração peniana, como ocorre em cada desfecho de suas divagações:

Com a mulher subjugada, o homem se colocou sobre ela, preparando o ataque.

E, no momento em que a penetrou, de um só golpe, um trovão sacudiu os céus. Na vertigem do gozo, ela ainda sentiu os grossos pingos que escorriam pelo rosto [...] (ADV, p. 48).

Foi assim, ainda, sem nem por um segundo desviar o olhar, que tomou posição para nela cravar-se. E quando o fez, ambos sentiram o instante perdidos nos olhos um do outro (ADV, p. 81).

A forma como os encontros sexuais são descritos também repisam velhos estereótipos, insistem na metáfora do corpo feminino como um território a ser desbravado e conquistado e na figura de um homem ativo e controlador e uma mulher passiva e delicada e ainda que em um trecho do livro fale de uma espécie de androginia no ato sexual, tal descrição permanece presa a termos e concepções sexistas, em que o homem e a mulher para se comportarem fora desses padrões de comportamento precisam estar sob um domínio de outra ordem:

O homem era um sábio. Ela não se enganara. Singrava seu corpo a um só tempo com delicadeza e força, lábios e mãos agindo como se pertencessem a um ser andrógino, homem e mulher. As mãos viris, de dedos rudes e pala áspera, deslizavam como vigor sobre a pele, como só um homem é capaz de ousar, mas, nesse deslizar, desvendam segredos que apenas às mulheres é dado conhecer (ADV, p. 40).

A reincidência de cenas, sensações e frases ajudam a construir a atmosfera onírica que envolve Através do vidro (2001). Textualmente 
destacadas, característica bastante presente nas obras de Heloísa Seixas ${ }^{20}$, pelo intervalo de um duplo espaço entre os parágrafos e o uso de letras em caixa alta nos primeiros períodos dos parágrafos, tais iterações, como num fluxo de sonho e pensamento, são repetidamente trazidas na narrativa nos deslocando entre lugares e dimensões:

A MULHER OLHOU PARA OS PRÓPRIOS PÉS. Viu quando eles tocaram o chão do barco, que oscilou um pouco mas em seguida acalmou-se. (ADV, p. 25)

A MULHER OLHOU PARA OS PRÓPRIOS PÉS. Viu quando eles desapareceram na água escura. $E$, num segundo, a areia fina se transmutou em lodo. (ADV, p. 65)

A MULHER OLHOU PARA OS PRÓPRIOS PÉS. Viu quando eles tocaram o chão de terra batida do pátio, no instante exato em que saltou do carro. (ADT, p. 81)

Frágeis, as fronteiras entre realidade e imaginação são fácil e brevemente ultrapassadas na narrativa. $O$ fato de a protagonista ser escritora é utilizado como argumento de sua destreza no deslocamento entre esses planos:

A mulher sabia muito bem. Conhecia os perigos de oscilar entre dois mundos - pode-se resvalar e nunca mais voltar. Nós, escritores, somos assim. Sofremos de uma espécie de esquizofrenia. Vivemos possuídos, mergulhados em devaneios que nos arrastam e envolvem até não sabermos mais onde estão as divisas, quem somos e onde pisamos. (ADV, p. 109)

A dimensão do sonho sendo elástica e aberta a mil possibilidades, literariamente, mostra-se bastante atrativa e frutífera, porém, o que se escreve numa dimensão distante do real parece perder força de efeito no estabelecimento e disseminação de significações de suas representações. Em seu texto "Deslocar-se para recolocar-se", Virgínia Leal (2011), ao analisar a construção das relações homoeróticas entre mulheres representadas nas obras de cinco escritoras, observa alguns aspectos que mostram-se recorrentes na composição dessas obras. Por colocarem em cena um tema que desafia uma série de preceitos sobre o gênero e o exercício de sua sexualidade, em todas as cinco autoras analisadas por Leal, sempre há a ocorrência de algum tipo de deslocamento para um outro

\footnotetext{
${ }^{20}$ Em seu artigo sobre a análise de alguns contos de Heloísa Seixas, Luiza Vilma Pires Vale chega a salientar o frequente uso de recursos gráficos. Ver VALE, "O duplo em 'pantáculo'e 'Santa Rússia", contos de Heloísa Seixas.
} 
lugar, seja ele concreto ou imaginário, que abrem um espaço possível para a realização dessas relações, que parecem não caber no círculo diário das personagens. Dessa mesma forma, as viagens e divagações da personagem de Através do vidro (2001) constroem um espaço possível e permitido para suas fantasias eróticas. E trazer uma narrativa, construída sob um potencial viés erótico, e optar por enclausurá-lo num mundo de fantasia, enfraquece seu uso e suas possibilidades emancipatórias. E mesmo as fantasias eróticas descritas no livro são tradicionais.
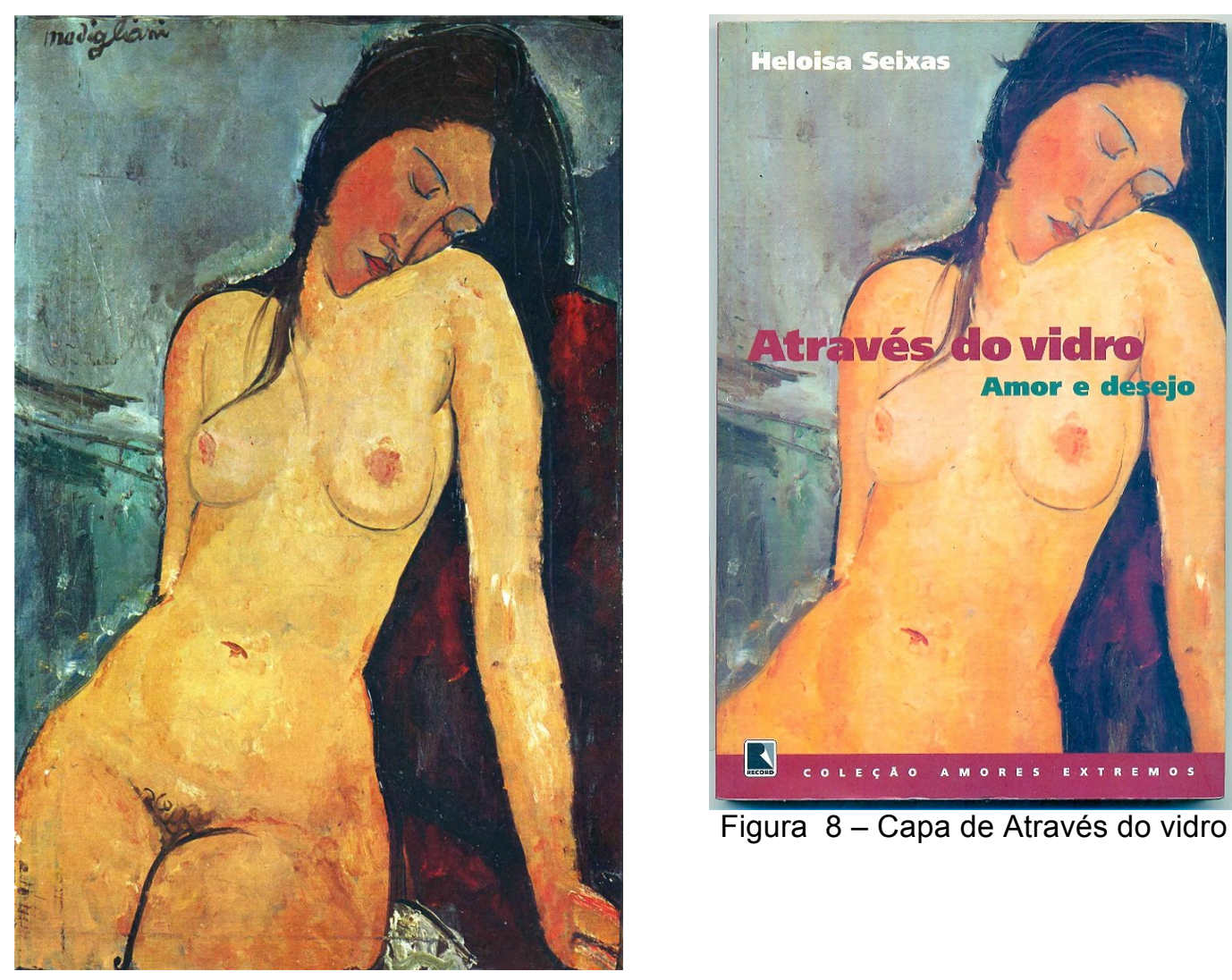

Figura 8 - Capa de Através do vidro

Figura 7 - Nu sentado (1916), de Amedeo Modigliani

Uma mulher voltada para si, fechada em seus pensamentos, ilustra a capa de Através do vidro (2001). Obra de Amedeo Modigliani, "Nu sentado" (1916) (fig. 7) traz tema e traços típicos do pintor: nudez e corpos longilíneos. Com linhas definidas, traços angulosos e tons cálidos, que em contraste com o fundo, dão forma ao corpo e delimitam planos. Modigliani, muito influenciado pelo cubismo, constrói uma composição assimétrica, mas mantém-se ainda claramente preso a modelos tradicionais, como sugere não 
só sua temática, como também a disposição e o tratamento do corpo feminino, ainda voluptuoso e voyeurístico.

$\mathrm{O}$ rosto anguloso, de traços afilados e de tom mais quente e escuro que o resto do corpo, faz do torso mais iluminado e evidente. Porém, se o corpo aparece exposto e vulnerável, rosto e pensamentos, oblíquos, não nos parecem tão acessíveis. Tal como a protagonista de Através do vidro (2001), a mulher representada no quadro de Modigliani parece alheia ao que the é exterior, reclusa a seus pensamentos, e ainda que nós, por meio de um narrador/narradora consigamos acessar reflexões e divagações mais íntimas da personagem do romance, as dúvidas que são interpostas ao longo da narrativa nos coloca igualmente como expectadores/ expectadoras e elucubradores/ elucubradoras de seus pensamentos.

Tal como ocorre na análise anterior, em que há também um corte significativo da diagramação da capa, que traz um recorte e não a obra em sua integralidade, em Através do vidro (2001), há uma supressão da parte inferior do quadro eliminando, como podemos ver na figura de número 8. Num gesto de "higienização" da obra, os pelos pubianos que, há anos atrás, fez a obra de Amedeo Modigliani ser considerada obscena e sua exposição em Paris, em 1917, poucas horas depois de aberta, ser fechada, são eliminados; o foco, assim como em Recados da lua (2001), limitado aos elementos sexuais socialmente considerados não-agressivos.

Dos muitos elementos que conectam as quatro narrativas até aqui analisadas, ser construída a partir de perspectivas tradicionais que insistem em concepções de amor ainda extremamente arraigadas a sua vertente romântica e limitadas a determinados papeis de gênero é o que uniu este primeiro bloco de análise. Na parte que se segue, serão analisadas aquelas que de alguma forma prometem desafiar, mas não necessariamente cumprem, tais lógicas. 


\section{Capítulo III}

\subsection{Amor e pecado}

Das sete obras que compõem a coleção Amores Extremos, $O$ pintor que escrevia (2003), de Letícia Wierzchowski, é a que traz o amor sob um viés mais inquietante. Um incesto entre irmãos orquestrado pela própria mãe de um deles é o que movimenta a narrativa que, diante de tal temática, é construída numa atmosfera de segredo e mistério. "Um mulher louca, uma mulher bela e um pintor suicida" (OPQE, p. 39) ${ }^{21}$. É como o marchand, Augusto Seara, que vinte anos após a morte do pintor, Marco Belucci, resgata e resume o que se passou entre os três. Ele, pintor italiano, vem para o Brasil a convite de Antonia Maestro, mãe de Amapola, sob a promessa de poder, aqui, viver com ela, que nada sabe sobre seu parentesco com Marco.

Após um breve capítulo que retoma os últimos dias de vida de Belucci, revivemos e reavivamos com Augusto Seara, um marchand que a pedido de Amapola, viaja até a antiga casa, onde ela e Marco viveram, para catalogar e vender todas as suas obras, os segredos que cercavam a casa e as obras de Marco Belucci. É a partir dos quadros dele que aos poucos descobrimos as razões da angústias e tormentos que desde as primeiras páginas se fazem presentes; e se traços, cores, olhos vazados nos dão a dimensão do sofrimento vivido pelo pintor, mais tarde, descobertas as confissões secretamente escritas no verso de cada quadro, comprovam a causa e a dimensão de seu remorso.

Pintou cada um daqueles retratos, o horror e a paixão estão ali. Todos os medos, os segredos do seu passado, o pecado por ele cometido, o mais terrível pecado, o mais perene, está tudo naquelas telas para quem tiver os olhos de ver, os verdadeiros olhos que sabem penetrar nos signos sob o pano. Sua vida codificada em cores, traços, nuances. O seu diário, o seu tarô (OPQE, p. 13-14).

Cheia de construções e referências plásticas, a narrativa transpõe para a escrita, para o trabalho da linguagem a temática artística presente em seu enredo. Cores e texturas ambientam cenas e sensações, sempre

\footnotetext{
${ }^{21}$ As referências retiradas do romance $O$ pintor que escrevia serão citadas pela sigla OPQE, seguida do número de página.
} 
impregnadas pelo peso de horror e pecado que envolvem o tema do incesto. A casa, como um limite protetor e permissivo daquela relação, aparece como primeiro indício da atmosfera de segredo que ocupa a narrativa: "Aquela casa tinha tristeza incrustada em suas paredes, tristeza era o que cimentava os tijolos que a erguiam" (OPQE, p. 33).

Ainda que, majoritariamente, narrada em terceira pessoa, por um narrador onisciente, é sobretudo pela perspectiva atormentada de Belucci que temos a história revelada. São principalmente seus quadros e anotações, descobertos por Augusto Seara, que aos poucos constroem a trama e suas personagens. No acaso do desencaixotamento dos quadros, acompanhamos toda trajetória do amor de Marco e Amapola, o primeiro encontro, promovido por Antonia, a partida para o Brasil, o aborto sofrido por Amapola e finalmente a revelação do segredo que por décadas afligiu Belucci e, por consequência, sua pintura.

Antônia Maestro, senhora de alta classe, mãe de Amapola, é pintada e descrita por Marco como uma mulher extremamente fria e temerosa. É de forma demoníaca que Belucci representa Antônia: Fantasmagoria ${ }^{22}$ é o título que dá ao quadro que traz o retrato dela, num fundo cinzento e denso, onde ela como uma criatura pictórica, um demônio flutua. Responsável pelo enlace do pintor com sua filha, em razão de um plano mórbido e inescrupuloso de criar um ser, de beleza suprema, um neto/neta, fruto de uma combinação dos traços perfeitos dele e de Amapola, e também por vingança ao marido que a traía, ela os manipula, e quando, não mais suportando lidar com o "pecado" que cometera, Marco comete suicídio, Antônia encara tal gesto como uma fraqueza do pintor e uma ofensa a sua pessoa: "Marco Belucci era um fraco, um fraco. Maldito dia em que o escolhera para Amapola. Maldito destino, maldita ambição. Marco Belucci havia morrido sob seu nariz, como uma afronta" (OPQE, p. 19).

Em meio aos planos da mãe e a culpa de Marco está Amapola, que apesar de poupada do conhecimento do incesto, convive com uma espécie de culpa por não ter proporcionado a Marco razões e vontade para continuar

\footnotetext{
${ }^{22}$ De mesmo título, Fantasmagoria (1987), Iberê Camargo possui um quadro de estética e cores bastante similares com as descritas na narrativa que cheia de referências plásticas nos faz cogitar uma possível relação e referência entre as obras.
} 
a viver ao seu lado. Vista como uma mulher bela, simultaneamente frágil e resistente, tal como sugere seu nome, "nome de uma flor de cáctus. [...] capaz de viver em lugares secos como os desertos" (OPQE, p. 24), Amapola, aparece nos quadros de Belucci de forma bastante angustiante, com olhos sem pupilas ou tapados pelas mãos, Amapola é sempre impedida de enxergar por escolha própria ou não, nunca encara o que está a sua volta ou seu espectador:

Amapola azul. Óleo sobre tela, 1957. 130 x 180. Uma mulher nua e azul, talvez feita de gelo. Erótica e triste, a nossa mulher em cobalto. Seus olhos não têm pupilas, e é como se ela não pudesse ver. Pintura expressionista de uma grande intensidade cromática, que passa pelos vermelhos e vai até o branco (OPQE, p. 60).

Tem mais ou menos $60 \times 100$. Óleo sobre tela. A tela exibia Amapola com as mãos sobre o rosto, os seios nus. Havia angústia naquele gesto pictórico. Os dedos longos cobriam seus olhos. Os seios eram jovens e frescos, de mamilos rosados. Uma suave luminosidade banhava a tela de maneira homogênea e perfeita, dilacerando cruelmente a angústia que parecia vir daquela mulher talvez desesperada de amor (OPQE, $p$. $68)$.

Nas descrições desses quadros há a representação de uma cegueira pretendida. Aos olhos de Marco, Amapola jamais suportaria tamanho infortúnio. Porém, impedi-la de ver configura-se, para além de uma medida "protetiva", envolve o não-poder de escolha dela. Incesto e olhos extirpados são aspectos emblemáticos de uma das principais tragédias da literatura, Édipo Rei, de Sófocles ${ }^{23}$. Utilizada por Aristóteles na definição do gênero trágico, ela apresenta uma série de elementos típicos citados em sua Poética. Elementos que são também encontrados em $O$ pintor que escrevia (2003), apesar de contrária à tragédia a narrativa apresentar um incesto tramado e a cegueira apresentar-se de forma auto-infligida pelo incestuoso. Para além da temática, as aproximações dão-se nos próprios elementos da narrativa, como o erro involuntário que transgride alguma lei (também entendido como pecado) se fazem presentes. Para Aristóteles, o elemento trágico é acentuado quando esse erro acontece entre pessoas que se amam, como Antônia e Amapola, e Amapola e Marco.

\footnotetext{
${ }^{23}$ Essa ideia foi sugerida em conversas com Virgínia Maria Vasconcelos Leal, ao recordar que Sigmund Freud se baseou na tragédia grega na sua formulação do Complexo de Édipo. Ver GIMENES. Em sua dissertação ela aproxima Édipo Rei à obra, também contemporânea, Lavoura Arcaica, de Raduan Nassar.
} 
O próprio personagem Marco configura-se com um típico herói trágico, aparece como uma boa pessoa que tem sua trajetória marcada pelo infortúnio de amar e casar com a própria irmã, razão pela qual comete suicídio, que aparece como uma tentativa de remissão de seu pecado. 0 erro seguido de um castigo é um desses elementos característicos da tragédia presentes na narrativa. A catarse, para Aristóteles, seria responsável pela depuração dos sentimentos de piedade e temor (sobretudo em casos de incesto) é alcançada pela figura do marchand, Augusto Seara, que encontra nas obras de Belucci a possibilidade de sublimação daquele amor: "Assim, cumpriria a sua tarefa: transformaria aquele amor de pecado numa espécie de lenda, imune ao tempo e purificada pelos anos. E eterna, talvez." (OPQE, p 142).

Conjuntamente ao incesto, a guerra traz ao amor de Marco e Amapola dimensão e extremidades particulares. Como judeu, na Itália em plena Segunda Guerra Mundial, Marco vivencia as ameaças da guerra e por elas parece ter seu amor potencializado. Impulsionado pelo risco de morte e pela possibilidade de encontrar longe dali um reduto onde ele e Amapola pudessem viver, incólumes e salvaguardados, Marco vem para o Brasil com Antônia e a filha. Porém, apesar da distância, do isolamento e do total desconhecimento dos outros do "estado de pecado" dos dois, o pintor passa os últimos anos de sua vida atormentado por um amor que parece ganhar ainda mais força na sua devastação.

Um tema tabu, o incesto carrega em si uma série de preceitos e problemáticas que são frequentemente chacoalhados quando o colocamos em discussão. De uma perspectiva psicanalítica ou antropológica ${ }^{24}$, não parece haver abordagem que dê conta de tal assunto em termos absolutos. O antropólogo Claude Levi-Stauss, ao pensar tudo que diz respeito à ordem da natureza como universal e como contingente, o que pertence à cultura, depara-se com o incesto numa situação ambígua, bipartido em caracteres sociais e biológicos.

Como um interdito sexual, o incesto é peça fundamental na instauração e manutenção do modelo nuclear de família, seu caráter de

${ }^{24}$ Ver PONTES,O tabu do incesto e os olhares de Freud e Levi-Strauss. 
construto ético-moral vem milenarmente garantindo expansão e continuação de famílias; e trazer para o centro de uma narrativa, que tem o amor como seu tema primário, é colocar em evidência uma das formas mais condenáveis de se vivê-lo, é fragilizar um script de organização e comportamentos das relações amorosas. Porém, recheada de culpa e autoflagelações, a narrativa, restrita à conotação pecaminosa, termina numa tentativa de purificação do amor de Marco e Amapola que, diante da impossibilidade de uma realização plena de seu o amor, o têm purificado e eternizado nas obras de Belucci, como bem afirma Augusto Seara no término do livro, em trecho já citado anteriormente: " transformaria aquele amor de pecado numa espécie de lenda, imune ao tempo e purificada pelos anos. E eterna, talvez (OPQE, p. 142)".

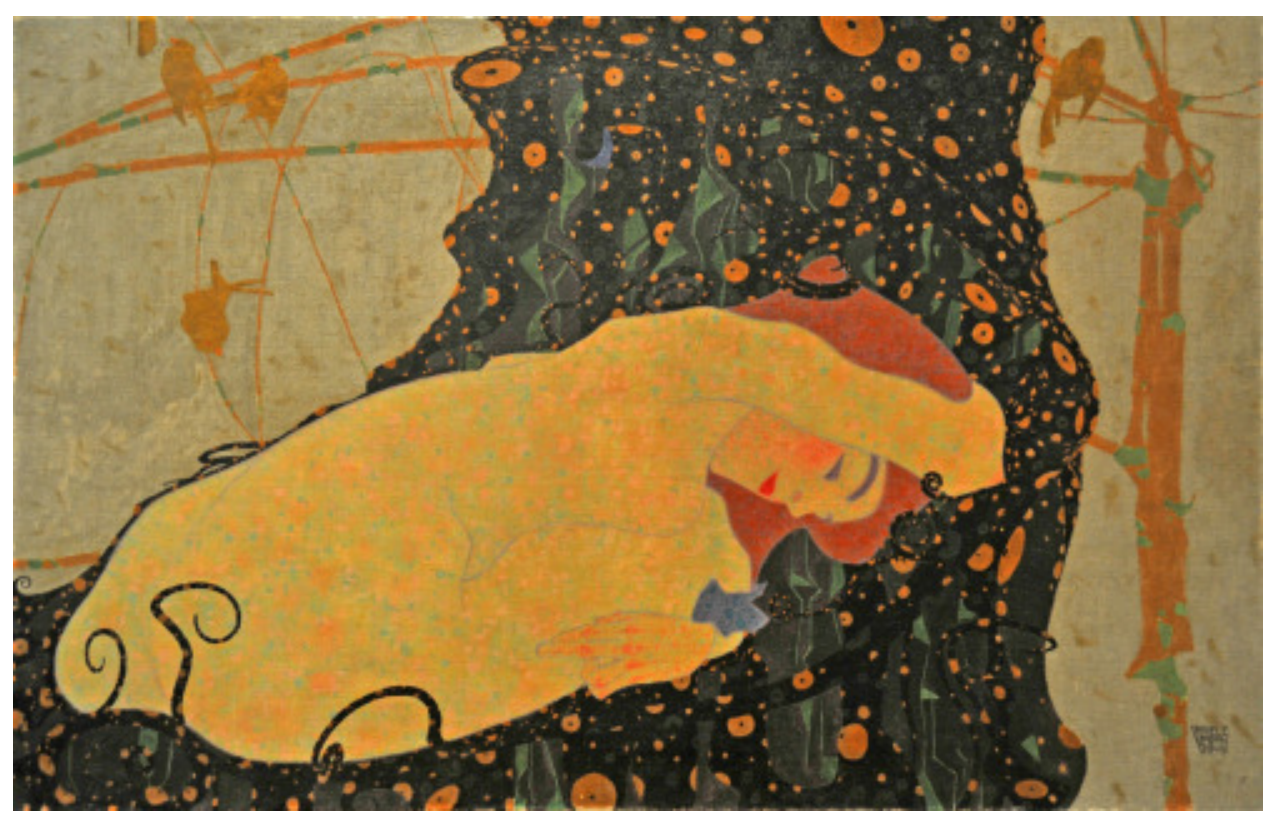

Figura 9 - Danae (1909), de Egon Schiele

Uma mulher debruçada sobre si mesma, envolta por uma mancha negra repleta de pontos em tom alaranjado, ilustra a capa de $O$ pintor que escrevia (2003), que traz pintura Danae, de Egon Schiele. Cores e disposições enchem-se de significado quando, avisados pelo título, identificamos a figura de Danae, na mitologia grega, uma princesa virgem, que enclausurada numa torre, engravida de Zeus que transmuta-se numa chuva de ouro e ao cair sobre seu colo, a engravida. Tema de muitas 
pinturas dos anos 1900, Danae foi pintado por muitos pintores, como Ticiano (Figura 2) e Gustav Klimt (Figura 3), não por acaso, professor de Egon Schiele.

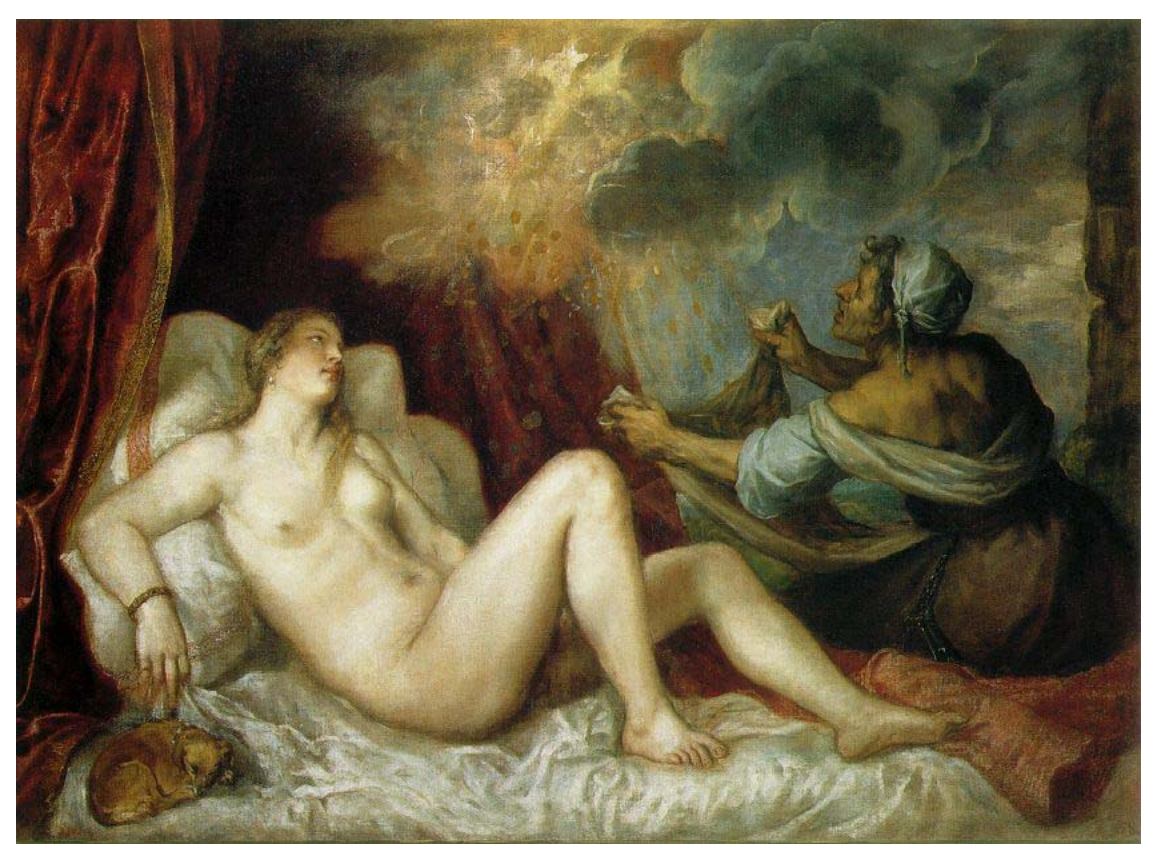

Figura 10 - Dânae, 1553 de Ticiano Vecellio

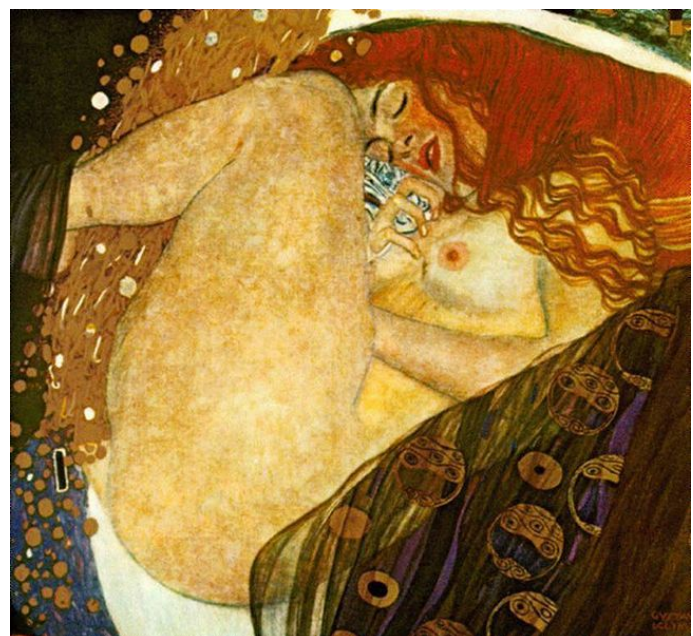

Figura 11 - Dánae, 1907/1908 de Gustav Klimt

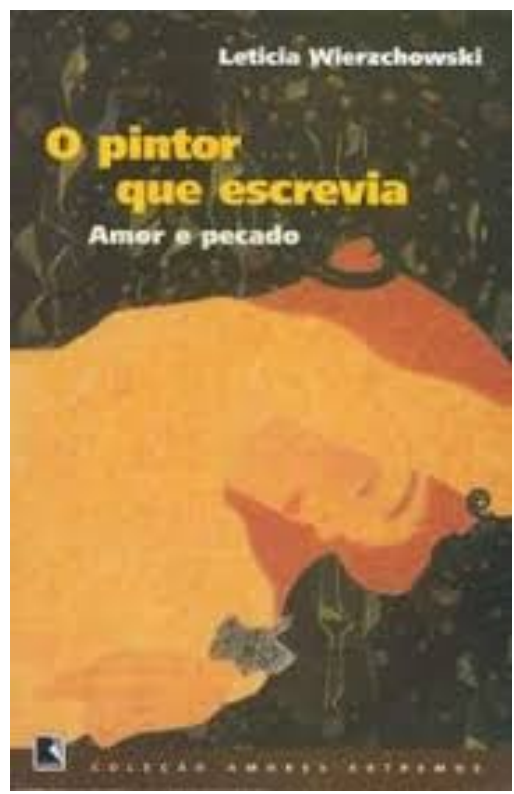

Figura 12 - Capa de O pintor que escrevia

Contrária à pose iconográfica de exposição do corpo feminino, como ocorre no quadro de Ticiano, Schiele dispõe um corpo em posição recolhida, quase fetal, semelhante a de seu mestre, Gustav Klimt, que numa 
composição de teor bastante erótico, quebra a placidez e a passividade típica das musas e representa uma mulher que se toca e em estado de pleno gozo. Schiele, menos explícito, opta pela representação de um corpo com poucos contornos, limitado principalmente pelo contraste do fundo.

Um ser identificável como mulher apenas da cintura para cima, parece transfigurado da cintura para baixo; amputado o corpo debruçado assemelha-se a um grande embrião, que na obra de Klimt aparece multiplicado e como um adorno de uma espécie de manto (Figura 11). Recolhido e amorfo é um corpo que beira à abjeção. Seguindo o pensamento de Butler, para quem o abjeto está no não respeito à lógica imposta pela matriz de inteligibilidade, aspecto aqui já discutido, trazer a representação de um corpo que desestabiliza tal coerência seria uma transgressão a se considerar. Porém, apesar de estampar a capa, o quadro de Schiele aparece, tal como em outras obras da coleção, recortado. Não coincidentemente apenas a parte plasticamente inteligível é utilizada. A exclusão, como consequência direta de quem ou o que desestabiliza o jogo imposto pela matriz, é, então, recorrida e os interditos da narrativa são, assim, estendidos e reiterados para e na capa.

\subsection{Amor e perda}

Se boa parte das vezes o discurso da perda amorosa constrói-se a partir de floreios de lamentações, pedidos de perdão ou acusações acompanhadas de vitimização ou promessas futuras de seguir em frente, a narradora abandonada de Marilene Felinto, denominada Obsceno abandono (2002), numa fala despudorada, encara seu sofrimento de forma crua. No lugar de antíteses e metáforas que tornem abstrato, floreiem seu sofrimento, toda dor é física, ganha corpo, é sentida na carne, sangra. As acusações voltam-se para ela mesma, que num ato de responsabilidade por seus sentimentos, arrepende-se de ter se enganado contra todas as evidências de um abandono certeiro, inevitável. E se o significado de vulnerabilidade provém de fraqueza, no relato da narradora, firma-se como um ato de coragem, mesmo que essa, para ela atrapalhe tanto quanto a covardia. 
Escrito quase todo na forma de monólogo interior, quase que num fluxo de consciência, com raciocínios interrompidos, frases que se repetem "De todas as pessoas que não me quiseram, Charles foi o pior" (OA, p. $11)^{25}$, como quem rememora mentalmente fatos, regata histórias, reconstrói diálogos e tenta explicar a si mesma, racionalizar sua situação de abandono, seus sentimentos, "mas em que lugar do cérebro fica, afinal o arrependimento?" (OA, p. 13).

Há um esforço consciente e empenhado por parte da protagonista na racionalização de seu sofrimento. Concomitante ao seu estado de enlouquecimento há sempre um gesto, uma observação que a situa no tempo e espaço, que lhe dá referências e argumentos.

Depois deste abandono, sei que tem dias que eu acordo com cara de louca. Mas em que lugar do cérebro fica, afinal, o arrependimento? Em que válvula, em qual espaço vazio se aloja essa doença?

Voltou ao varal, em prantos, hoje é sábado de noite, marco, para me localizar. (OA, p. 13)

A dor que a protagonista diz sentir sendo sobretudo física, a narradora faz do corpo sua estratégia de representação, a perda de que fala é totalmente corporificada, tudo é reconstituído, emana da e pela a personagem-narradora, o corpo e seus sentidos são mediadores de todas as suas ações e sentimentos, e é no embaralhamento dos dois que o texto ganha, mediante uma escrita sinestésica, sua expressividade.

Meu desequilíbrio fatal é outro..., é dor nos pavilhões desertos dos meus ouvidos, areia rangendo nos meus olhos... E eis que aqui estou eu remoendo um arrependimento, como quem mastiga grãos de pipoca e só escuta isso: sua própria mastigação, sua própria ruminação. (OA, p. 49-50).

O corpo delineado em Obsceno Abandono (2002) é um corpo concreto, que elimina secreções, que reage fisicamente, tem febre, perde a fala "depois do abandono, a primeira coisa que me acontece é que eu durmo mal e perco a fala" (OA, p. 20), mais do que palpável, o corpo é cru.

Em me sinto com uma pessoa fuzilada, que tivesse um buraco aberto um vazio violento - não um orifício destes como o da minha vagina, não. Uma dor. É seco o buraco, é a perfuração de um tiro, tiro de bala, bala de arma, de fuzil. Não, repito, não o orifício da minha vagina (hoje,

\footnotetext{
${ }^{25}$ As referências retiradas de Obsceno abandono serão citadas pela sigla OA, seguida do número da página.
} 
aliás, amortecido, amarfanhado e mofino como uma cadela doente). (OA p. 17)

Perder a fala é aspecto de muitas implicações. Para além de confirmar a hipótese de que todo o desabafo da protagonista dar-se-ia internamente e não de uma forma vociferada e verborrágica, é ampliar a dimensão e a veemência do abandono, do lugar que não só ele propriamente ocupa, mas da devastação que ele causa na vida da personagem, que tem sua habilidade de se expressar em alto e bom som por ele atingida.

O próprio arrependimento ultrapassa o sentimento de perda e é compreendido como "uma espécie de não reconhecimento de si mesmo, uma espécie de loucura" (OA, p. 38) que ela insiste em perguntar onde se instala,

Tivessem descoberto a minha doença, o meu vício, a minha dependência, a minha falta de lucidez, recomendariam logo um médico que jogasse um remédio no lugar do meu cérebro onde se aloja o arrependimento", (OA, p. 76)

... meu arrependimento é tanto que é físico, é dor nos pavilhões desertos dos meus ouvidos, areia rangendo nos meus olhos. Eu só me arrependo de ter aceitado um homem que não me queria. Eu só me arrependo de ter ficado de quatro, de ter me inaugurado para ele como uma virgem. (OA, p. 49)

Essa concretude do corpo vem ganhando cada vez mais força dentro das estratégias contemporâneas de representação do corpo, como bem afirma Maria Ester Maciel (2012):

enfocar o corpo fora das diretrizes impostas pelo mercado, de forma a explorar suas múltiplas potencialidades, enquanto uma realidade palpável e não apenas como uma imagem. Nesse sentido, trazem à tona uma noção de corpo que desvia da virtualidade para a concretude, da fixidez de sentidos para a mobilidade das sensações. Um corpo feito de carne, osso e vísceras, que sofre, adoece, tem prazer. (MACIEL, 2012, p. 78-79).

A escolha por essa concretude ganha ainda mais força e significado quando nos recordamos que Obsceno Abandono (2002) é escrito sob a condição de se falar de amor. É por meio dos sentimentos, que são sensações, que atravessam o corpo, que vai sendo construído aos poucos, à medida que a dor, o arrependimento caminha sob suas "pernas fracas que sustentam um corpo pesado e sozinho" (OA, P. 56), ascende para sua 
vagina "hoje aliás, amortecida, amarfanhada e mofina"(OA, p. 17), invadindo e compondo quase que parte a parte o todo do seu corpo. Mas essa concretude, como estratégia, seria imune à perspectiva voyeurística que transforma constantemente a anatomia feminina em um corpo-objeto? Falar de orifícios, secreções, despojar o corpo de toda noção de sacralidade e exibi-lo como um material qualquer é uma estratégia válida no questionamento do corpo como imagem histórico-social e psicologicamente construída?

Compreendendo o corpo como um artefato cultural, discursivamente construído, acredito que tornar visível o que estava sendo invisibilizado seja uma prática transgressiva válida, dessa forma, expor, assumir um corpo feminino, desafiando ideais de corpo perfeito, reconhecendo sua realidade concreta, fazer do grotesco ferramenta da construção de, como salienta Mary Russo (1986 apud WOLFF, 2011), alguns corpos, em certos contextos e espaços possa ser, sim, uma manobra que imunize o corpo feminino à incorporação pelo olhar que o reduz à objeto, numa ação de desidentificação, desestabilizando ideais em torno da ideia de um corpo feminino.

Em seus estudos sobre o grotesco feminino, Mary Russo (2000) o define a partir de prerrogativas bem próximas aos estudos de Butler sobre os corpos abjetos. É como um desvio à norma, "um espaço de risco e abjeção" (2000, p. 25) que ela o delimita e o aplica em suas investigações acerca do corpo feminino. Todavia, apesar de uso do grotesco oferecer uma espécie de armadura para o corpo, e o tratamento deste em Obsceno abandono (2002) seja até certo ponto destoante da norma, outros aspectos, não tão alheios a ele, não escapam do alcance dessa.

Trancafiada entre quatro paredes, inominada, descrita e reduzida por suas desventuras amorosas, a personagem de Obsceno abandono (2002) reitera muitas limitações interpostas a um ideal de feminino. Embora encare suas dores de forma crua e enxergue seu corpo a partir de aspectos considerados nada nobres e com isso dê a ele uma espécie de armadura, seu usufruto permanece masculino. No ato sexual, é o homem quem inaugura, abre, toma conta de seu corpo: 
Eu me sinto uma mulherzinha com um sexozinho que você abriu, foi abrindo, cada dia mais um pouco, às vezes me machucando, para achar o grelozinho recolhido e murcho lá dentro [...] Um buraquinho gosmento lá embaixo, é o que me sinto, um buraquinho por onde você se enfiou todo e gemendo". (OA, p. 34-35)

É como um talho, aberto por um homem, que ela encara sua vagina, "minha própria vagina é um talho aberto, um corte, uma fenda que abriram e que ele reabriu" (OA, p. 38). E ainda que a protagonista apareça como sexualmente liberada, e até diga se masturbar, assim que conhece e se apaixona por Charles, antes de transar com ele pela primeira vez, numa tentativa de purificação decide isolar-se de qualquer contato humano, "E eu resolvi passar o dia seguinte sozinha, só para me preservar e poder me entregar a você como se fosse pela primeira vez, como se ninguém tivesse me tocado antes, me visto, me olhado, como se eu fosse um nascimento."(OA, p. 52). Insistir nesse poder inaugurador e por consequência possuidor do pênis é manter-se presa a poderosos preceitos que nos aprisionam a referenciais masculinos e fazem da nossa sexualidade secundária, ao ponto de na narrativa ser equiparada a um momento originário.

A recusa da maternidade é outro aspecto suscitado na narrativa que a princípio, por ferir um dos pontos de maior significação social das mulheres, mostra-se como uma evidência na contraposição do jogo que envolve nossa inteligibilidade social, como afirma Navarro-Swain (2007):

[...] procriar, reproduzir a espécie passou a significar socialmente o feminino e esta significação social chama-se maternidade. Por um lado, a maternidade é louvada e incensada, objetivando-se na figura da mãe; por outro, torna-se uma fatalidade, na medida em que deixam de ser mulheres a imensa legião daquelas que não querem ou não podem ter filhos; perdem sua inteligibilidade social e alinham-se na fileira dos excluídos. A mãe é o modelo de mulher, a mulher no singular, uma figura fractal, que reproduz infinitamente a mesma imagem,. reduzida a um sentido unívoco de ser. (NAVARRO-SWAIN, 2007, p. 204)

Para uma narrativa tão centrada no corpo, refutar um discurso que tem nos órgãos reprodutores sua maior força e legitimação é gesto de grande relevância. Todavia as justificativas da recusa parecem fazer uso de velhos termos que empurram nossos corpos para as velhas dicotomias:

Ele: 
- O que você quer comigo? Filhos?

Eu, chocada:

- Filhos? Você sabe muito bem que não quero filhos. Jamais vou ter um filho. Filhos fazem duas exigências básicas, a que sou incapaz de corresponder. Primeiro: amor. Filhos exigem amor. Segundo: dinheiro. Não tenho dinheiro, não tenho herança. Quanto ao amor, você está certo. Duvido até hoje da minha capacidade de dar, de receber. Danese! [...] Não quero ter um filho com você. Filho não é curativo para a solidão de ninguém. Pode inclusive significar mais solidão. $O$ que me apavora é a perda. A minha é uma opção racional, essa de não querer ter filhos. (OA, p. 72)

Mesmo que nomeie a maternidade como uma opção e não um destino, a necessidade de adjetivá-la como uma opção racional nos faz pensar na recusa como um gesto forçado, como uma espécie de justificativa-mor diante do peso da fatidicidade da maternidade na vida de uma mulher.

É de forma visceral, erótica, às vezes pornográfica, que Marilene Felinto constrói sua narrativa de abandono, que recebe como ilustração da capa o quadro Undine (fig. 14), do pintor pós-impressionista, Paul Gauguin. Conhecido pelo uso de cores intensas e dono de um traço bastante característico, Gauguin teve sua estética movimentada pela necessidade de libertar a pintura de padrões formais; como defensor da pintura pela memória, como aponta Giulio Argan (2008), Gauguin pinta quadros sem relevo e profundidade e faz da cor seu principal instrumento de expressão. Em Undine, encontramos a imagem de uma mulher envolta por um mar verde revolto, o qual preenche todo o fundo da tela, e que contrasta com o vermelho (sua cor complementar) do cabelo, que também é utilizado nas letras do título principal da obra. Essa mulher é Undine, uma espécie de ninfa das águas da mitologia nórdica, que teria o poder de reger as ondas. 


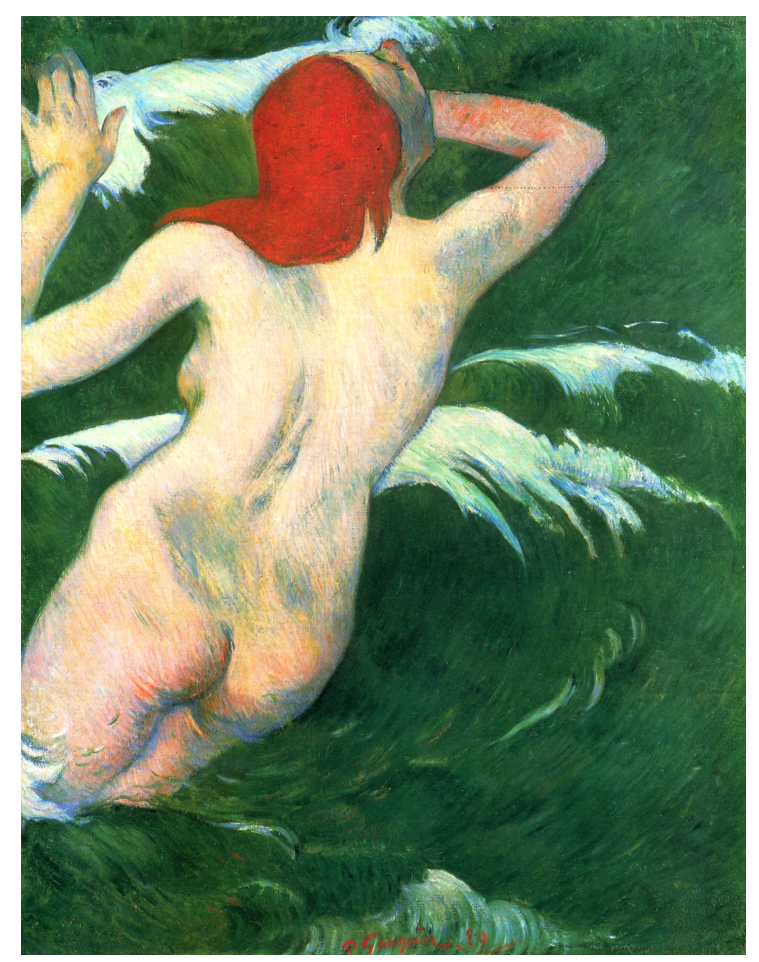

Figura 13 - Undine (1889), de Paul Gauguin.

Figura 14 - Capa de Obsceno abandono

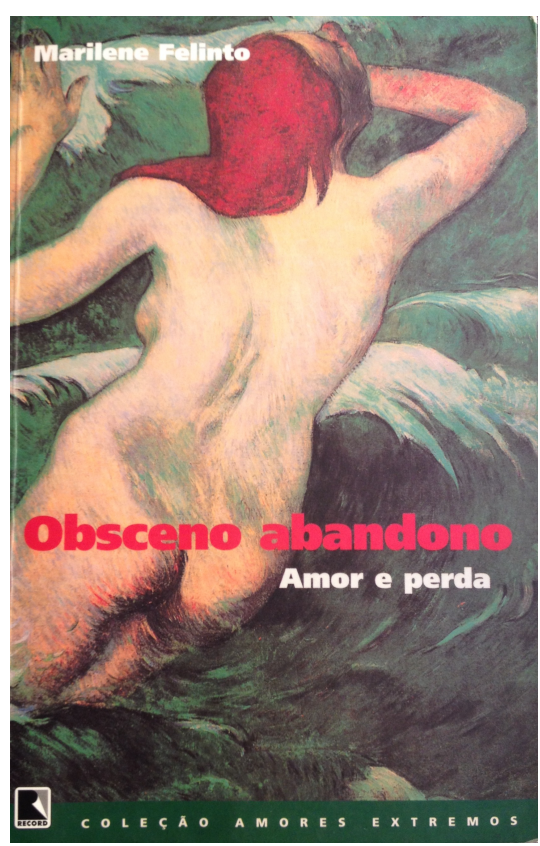

Há duas versões acerca do mito de Undine, a primeira conta que como ninfa, Undine seria imortal ao menos que um dia se apaixonasse por um mortal e com ele tivesse um filho, assim acontecendo sua imortalidade seria perdida. Ela se apaixona, casa-se e seu marido lhe promete que, enquanto ele estivesse acordado, cada suspiro seu seria testemunha do seu amor. Mas Undine começa a envelhecer assim que dá à luz ao seu filho, e com sua beleza se desvanecendo seu marido começa a perder o interesse nela. Um dia Undine o encontra com outra mulher e o almadiçoa dizendo que, como ele havia lhe prometido a fidelidade de cada suspiro, enquanto ele estivesse acordado ele teria sua respiração, mas assim que caísse no sono, assim como esqueceu do amor que sentia por ela, ele se esqueceria 
de respirar. Vencido pela exaustão, o marido de Undine cai no sono e morre. Numa segunda versão (do alemão Friedrich de la Motte Fouqué, de 1811), o esposo de Undine a abandona e ela volta para o mar, mas não dando-se por vencida, volta e beija seu esposo Ihe tirando a vida.

O abandono seja de interesse ou o propriamente físico parece ser o elemento de conexão pensado para ligar capa e narrativa, tanto a Undine de Gauguin como a personagem de Felinto parecem estar submergidas por um misto de controle e descontrole ocasionado pelo abandono. Undine que, ao mesmo tempo parece reger o movimento furioso das ondas, aparenta estar prestes a ser engolida por elas, como percebemos no movimento dos braços, que nos confundem, podendo ser interpretado como um gesto de comando, como também de proteção contra algo ameaçador.

\subsection{Amor e desacerto}

Solo feminino (2002), romance da escritora Lívia Garcia-Roza, narra a história de Gilda, jovem de 26 anos, que mantém um caso com um homem casado, José Júlio, mora com a mãe, que já quase não escuta, o que dificulta a já parca comunicação entre as duas, e um tio depressivo, Lili. A trajetória de Gilda é marcada por sua incessante, destrambelhada e infrutífera busca pelo orgasmo, que em sua vida torna-se sinônimo de felicidade e acaba mostrando-se tão escapável e abstrato como essa. Porém, o desacerto de Gilda não se limita a questões sexuais, faz-se presente, também, e talvez até principalmente, na sua relação familiar, que parece sempre interpor-se em suas escolhas, comportamentos, decisões.

Apesar de presente em outras obras da coleção, como Recados da lua (2001) e Para sempre (2001), a família em Solo feminino (2002) ganha espaço e protagonismo na trama. A relação entre mãe e filha é a mais explorada na narrativa. Como representante e defensora de um modelo tradicional de família, a mãe é exposta e questionada por seu embate com Gilda que, na sua inadequação no mundo, evidencia falhas e incongruências pregada pelo modelo assumido pela mãe.

Como uma mãe conservadora, fruto de uma educação de comedimentos e restrições, a mãe de Gilda acredita fracassado na 
educação de sua filha mais nova, que contrário a suas duas outras filhas, Geralda (Dadá) e Geny (Nina), não segue em nada as designações da mãe. Gilda bebe, usa roupas provocantes, chega tarde em casa, namora um homem casado, rejeita a maternidade e a construção de um projeto de família. Comparada às irmãs, que apesar de estarem em relacionamentos ruins, Dadá vive um casamento infeliz com um marido infiel e Nina sempre acometida e fragilizada pelas instabilidades de seu relacionamento, frequentemente recorre à casa e à mãe, Gilda, por contrapor-se às expectativas de sua mãe, considera-se um estorvo:

Conversei um pouco com mamãe, quer dizer, ouvi-a enveredar pelo seu assunto predileto: nós, filhas - desde o começo. Dizia que Dadá sim, casou bem, está feliz, tranquila, com o marido e os filhos, nada lhe falta; Nina já não teve a mesma sorte, a fixação em Sérgio não é nada boa, mamãe acha que está obsedada. E eu sou uma fonte perene de preocupação. (SF, p. 49) ${ }^{26}$

Um retrato fracassado de família é o representado em Solo feminino (2002). A solidão da mãe, que já surda, pouco ou nada consegue interagir e se comunicar, a desilusão das irmãs são alguns dos indícios de falibilidade desse modelo familiar que, por toda narrativa, num duplo gesto, como aponta Virgínia Leal (2010, p. 73), é reproduzido, sobretudo pela figura da mãe, e desconstruído, pelas incompatibilidades de Gilda: "A família mostrada pela escritora é um local tanto de reprodução da tradição quanto de seu questionamento, movido pelo efeito de paródia e criação de estereótipos através de personagens por vezes caricaturais".

Pela predileção em explorar as relações, sobretudo familiares, como disserta Leal (2010) sobre as obras de Garcia-Roza, a autora concentra suas narrativas principalmente nos limites do espaço doméstico. Não descrita em detalhes físicos específicos é a família quem delineia esse espaço da casa, que em nada configura-se como um lar acolhedor e reconfortante, aparece, tal como as relações ali mantidas, de forma hostil e atormentadora, constituindo-se assim como mais um elemento de desordem e desacerto da narrativa. É como uma moldura que circunscreve a trama que Edma Góis (2013) trata o espaço doméstico em sua análise de Solo

\footnotetext{
${ }^{26}$ As referências do romance Solo feminino serão citadas pela sigla SF, seguida do número da página.
} 
feminino (2002). Mais que um elemento de decoração e proteção, a moldura quase sempre delimita espaços, protege contra o externo; dessa forma, na narrativa, a casa, mais que ambientar, representa o modelo tradicional de organização e vivência familiar, questionado por Gilda, que, ao transitar entre os dois mundos, salienta suas disparidades.

Sentido em muitos aspectos, os desacertos têm sua fonte primária na falta de comunicação. Com uma linguagem afoita, de períodos curtos e pensamentos interrompidos, a fala de Gilda é caótica e fraturada, e ainda que existam diálogos na narrativa, a troca de palavras se dá de forma deficiente. A falha de comunicação entre Gilda e a mãe, que têm nas palavras cruzadas o mediador das tentativas breves $e$ falhas de aproximação, é um dos indícios do fracasso do modelo nuclear burguês de família.

Encontrei mamãe, revistinha de palavras cruzadas no colo; logo ao me ver, perguntou se eu sabia o que era aspirante, onze letras. Pretendente, respondi. Esperei que ela acabasse de escrever, sorrindo, e contei que saíra do emprego... Mamãe continuava com olhos grudados na merda da revistinha e, antes que eu continuasse a falar, perguntou se eu sabia o que era pavorosa, horrorosa. Tétrica, respondi, e disse também que ela precisava exercitar seus neurônios, não eu. Chateada, ela fechou a revistinha, perguntando o que eu queria que ela dissesse. Que eu tomava as decisões e depois vinha me comunicar. (SF, p. 74)

Essa busca pelas palavras, metaforizada pelas palavras cruzadas, atravessa todo o romance, que escrito com uma linguagem cotidiana, entrecortada pelas muitas distrações de Gilda, camufla-se atrás de uma superficialidade que, na verdade, é apenas aparente, pois discute e, principalmente, faz críticas a modelos de vida e aos problemáticos papéis de gênero. Como exemplo, temos Gilda que, num primeiro momento, pode ser reduzida a esse ideário de mulher moderna, frequentemente trazido pela chick lit, uma mulher urbana, profissional, independente, com uma vida sexual e amorosa ativa, diversificada e permanentemente em crise. Porém, ao acompanharmos a trajetória de Gilda na busca de um orgasmo, o que teoricamente aparenta transgressão, mostra-se como mais uma poderosa ferramenta de controle e adestramento das vontades e desejos de nós, mulheres. 
Conjuntamente com as relações familiares, o sexo é um dos eixos centrais da narrativa, aparecendo como principal mediador das relações que Gilda estabelece com seus companheiros, ou mesmo com os homens que ela imagina poder vir a ser, e com seu próprio corpo, sempre visto voyeristicamente, de uma ótica erótica, "sou uma mulher magnética, atraio todos para o meu âmbito; meu arrecife, minhas curvas setentrionais..." (SF, p. 56), característica ainda sublinhada pela própria narradora na escolha de suas roupas: "Demorei para escolher o que usar, quase todas as minhas roupas são curtas, leves e transparentes; é o que importa, construir uma ilusão de nudez." (SF, p. 18), "vestida como sempre, pouco pano, muito corpo." (SF, p. 69).

Apesar de atender a vários aspectos do estereótipo de beleza feminina e se vangloriar por isso, há uma disparidade entre esse corpo sexualizado e atraente e o exercício de sua sexualidade, que se mostra insatisfeita. Relembrando o conceito de dispositivo da sexualidade trabalhado por Foucault, que diz respeito a veículos e ferramentas presentes nas mais diversas instâncias que moldam nossos corpos e manipulam nossos desejos e práticas amorosas e sexuais, trazer uma personagem que inviabilize a eficácia desse dispositivo é gesto de bastante relevância. Considerando que a maneira de se viver a sexualidade é afetada por inúmeros fatores, como gênero, raça, etnia, classe social, e que o prazer, os desejos sexuais são promovidos, regulados pelo próprio discurso que é construído a partir de inúmeros dispositivos, como sustenta Foucault, que nos alcançam em nossas dimensões mais íntimas.

Se o corpo de Gilda responde afirmativamente a uma série de preceitos, estes entram em choque com opiniões e atitudes da protagonista, fora o inalcançável orgasmo, o comportamento descomedido e o repúdio pela maternidade corroboram com mais esse desacerto. Porém, ainda sob o domínio do dispositivo da sexualidade, o corpo de Gilda aparece delineado e sujeitado a repaginadas sujeições. Gilda, como personagem contemporânea, tem sua sexualidade vivida sob o imperativo do gozo, como salienta Virgínia Leal (2010), uma vez que o sexo, como defendido por Foucault, passou a ser peça-chave na busca pela totalidade e inteligibilidade de nossas identidades e corpos: 
Toda a experiência corporal de Gilda é vinculada à atividade sexual e à sua impossibilidade de prazer. Soterrada pelos efeitos dos discursos sobre sexualidade, seu corpo e seu comportamento, Gilda, de Solo feminino, é a personagem que mais dialoga com a ideia de "falsa" liberação sexual, travestimento de uma nova forma de controle sobre os corpos femininos. (LEAL, 2010, p. 76)

Se inicialmente, os dispositivos da sexualidade funcionaram de modo opressor, cheio de restrições e interdições sutilmente instituídas, hoje, o discurso que vende uma liberação sexual mostra-se tão à mercê de interesses de controle dos corpos femininos quanto no momento em que o imperativo imposto era o da castidade a mulheres, sendo apenas mais uma forma refinada de circunscrever corpos, desejos e práticas sexuais das mulheres, o que faz de Gilda produto dessa nova lógica, porém, Lívia Garcia-Roza, talvez por perceber a força e a presença da ideologia de gênero presente nas personagens e situações que representa, traz personagens fracassadas em muitos aspectos, falhas de comunicação, a própria busca frustrante por um orgasmo, evidenciam problemas na representação dessa mulher, gera um incômodo, e incomodar parece sempre ultrapassar, mesmo que pouco, o discurso patriarcal que tanto nos educou para sermos agradáveis, dóceis, anjos do lar.

llustrada pela obra Femme qui tire son bas (fig. 9) do pintor francês Henri de Toulouse-Lautrec, que ficou famoso por registrar o cotidiano do submundo de Montmartre, tendo artistas, dançarinas, prostitutas, cafetões como figuras emblemáticas de sua obra, Solo feminino (2002) traz na capa um corpo feminino, seminu, despindo-se, com poucas intervenções de cor e desenhado sob traços breves, inacabados que evidenciam o imediatismo do esboço e ressaltam uma das principais buscas do pintor francês, a captura do instante. Na brevidade dos traços que o movimento é apreendido, ao olharmos para o desenho é fácil imaginar o traçado rápido e constante de Lautrec no momento em que observava e já tentava imprimir na folha os instantes que dariam a sua obra movimento e, consequentemente expressão. 

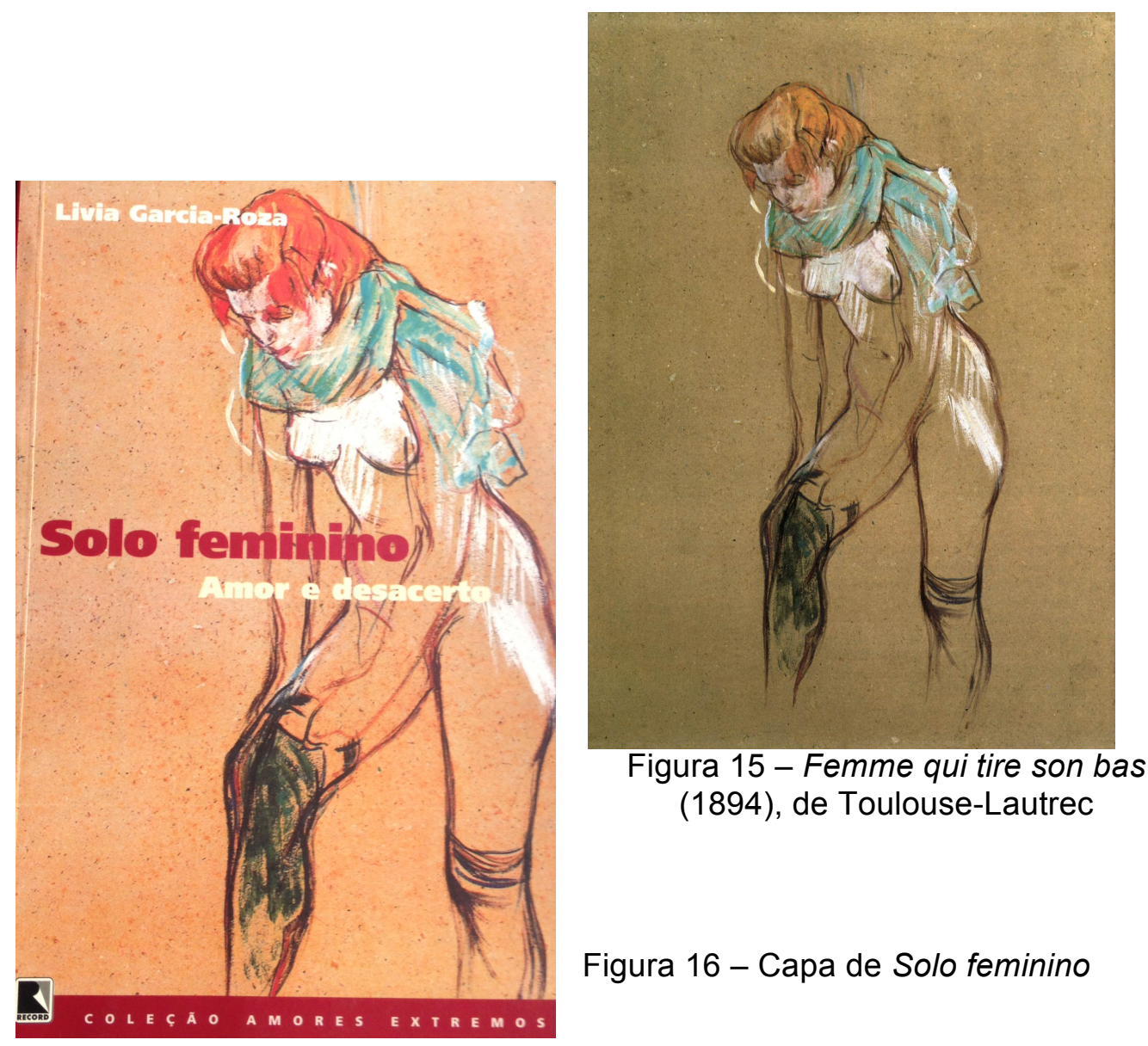

A mulher cabisbaixa que, ali, desveste sua meia é representada de forma mais humana do que propriamente bela, num gesto banal, mas que pode ser significado de várias formas, ainda mais quando ampliamos nosso olhar para toda a obra de Toulouse-Lautrec, que, como afirma o teórico da arte Giulio Argan (2008), não enxerga a atividade do artista como a de criação de um objeto acabado, um quadro, mas um trabalho que tem o poder de se desdobrar, numa série de desenhos, gravuras, pinturas, formando uma espécie de álbum que pode ser lido assim como se lê uma coletânea de poesias. É como uma obra permanentemente aberta, que deve ser repensada e continuada em produções próximas que Lautrec centra seu fazer artístico.

Dessa forma, trago mais duas obras de Lautrec, produzidas no mesmo ano, L'Inspection médicale (fig. 11) e Rue des Moulins (fig. 12), ambas as obras se assemelham bastante com a ilustração aqui analisada, partilham não só de cores, disposições e temática, como as narrativas 
vindas junto a elas. Nelas há duas mulheres, seminuas, enfileiradas, dispostas de forma bastante natural, sem conotação erótica ou lasciva, (o que é uma preocupação constante na obra de Lautrec, que buscou representar o espaço do cabaré sem máscaras, glamour, mas os momentos da vida diária das prostitutas) e como nome de uma das obras mesmo sugere, preparam-se para o exame médico constrangedor que se dava de tempos em tempos para lhes atestarem do acometimento ou não de alguma doença ou mesmo gravidez.

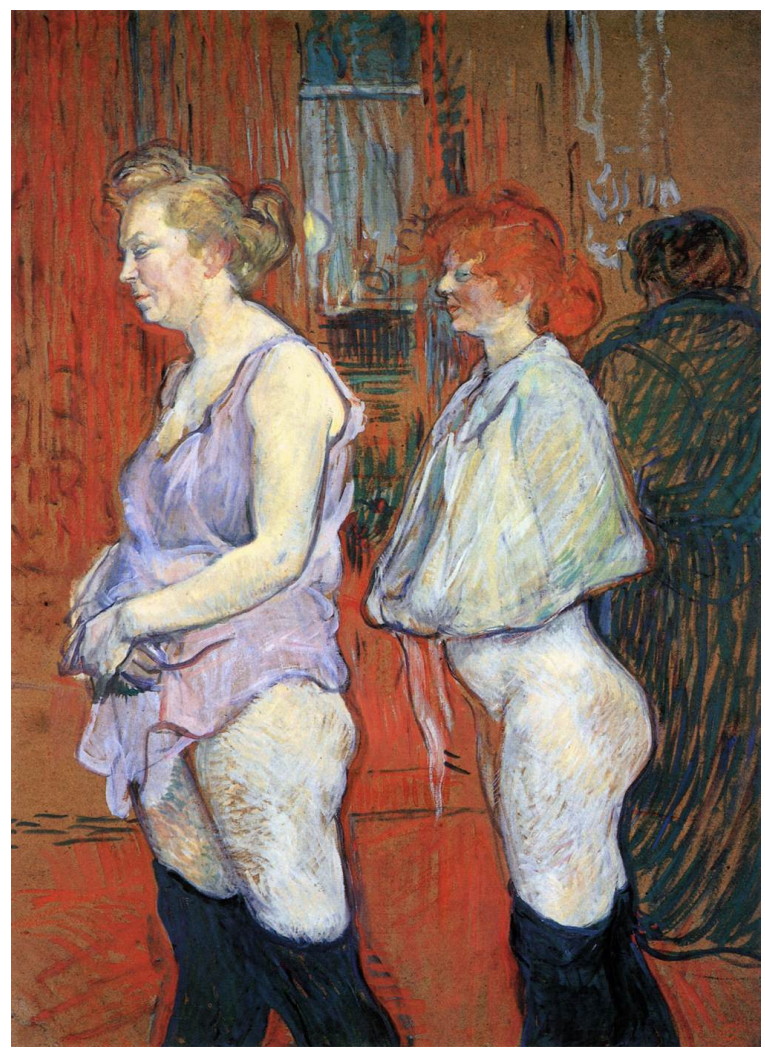

Figura 17 - L'Inspection médicale (1894), de Toulouse-Lautrec

É um cabaré à luz do dia o representado por Lautrec. Em contraste à atmosfera noturna e inebriante típica na representação desse submundo da prostituição parisiense, o artista traz cenas e acontecimentos de forma ordinária, representa um mundo, ainda que apartado e marginal, rotineiro. As disparidades sublinham-se quando olhamos para quem habita tal espaço. Tal como o espaço recebe um tratamento discordante do esperado, o corpo feminino, ali presente, semi-despido sem melindre ou cerimônia, prestes a ser usado, examinado, tem sua beleza posta em contraste com o exercício de sua sexualidade. Em tese aqui já citada, Edma Góis (2013), igualmente, expande seu olhar para a análise da capa de Solo feminino (2002), "mais uma vez, põe a beleza de um corpo feminino em choque com uma 
sexualidade não satisfatória está na imagem da capa do livro" (GÓIS, 2013, p. 96), e aponta a reincidência da discrepância entre temática e seu tratamento, entre o corpo e seu usufruto.

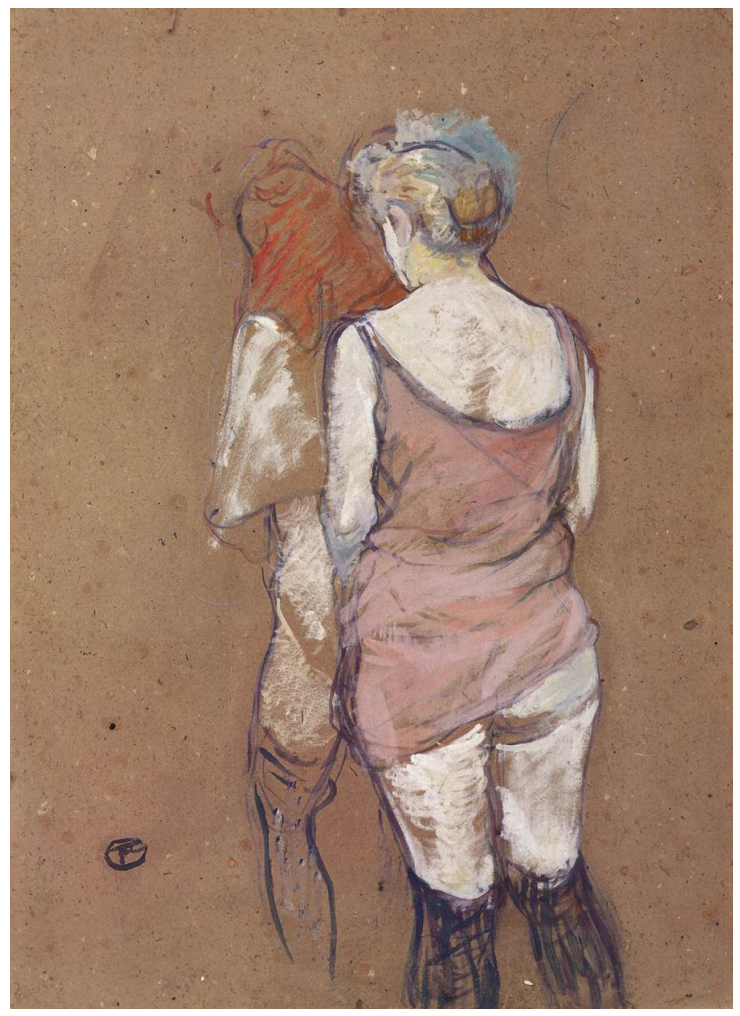

Figura 18- Rue des Moulins (1894), de Toulouse-Lautrec 


\section{Certezas provisórias ${ }^{27}$}

Pensar uma coleção é inevitavelmente fazer escolhas. Temáticas, estéticas, autorais, seja de qual ordem forem, todas elas carregam em si posicionamentos e ideologias. É no que há por trás do projeto da coleção Amores Extremos, no que a sustenta e viabiliza que busquei focar meu olhar e minhas análises. Com a ambição de enxergar o projeto como um todo, expandi meu olhar para além do corpo do texto e procurei igualmente nas capas pretensões de caminhos e interpretações eleitos pela coleção. Se como afirma Chartier, o livro sempre buscou instaurar uma ordem de decifração, ao prescrever caminhos e, assim, cercear compreensões; decifrar o roteiro instilado pela coleção foi o que propus fazer.

Frequentemente pensado por perfis de leitores e leitoras e alimentado por demandas, o formato coleção notabiliza a presença dos agentes envolvidos na produção de um livro e sublinha escolhas e representações presentes na coleção. A Amores Extremos, pautada nos recortes de autoria feminina e temática amorosa, suscita, desde a escolha de seus recortes, muitas hipóteses na motivação de sua aparição no mercado editorial brasileiro. Pensar que as escritoras, que têm a marca de seu gênero sublinhada pela proposta da coleção, por serem mulheres, estariam habilitadas a falar do amor, talvez, seja a primeira das muitas indagações que possamos nos fazer ao nos depararmos com tal coleção. Mas ao considerar que por trás dessa suspeita há um jogo construído a partir de uma lógica binária, sustentada na diferença entre masculino e feminino, que como afirma Nelly Richard, está longe de ser uma diferença como outra qualquer, pois ela estrutura toda uma economia discursiva de simbologia da representação sexual e social, agenciando, assim seus respectivos significados, me vi obrigada a desmembrar tais estruturas e associações na busca de comprovação das muitas hipóteses levantadas.

A começar por sua orelha de apresentação, a coleção já nos dá indícios e justificativas de sua proposta e escolhas. Nela, a coleção é

\footnotetext{
27 Termo utilizado por Guacira Lopes Louro (2003) em seu texto "Uma epistemologia feminista"; a autora faz uso da expressão ao discorrer sobre o constante movimento de autocrítica que o pensamento feminista deve adotar.
} 
apresentada como uma "demonstração da magnitude da presença feminina na literatura brasileira", e apesar de já na frase seguinte afirmar que tal fato não necessita de comprovações, justifica seus recortes no "tom particular" que as escritoras têm conseguido imprimir às questões humanas. Imbricado a esses apontamentos está não só a necessidade de responder à velha pergunta que põe em dúvida a existência de uma literatura produzida por mulheres, como a confirmação de uma especificidade que singulariza e conecta as escritoras e, por consequência, as fazem competentes na execução de tal tarefa.

Ao ter como mote uma espécie de denominador comum entre as mulheres, a coleção tem, inevitavelmente, como pressuposto, um conceito de mulher, ou ainda de um feminino. Arquitetado e alimentado por um jogo responsável por promover a estabilidade da estrutura binária dos sexos, o feminino, promovido por inúmeras práticas reiterativas, como a literatura, ganha força e ilusão de naturalidade na repetição de sua representação. E ainda que na proposta da coleção esse feminino surja em obediência à estrutura que hierarquiza e viabiliza os indivíduos em relação ao seu sexo, as sete escritoras, previamente apresentadas à proposta da coleção, minimamente conscientes das possíveis implicações contidas na tarefa de falar de amor, a partir de um lugar de fala assinalado pela marca de gênero, poderiam, nas infinitas possibilidades que a literatura oferece, problematizar tal lógica.

Duvidar do jogo pelo qual se é pensado o feminino é o que interpreto aqui como consciência feminista. Identificar representações que de alguma forma não o tomem como um termo auto-evidente e que apresentem quando não novas possibilidades, seus limites e incongruências foi um dos meus principais objetivos na análise da coleção. Mas, se inicialmente, presumi encontrar narrativas que me mostrassem, na promessa de abordar variadas vertentes e extremidades do amor, diferentes possibilidades de mulheres, que vivenciassem experiências amorosas de múltiplas formas, ao ler a coleção deparei-me com um repertório limitado e pouco ou nada transgressor.

Limitadas não só a um modelo de feminino, mas igualmente restritas a um universo inteligível de relações amorosas, as narrativas da coleção 
Amores Extremos repisam uma série de preceitos que reforçam os limites construtores desse ideal de feminino. Ao trazer relações majoritariamente heterossexuais, representar famílias presas a um modelo nuclear-burguês e fazer do amor, mais que figura central da narrativa, principal ambição da vida de suas personagens mulheres, que são descritas, medidas e principalmente cerceadas por suas relações amorosas. E mesmo quando há uma tentativa de opor-se a esse universo limitado de referências, como ocorre com a segunda leva de análise das narrativas, em que há a representação de amores interditos e fracassados, o dispositivo amoroso permanece vigoroso, comandante das ações e pensamentos das protagonistas.

Tal como as narrativas indicam escolhas e decisões de suas autoras no trabalho da proposta da coleção, aspectos paratextuais carregam o mesmo potencial. Sob a especificidade de ser pensada conjuntamente, como um elemento de conexão e identificação de uma coleção, a capa mostrou-se, ao longo de minha investigação, aspecto emergente. Sem acesso ao processo de escolha das capas, busquei estabelecer vínculos entre essas e suas narrativas. Individualmente, em boa parte das obras, por similaridades ou contrastes nas abordagens e tratamentos, foi possível estabelecer algum tipo de diálogo. Coletivamente há um grande descompasso na própria escolha das imagens, ou mais especificamente, em seus produtores. Valerse de obras consagradas, de pintores homens, numa coleção que de alguma forma reivindica para si um selo de produção de mulheres é gesto bastante incongruente e inoportuno. O recorte efetuado em algumas capas aparece igualmente discutível. O corpo feminino, que nu, aparece em seis das sete obras da coleção, num gesto asséptico tem partes consideradas "obscenas" ou ainda sexualmente mais explícitas e agressivas retiradas de cena, aparece editado e como mais uma evidência dos assujeitamentos da coleção aos padrões de representação. Observa-se que a única pintura que não apresenta nudez é aquela que traz um casal, no caso obra de Marc Chagall.

Como quem se aproxima, em busca de detalhes, observa traços, pinceladas, movimentos de uma obra e depois dá passos para trás na busca de uma visão do todo, perfiz meu trajeto e análises da coleção. Dissecando narrativas e cotejando similaridades e disposições. Mas se expandir o olhar para as capas me possibilitou ter mais evidências na comprovação das 
hipóteses levantadas, foi preciso ultrapassar molduras e capas para compreender o projeto que perpassa e une as narrativas.

Diante de demarcações, contornos tão específicos, a coleção acaba por reforçar o que está dentro e automaticamente ressalta o que fica de fora. Teresa de Lauretis aproveita, em seu texto acerca do gênero, o termo cinematográfico, space-off, que demarcaria um espaço não visível, mas que poderia ser inferido a partir do que se é mostrado, ou ainda do que é sucessivamente excluído. Ao abrigo desse termo e da acepção de Lauretis proponho minhas leituras e análises. E se o space-off nos permite ver o que ele, por contraste, evidencia; como uma espécie de ponto cego que é, configura-se igualmente como um espaço possível de ação e resistência, uma possibilidade de ver e ler o mundo de uma outra perspectiva.

É como uma revitalização de uma antigo formato de coleção de mulheres para mulheres que a coleção Amores Extremos se configura. Erguida por demandas identitárias, a coleção reflete o que Nelly Richard nomeia de ilusão representativa, no sentido de ilustrar temas e conteúdos que buscam alcançar uma classe homogênea de leitores e/ou leitoras que, por sua vez, possam se reconhecer nas referências e revalidar o sentido comum de pertencimento de gênero: "Reconhecimento e identificação são as chaves tranquilizadoras, que colocam o leitor em comunicação com uma matriz de significação". (RICHARD, 2002, p. 152). Porém, apesar de reproduzir padrões, sugerir referências e identificações, há sempre "entrelinhas rebeldes" (RICHARD, 2002, p. 136) que podem desestabilizar tal lógica.

Judith Butler, no seu processo de desconstrução do sistema sexo/gênero, amplia o alcance do discurso em nossas vidas e além de afirmar que o sexo é tão construído quanto o gênero, acrescenta dois novos aspectos no que ela chama de "matriz de inteligibilidade": o desejo e a prática sexuais. Responsável por viabilizar nossas identidades, a matriz nos cobraria uma "coerência" entre nossos corpos, gestos e práticas. De forma similar, a coleção, mais que obedecer a lógica imposta pela matriz nas suas escolhas e recortes, tem no seu projeto editorial, (como a capa e a escolha de escritoras mulheres para falar de amor), uma visão superficial do que seja o sistema sexo/gênero, enfatizando a matriz de inteligibilidade. 
A capa como um veículo responsável por transmitir uma identidade visual à coleção, assim como nossos corpos, é solicitada a transparecer alguma informação a respeito da narrativa que carrega. Como aspecto primário da nossa identificação de gênero, o corpo, por possuir significados socialmente construídos, possibilita um reconhecimento imediato. A capa, sobretudo em uma coleção, além de sugerir interpretações e influenciar escolhas, evidencia um projeto. Corpo e capa são, assim, indícios possíveis de problematização, bem como a escolha de escritoras mulheres. Marilene Felinto, em entrevista ${ }^{28}$ sobre Obsceno abandono (2002), fala do seu incômodo em relação à proposta da coleção, pois diz não acreditar em uma literatura de rótulos, afirma que só aceitou a encomenda por amizade a Luciana Villas-Boas. Mesmo discordando da proposta da coleção, ela poderia ter escrito uma narrativa mais transgressora, nos termos das "entrelinhas rebeldes" de Richard (2002). Por mais que a escritora quisesse se afastar da ideia de um denominador comum para o conceito de autoria feminina, especificamente para falar sobre "amores extremos", sua narrativa ainda reitera, como já visto, limitações.

Quando me deparei com uma coleção com a promessa de tratar de Amores Extremos, esperei encontrar uma pluralidade de representações tanto de suas personagens quanto de seus relacionamentos. Porém, se os recortes - autoria feminina e temática amorosa - juntos, já me sugeriam algumas suspeitas, após análise de toda coleção, seus limites se estreitaram. Diante da potencialidade do tema, os livros, apesar de apresentarem tentativas relevantes de transgressão, (como a busca pelo prazer, a sexualidade na velhice, o lado grotesco da perda e incesto), terminam por frustrar suas próprias intenções. Retomando o conceito de space-off de Lauretis, pode-se a partir dos limites, dispor-se de leituras transbordantes e ambicionar afetos desmedidos.

28 PROGRAMA LITERATO. Marilene Felinto - Programa Literato. Disponível em: https://www.youtube.com/watch?v=PBe7H4pRUVo. Acessado em: 27 de abril de 2016. 


\section{Referências bibliográficas}

Obras literárias

AMARAL, Maria Adelaide (2003). Estrela nua: amor e sedução. Rio de Janeiro: Record. (Amores Extremos).

FELINTO, Marilene (2002). Obsceno abandono: amor e perda. Rio de Janeiro: Record. (Amores Extremos).

GARCIA-ROZA, Livia (2002). Solo feminino: amor e desacerto. Rio de Janeiro: Record. (Amores Extremos).

JOBIM, Helena (2001). Recados da lua: amor e romantismo. Rio de Janeiro: Record. (Amores Extremos).

MACHADO, Ana Maria (2001). Para sempre: amor e tempo. Rio de Janeiro: Record. (Amores Extremos).

SEIXAS, Heloisa (2001). Através do vidro: amor e desejo. Rio de Janeiro: Record. (Amores Extremos).

WIERZCHOWSKI, Letícia (2003). O pintor que escrevia: amor e pecado. Rio de Janeiro: Record. (Amores Extremos).

\section{Referências}

ARGAN, Giulio Carlo (2008). Arte moderna. $2^{\mathrm{a}}$ ed. Tradução de Denise Bottman e Federico Carotti. São Paulo: Companhia das Letras.

BAUMAN, Zygmunt (2004). Amor líquido: sobre a fragilidade dos laços humanos. Tradução de Carlos Alberto Medeiros. Rio de Janeiro: Zahar.

BOURDIEU, Pierre (1996). As regras da arte: gênese e estrutura do campo literário. Trad. de Maria Lucia Machado. São Paulo: Companhia das Letras.

BUTLER, Judith (2003). BUTLER, Judith. Problemas de gênero: feminismo e subversão da identidade. Rio de Janeiro: Civilização Brasileira.

BRANCO, Lúcia Castelo (1984). O que é erotismo. São Paulo: Círculo do Livro. (Coleção Primeiros passos).

CARRIJO, Silvana Augusta Barbosa (2008). Eros anunciado. In: PIRES, Maria Isabel Edom (Org.) Formas e dilemas: da representação da mulher na literatura contemporânea. Brasília: Editora Universidade de Brasília. 
CHARTIER, Roger (1994). A ordem dos livros: leitores, autores e bibliotecas na Europa entre os séculos XIV e XVIII ${ }^{e}$.Tradução de Mary del Priore, Brasília: Editora Universidade de Brasília.

(2002). Os desafios da escrita. Tradução de Flávia M. L. Moretto. São Paulo: Editora UNESP.

COLASANTI, Marina (1997). "Por que nos perguntam se existimos". In: SHARPE, Peggy (Org.). Entre resistir e identificar-se: para uma teoria da prátiva da narrativa brasileira de autoria feminina. Florianópolis: Editora Mulheres; Goiânia: EdUFG, p. 33-42.

DALCASTAGNĖ, Regina (2005). "A personagem do romance brasileiro contemporâneo: 1990-2004". Estudos de Literatura Brasileira Contemporânea, n. 26. Brasília, julho-dezembro, p. 13-71.

(2010). "Representações restritas: a mulher no romance brasileiro". In: Deslocamentos de gênero na narrativa brasileira contemporânea. DALCASTAGNĖ, REGINA; LEAL, Virgínia M. V. (Org.). São Paulo: Editora Horizonte.

DEL PRIORE, Mary (2006). História do amor no Brasil. 2a ed. São Paulo: Editora Contexto.

EL FAR, Adriana (2006). O livro e a leitura no Brasil. Rio de Janeiro: Editora Jorge Zahar.

ESCARPIT, Robert (1976). A revolução do livro. Tradução de Maria Inês Rolim. Rio de Janeiro: Editora Fundação Getúlio Vargas/ Instituto Nacional do Livro.

FAIRCLOUGH, Norman (2008). Discurso e mudança social. Tradução de Izabel Magalhães. Brasília: Editora Universidade de Brasília.

FOUCAULT, Michel (1979). Microfísica do poder. Tradução de Roberto Machado. Rio de Janeiro: Edições Graal.

(1999). Vigiar e punir. Tradução de Raquel Ramalhete. $20^{a}$ ed. Petropólis - RJ: Editora Vozes.

(1999). História da sexualidade l: a vontade de saber. Tradução de Maria Thereza da Costa Albuquerque e J. A. Guilhon Albuquerque. $13^{a}$ ed. Rio de Janeiro: Edições Graal.

FUNCK, Susana (2011). "O que é uma mulher". Cerrados, Brasília, n. 31, ano 20, p. 65-74.

GENETTE, Gérard (2009). Paratextos editoriais. Tradução de Álvaro Faleiros. Cotia, SP: Ateliê Editorial. 
GIDDENS, Anthony (1993). A transformação da intimidade: sexualidade, amor e erotismo nas Sociedades Modernas. Tradução de Magda Lopes. São Paulo: Editora da Universidade Estadual Paulista.

GIMENES, Thais Regina Pinheiro (2009). O trágico em Édipo Rei e Lavoura Aracaica: Leitura contrastiva. 2009. Dissertação (Mestrado em Literatura) Universidade Estadual de Maringá.

GÓIS, Edma Cristina Alencar de (2013). Cartografias dissonantes: corporalidades femininas em narrativas brasileiras contemporâneas. Tese (Doutorado em literatura) - Universidade de Brasília.

GROZS, Elizabeth (2000). "Corpos reconfigurados". Cadernos Pagu, Campinas-SP, n. 14, p. 45-86.

HALLEWELL, Laurence (1985). O livro no Brasil: sua história. São Paulo: T. S. Queiroz. Editora da Universidade de São Paulo.

LAURETIS, Teresa (1994). "A tecnologia do gênero", tradução de Susana Borneo Funck. In: HOLLANDA, Heloísa Buarque de (Org.). Tendências e impasses: o feminismo como crítica da cultura. Rio de Janeiro: Rocco.

LEAL, Virgínia Maria Vasconcelos (2011). "Deslocar-se para recolocar-se: amores entre mulheres em narrativas de autoria feminina". In: DALCASTAGNE, Regina; THOMAZ, Paulo C. (Orgs.). Pelas Margens: representação na narrativa brasileira contemporânea. Vinhedo-SP: Editora Horizonte.

(2011). "Editora Malagueta: Campo literário e identidade lésbica". Cerrados, Brasília, n. 32, ano 20, p. 387- 406.

LÉVY, Pierre (1993). As tecnologias da inteligência: o futuro do pensamento na era da informática. Tradução de Carlos Irineu da Costa. Rio de Janeiro: Editora 34.

LIMA, Susana M (2008). O outono da vida: trajetórias do envelhecimento feminino em narrativas brasileiras contemporâneas. Tese (Doutorado em Literatura) - Universidade de Brasília.

MACIEL, Maria Ester (2012). "Corpo, imagem e escrita". In: Revista da Universidade Federal de Minas Gerais. Belo Horizonte, vol. 19, n. 1 e 2, jan./dez., p. 76-91.

MAIA, Cláudia de Jesus (2011). A invenção da solteirona: conjugalidade moderna e terror moral em Minas Gerais (1890-1948). Ilha de Santa Catarina: Editora Mulheres.

MAINGUENEAU, Dominique (2011). O contexto da obra literária. Tradução de Marina Appenzeller, revisão de tradução Eduardo Brandão. 2 ed. São Paulo: Martins Fontes. 
NAVARRO-SWAIN, Tania (2003). Velha, eu? autoretrato de uma feminista. Labrys - Estudos Feministas (Edição em português. Online), v. 4, n.jul/dez.

(2006). "Entre a vida e a morte, o sexo". In: Labrys - Estudos

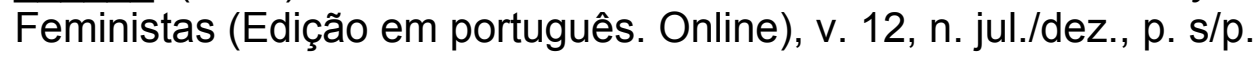

( 2007). Meu corpo é um útero? Reflexoes sobre a procriaçao e a maternidade. In: STEVENS, Cristina (Org.). Maternidade e feminismo: diálogos interdisciplinares. Florianóplois: Editora Mulheres, p. 201-247.

(2013). "A construção das mulheres ou a renovação do patriarcado" 2013. In: Labrys, - Estudos Feministas (Edição em português. Online) v. 23, p. s/p.

NEVES, Ana Sofia Antunes das (2007). As mulheres e os discursos genderizados sobre o amor: a caminho da "amor confluente" ou o retorno ao mito do "amor romântico"?. Estudos Feministas, Florianópolis, set/dez, p. 609-627.

PAES, José Paulo (1990). "Por uma literatura brasileira de entreterimento (ou: o mordomo não é o único culpado). In: $A$ aventura literária: ensaios sobre ficção e ficções. São Paulo: Cia das Letras.

PERROT, Michelle (2003). "Os silêncios do corpo da mulher". In: MATOS, Maria Izilda S. de; SOIHET, Rachel (Orgs.). São Paulo: Editora UNESP.

PISCITELLI, Adriana (2004). "Reflexões em torno do gênero e feminismo", em COSTA, Claudia de Lima; SCHMIDT, Simone Pereira (Orgs.). Poéticas e políticas feministas. Florianópolis: Editora Mulheres.

POWERS, Allan (2008). Era uma vez uma capa: História ilustrada da literatura infantil. Tradução de Otacílio Nunes. São Paul: Cosac Naify.

PROGRAMA LITERATO. Marilene Felinto - Programa Literato. Disponível em: https://www.youtube.com/watch?v=PBe7H4pRUVo. Acessado em: 27 de abril de 2016.

RICHARD, Nelly (2002). Intervenções críticas: arte, cultura, gênero e política. Tradução de Romulo Monte Alto. Belo Horizonte-MG: Editora UFMG.

ROUGEMONT, Denis (1988). O amor e Ocidente. Tradução de Paulo Brandi e Ethel Brandi Cachapuz. Rio de Janeiro: Editora Guanabara.

RUSSO, Mary (2000). O grotesco feminino: risco excesso e modernidade. Rio de janeiro: Rocco.

SCHWANTES, Cíntia (2007). "Narrativas de formação contemporânea: uma questão de gênero". In: Estudos de Literatura Brasileira Contemporânea, n. 30, julho-dezembro, p. 53-62. 
SHOWALTER, Elaine (1994). "A crítica feminista no território selvagem". Tradução de Deise Amaral. In: HOLLANDA, Heloísa Buarque de (Org.). Tendências e impasses: o feminismo como crítica da cultura. Rio de Janeiro: Rocco.

TODOROV, Tzvetan (1992). Introdução à literatura fantástica.Tradução de Maria Clara Correa Castello. $2^{\mathrm{a}}$ ed. São Paulo: Editora Perspectiva. (Coleção Debates)

WOLFF, Janet (2011). Recuperando a corporalidade: feminismo e política do corpo. In: MACEDO, Ana Gabriela; RAYNER, Francesca (Orgs.) (2011). Género, Cultura visual e Performance: antologia crítica. V.N Famalicão: Ed. Humus e Centro de Estudos Humanisiticos da Universidade do Minho.

WOOLF, Virgínia (2014). Um teto todo seu. Tradução de Bia Nunes de Sousa e Glauco Matoso. São Paulo: Tordesilhas.

YOUNG, Iris Marion (2003). "O género como serialidade: Pensar as mulheres como um colectivo social", Ex-Aequo - Revista da Associação Portuguesa de Estudos sobre as Mulheres, 8, p. 113-139 [tradução de Laura Fonseca e Marinela Freitas]. 